\title{
UTILIZAÇÃO DE DELINEAMENTO SISTEMÁTICO TIPO “LEQUE" NO ESTUDO DE ESPAÇAMENTOS FLORESTAIS
}

\author{
JOSE LUIZ STAPE \\ Engenheiro Agrơnomo e Engenheiro Florestal
}

Orientador: Prof. Dr. HUMBERTO DE CAMPOS

Dissertaçăo apresentada à Escola Superior de Agricultura "Luiz de Queiroz", da Universidade de Săo Paulo, para obtençã̃o do titulo de Mestre em Agronomia, Área de Concentraçăo: Estatistica e Experimentaçăo Agronómica.

PIRACICABA

Estado de São Paulo - Brasil Janeiro - 1995 
Ficha catalografica preparada pela Secao de Livros da Divisác de Biblioteca e Documentaçao - FCLQ/USP

\section{Stape, Jose Luiz}

$5793 \mathrm{u}$ Utilizaçăo de delineamento sistemático tipo "leque" no estudo de espacamentos florestais. Firacicaba, 1995.

Bsp.

Diss. (Mestre) - ESALQ

Bibliografia.

1. Analise de regressă 2. Estatistica experimental 3. Eucalipto - Espaçamento - Delineamento de experimen to I. Escola Superior de Agricultura Luiz de Queiroz, Piracicaba 


\section{UTILIZAÇĀO DE DELINEAMENTO SISTEMÁTICO TIPO “LEQUE” NO ESTUDO DE ESPAÇAMENTOS FLORESTAIS}

JOSE LUIZ STAPE

Aprovada em: $24 / 03 / 1995$

Comissão Julgadora:

Prof. Dr. Humberto de Campos

ESALQ / USP

Prof. Dr. Décio Barbin ESALQ / USP

Prof. Dr. José Carlos Barbosa FCAV / UNESP

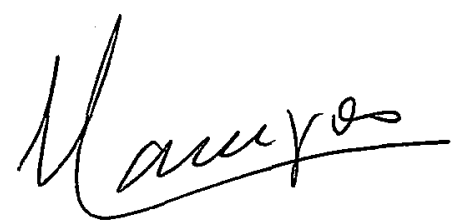

Prof. Dr. Humberto de Campos Orientador 
Aos meus pais,

Joubert e Lourdes

e

Aos meus irmãos,

Adalberto, Joubert, Helena, Ana, Angela, Teresa, Adão e José Roberto

D E D I C O

À minha esposa, Luceni Aos meus filhos, Thiago e Glauco 


\section{AGRADECIMENTOS}

Ao Professor Humberto de Campos, pela orientaçåo deste trabalho, de forma táo serena e encorajadora.

À Ripasa S/A Celulose e Papel, na figura de seus ex-diretores Engos Nelson Barbosa Leite e Edson António Balloni, pela oportunidade impar de ampliar os conhecimentos através das disciplinas do curso de Estatística e Experimentaçăo Agronómica da ESALQ.

Aos professores Dr. Décio Barbin, Dr* Clarice G.B. Demétrio, Dr.José Eduardo Corrente, e demais professores do Departamento de Matemática e Estatistica da ESALQ, pelo empenho na transmissăo de conhecimentos, prontidăo no auxilio e dedicação no lecionamento das disciplinas.

Aos professores Dr. Joăo Walter Simōes, Dr. Hilton Tadeu Zarate do Couto e Dr. Luiz Carlos Estraviz Rodrigues, e demais professores do curso de Engenharia Florestal da ESALQ, pelos ensinamentos básicos e aplicados da biometria florestal.

Ao professor Dr. José Carlos Barbosa, do Departamento de Ciéncias Exatas da FCAV de Jaboticabal, pela amizade, incentivo e auxílio na nossa formaçăo profissional.

À bibliotecária Marialice Metzker Poggiani pelo auxilio nas revisóes bibliográficas e no acesso ao acervo da biblioteca do IPEF.

Aos colegas de trabalho, Engos Florestais José Zani Filho e Carlos Alberto Guerreiro, pelo apoio nas horas mais atarefadas de nosso dia-a-dia.

Aos técnicos José Carlos Madaschi e Carlos Eduardo São Marcos, pelas criteriosas mensuraçóes e digitaçőes dos dados experimentais, base de todo este trabalho.

Aos calegas das disciplinas do curso de pós graduaçăo, Rosemeire (In Memorian), Elisete, Paulo Justiniano, Paulo Afonso, Rui, Pilar, Gilmar, Antônio, Samuel e Jomar, pelo companheirismo e alegrias compartilhados. 


\section{SUMÁRIO}

Página

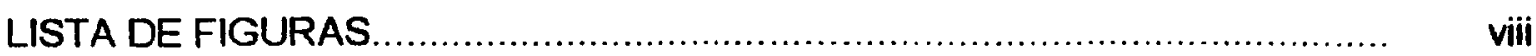

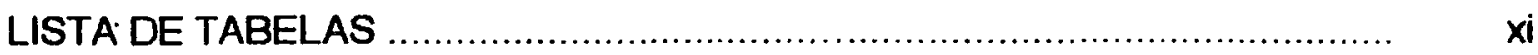

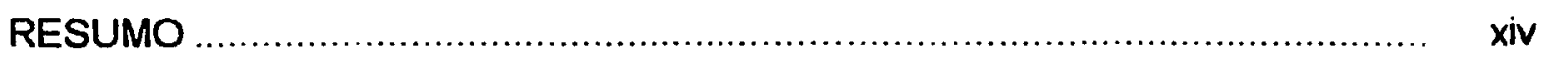

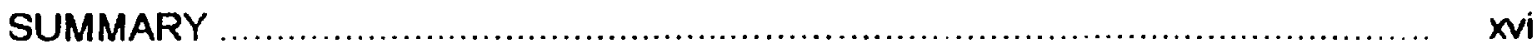

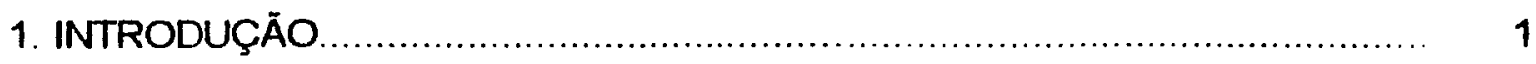

2. REVISÃO DE LITERATURA ....................................................... 5

2.1. Delineamentos Experimentais no Estudo de Espaçamentos Florestais...... 5

2.2. Delineamentos Sistemáticos com Fator Quantitativo Contınuo................ 10

2.2.1. Delineamento Sistemático Tipo "Leque" ...................................... 11

2.2.2. Métodos de Análise............................................................ 14

2.3. Espaçamento para Eucalyptus dunnii............................................. 18

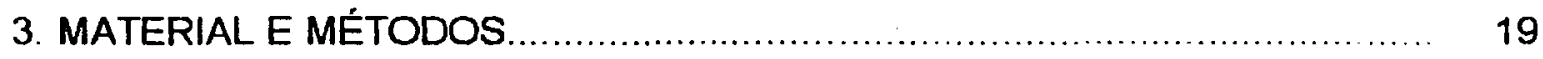

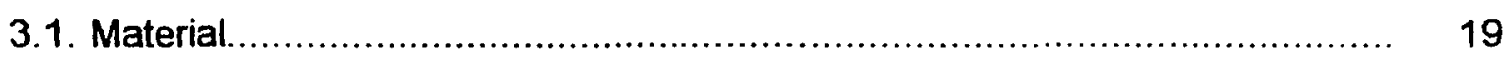

3.1.1. Localizaçăo dos Experimentos............................................. 19

3.1.2. Caracterizaçåo do Material Genético....................................... 19

3.1.3. Caracterizaçăo do Solo............................................................ 20

3.1.4. Caracterizaçăo Bioclimática.................................................. 21

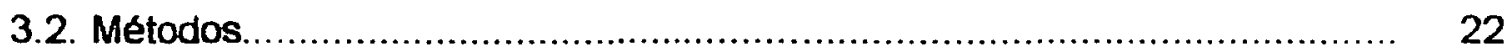

3.2.1. Delineamento em Blocos Casualizados...................................... 22

3.2.2. Delineamento Sistemático Tipo "Leque" ..................................... 25

3.2.2.1. Caracterizaçăo e Instalaçăo................................................ 25

3.2.2.2. Rearranjo das Parcelas Experimentais ............................... 28 
Página

3.2.3. Práticas Silviculturais Adotadas.

29

3.2.4. Avaliaçঠes Dendrométricas ......................................................... 30

3.2.4.1. Falhas e Bifurcaçðes.......................................................... 30

3.2.4.2. Diametro à Altura do Peito (DAP) ......................................... 32

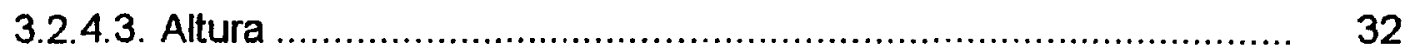

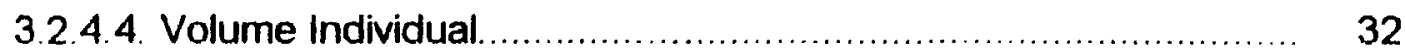

3.2.4.5. Área Basal .................................................................. 34

3.2.4.6. Volume Total ................................................................... 35

3.2.5. Análise do Delineamento em Blocos Casualizados ....................... 35

3.2.6. Análise do Delineamento Sistemático Tipo "Leque"........................ 38

3.2.7. Análise Comparativa dos Delineamentos.................................... 40

4 RESULTADOS E DISCUSSĀO ......................................... 44

4.1. Delineamento em Blocos Casualizados................................................ 44

4.1.1. Análise de Regressăo Linear............................................... 48

4.2. Delineamento Sistemático Tipo "Leque"........................................ 49

4.2.1. Análise de Regressåo Linear................................................. 59

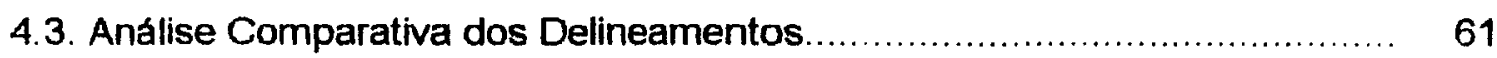

4.3.1. Regressáo Linear para Faixa Similar de Espaçamento................. 61

4.3.2. Equaçס̋es de Resposta ao Espaçamento no Delineamento Sistemático Tipo "Leque".

4.3.3. Equaçoes de Resposta ao Espaçamento Ajustadas para o Delineamento em Blocos Casualizados.

4.3.4. Exemplos llustrativos do Uso das Equações Ajustadas. 
Página

4.3.4.1. Exemplo 1

74

4.3.4.2. Exemplo 2

75

4.3.5. Aspectos Operacionais da Conduçăo dos Experimentos. 76

5. CONCLUSŌES

77

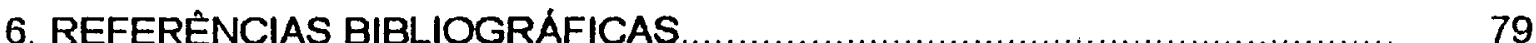

7. APÊNDICE 


\section{LISTA DE FIGURAS}

Figura

Página

1 Delineamentos sistemáticos em "sanduiche" e "xadrez" (WRIGHT, 1976)

2 Disposiçăo sistemática das parcelas experimentais dentro dos blocos, em ordem crescente de intervençăo de desbaste, comparativamente ao arranjo casualizado (DAWKINS, 1960; MEAD 1988).

3 Delineamento de espaçamento com 3 niveis de distancia entre linhas e 3 niveis de distância entre plantas (LIN \& MORSE, 1975)..

4 Delineamentos sistemáticos para estudo de espaçamento propostos por NELDER (1962), para a área horticola.

5 Repetiçסies de delineamentos sistemáticos tipo "leque" no estudo de espaçamentos (NAMKOONG, 1966).

6 Arranjo de plantio retangular para os tratamentos 1 a 4 , e em quinquóncio para o tratamento 5 , no experimento em blocos casualizados.

7 Croqui de instalaçăo do experimento em blocos casualizados e sisternático tipo "leque".

8 Valores do raio inicial ( $\left.r_{0}\right)$, raios dos tratamentos $\left(r_{1}\right.$ a $\left.r_{n}\right)$, angulo entre raios $(\theta)$ e área associada a cada planta $\left(A_{1}\right.$ a $\left.A_{n}\right)$ no delineamento sistemático tipo "leque".

9 Croqui de instalaçăo do experimento sistemático tipo "leque"

10 Ajuste da equação, das variáveis em estudo, para o delineamento em blocos casualizados $(y b)$ em funçăo do espaçamento $(x)$, e com base nas equaçǒes determinadas para o delineamento sistemático tipo "leque" (ys) e convergéncia no espaçamento de $43,95 \mathrm{~m}^{2} /$ planta.

11 DAP médio $(\mathrm{cm})$ do E.dunnii, aos 71 meses, nos diferentes espaçamentos, para o delineamento em blocos casualizados e sistemático tipo "leque".

12 Altura média $(\mathrm{m})$ do E.dunnii, aos 71 meses, nos diferentes espaçamentos, para o delineamento em blocos casualizados $\mathrm{e}$ sistemático tipo "leque". 
13 Volume individual médio (dm3/planta) do E.dunnii, aos 71 meses, nos diferentes espaçamentos, para o delineamento em blocos casualizados e sistemático tipo "leque"

14 Área basal média $\left(\mathrm{m}^{2} / \mathrm{ha}\right.$ ) do E.dunnii, aos 71 meses, nos diferentes espaçamentos, para o delineamento em blocos casualizados e sistemático tipo "leque".

15 Volume total médio $\left(\mathrm{m}^{3} / \mathrm{ha}\right.$ ) do E.dunnii, aos 71 meses, nos diferentes espaçamentos, para o delineamento em blocos casualizados e sistemático tipo "leque".

16 DAP médio $(\mathrm{cm})$, dos tratamentos 1 a 10 , para as 5 repetiçoes do delineamento sistemático tipo "leque".

17 Altura média $(\mathrm{m})$, dos tratamentos 1 a 10 , para as 5 repetiçoes do delineamento sistemático tipo "leque"....

18 Volume individual médio ( $\mathrm{dm}^{3}$ /planta), dos tratamentos 1 a 10 , para as 5 repetiçoes do delineamento sistemático tipo "leque"..

19 Área basal $\left(m^{2} / \mathrm{ha}\right)$, dos tratamentos 1 a 10 , para as 5 repetiçoes do delineamento sistemático tipo "leque".

20 Volume total ( $\mathrm{m}^{3} / \mathrm{ha}$ ), dos tratamentos 1 a 10 , para as 5 repetiçбes do delineamento sistemático tipo "leque".

21 DAP médio (cm) e regressáo linear para os experimentos em blocos casualizados e sistemático tipo "leque", na faixa similar de espaçamento.

22 Altura média $(m)$ e regressáo linear para os experimentos em blocos casualizados e sistemático tipo "leque", na faixa similar de espaçamento.

23 Volume individual médio ( $\mathrm{dm}^{3} /$ planta) e regressáo linear para os experimentos em blocos casualizados e sistemático tipo "leque", na faixa similar de espaçamento.

24 Área basal média ( $\mathrm{m}^{2} / \mathrm{ha}$ ) e regressăo linear para os experimentos em blocos casualizados e sistemático tipo "leque", na faixa similar de espaçamento

25 Volume total médio $\left(\mathrm{m}^{3} /\right.$ ha) e regressăo linear para os experimentos em blocos casualizados e sistemático tipo "leque", na faixa similar de espaçamento 
26 Intervalos de confiança dos parámetros $b_{0}$, no delineamento sistemático tipo "leque", para as 5 regressoes lineares das variáveis em estudos, relativamente aos intervalos de confiança do delineamento em blocos casualizados padronizados de 0 (limite inferior) a 100 (limite superior).....

27 Intervalos de confiança dos parâmetros $b_{1}$, no delineamento sistemático tipo "leque", para as 5 regressoes lineares das variáveis em estudos, relativamente aos intervalos de confiança do delineamento em blocos casualizados padronizados de 0 (limite inferior) a 100 (limite superior)...

28 Equaçóes de resposta do DAP em funçăo do espaçamento para o E.dunnii, aos 71 meses, no delineamento sistemático tipo "leque" e a respectiva equaçăo ajustada para blocos casualizados

29 Equaçóes de resposta da altura em funçăo do espaçamento para o E.dunnii, aos 71 meses, no delineamento sistemático tipo "leque" e a respectiva equaçăo ajustada para blocos casualizados.

30 Equaçóes de resposta do volume individual em funçăo do espaçamento para o E.dunnii, aos 71 meses, no delineamento sistemático tipo "leque" e a respectiva equaçăo ajustada para blocos casualizados.

31 Equações de resposta da área basal em função do espaçamento para o E.dunnii, aos 71 meses, no delineamento sistemático tipo "leque" e a respectiva equaçăo ajustada para blocos casualizados.

32 Equaçoes de resposta do volume total em funçăo do espaçamento para o E.dunnii, aos 71 meses, no delineamento sistemático tipo "leque" e a respectiva equaçăo ajustada para blocos casualizados.

33 Vista aérea dos experimentos de espaçamento para E.dunnii com delineamentos em blocos casualizados (à esquerda) e sistemático tipo "leque" (à direita), aos 3 meses de idade (escala aproximada 1:5000).....

34 Vista, do centro para a periferia, do experimento em delineamento sistemático tipo "leque" aos 48 meses, tendo ao fundo as parcelas do delineamento em blocos casualizados. 


\section{LISTA DE TABELAS}

Tabela

1 Análise fisica do latossolo vermelho escuro, nos diversos horizontes, antes do preparo de solo (RIZZO, 1984)

2 Análise de fertilidade do latossolo vermelho escuro, nos diversos horizontes, antes do preparo de solo (RIZZO, 1984).

3 Precipitaçoes (Ppt) e Temperaturas médias (Tem) mensais, no periodo de março de 1988 a fevereiro de 1994, no local do ensaio, em Itararé/SP

4 Tratamentos de espaçamento do E.dunnii, no experimento em blocos casualizados.

5 Plantas úteis e totais, bordaduras entre linhas e entre plantas, área útil e total das unidades amostrais do experimento em blocos casualizados....

6 Valores da distáncia radial, área por planta, densidade de plantas para 10 espaçamentos (tratamentos) no delineamento sistemático tipo "leque"

7 Número do raio das plantas excluidas da análise experimental devido a falha ou morte, sua ou de plantas vizinhas, à bifurcaçăo e árvores sorteadas para padronizar em 30 o número total de árvores por tratamento no delineamento em "leque".

8 Número do raio das plantas que compóm as 5 repetiçóes de cada tratamento no delineamento sistemático tipo "leque".

9 Coeficientes das equaçoes volumétricas ajustadas para as diferentes idades, seus coeficientes de determinaçăo $\left(R^{2}\right)$, testes $F$ e o número de árvores cubicadas.

10 Fator de expansăo para hectare ( $k$ ), para os diferentes tratamentos, nos delineamentos em blocos casualizados e sistemático tipo "leque".

11 Esquema de análise variância do delineamento em blocos casualizados.

12 Esquema de análise de variancia da regressăo linear para efeito do espaçamento no delineamento em blocos casualizados.

13 Esquema de análise de variância da regressão linear para efeito do espaçamento nos tratamentos 4,5 e 6 do delineamento sistemático tipo "leque".

14 Equaçơes de resposta ao espaçamento $(E)$ testadas para as 5 variáveis em estudo $(y)$ no delineamento sistemático tipo "leque". 
15 DAP médio $(\mathrm{cm})$, por tratamento, nas diferentes idades de avaliaçăo do E.dunnii, no delineamento em blocos casualizados.

16 Altura média $(\mathrm{m})$, por tratamento, nas diferentes idades de avaliaçăo do E.dunnii, no delineamento em blocos casualizados.

17 Volume individual ( $\mathrm{dm}^{3} /$ árvore), por tratamento, nas diferentes idades de avaliaçâo do E.dunnii, no delineamento em blocos casualizados

18 Área basal ( $\left.\mathrm{m}^{2} / \mathrm{ha}\right)$, por tratamento, nas diferentes idades de avaliaçăo do E.dunnii, no delineamento em blocos casualizados.

19 Volume total ( $\mathrm{m}^{3} / \mathrm{ha}$ ), por tratamento, nas diferentes idades de avaliaçăo do E. dunnii, no delineamento em blocos casualizados.

20 Quadrado médio do residuo (QMR), teste $F$ para tratamento, coeficiente de variaçăo experimental (CV) e eficiéncia relativa $(E R)$ do delineamento em blocos casualizados, para as 5 variáveis em estudo, nas diferentes idades

21 Valores do teste $\mathrm{F}$ para regressáo e desvio da regressăo, estimativa dos parâmetros $b_{0}$ e $b_{1}$ da regressăo linear e intervalos de confiança a $95 \%$ de probabilidade, das 5 variáveis em estudo, no delineamento em blocos casualizados, para E.dunnii, aos 71 meses.

22 DAP médio (cm), por tratamento e idade de avaliaçăo, do E.dunnii, no delineamento sistemático tipo "leque".

23 Altura média $(\mathrm{m})$, por tratamento e idade de avaliaçăo, do E.dunnii, no delineamento sistemático tipo "leque".

24 Volume individual médio ( $\mathrm{dm}^{3} / a$ rvore), por tratamento e idade de avaliaçăo, do E.dunnii, no delineamento sistemático tipo "leque".............

25 Area basal média $\left(\mathrm{m}^{2} / \mathrm{ha}\right)$, por tratamento e idade de avaliaçåo, do E. dunnii, no delineamento sistemático tipo "leque".

26 Volume total médio $\left(\mathrm{m}^{3} / \mathrm{ha}\right)$, por tratamento e idade de avaliaçăo, do E.dunnii, no delineamento sistemático tipo "leque".

$2 i$ Variância, por tratamento, para as 5 variáveis em estudo, aos 71 meses, no delineamento sistemático tipo "leque", e razâo entre a maior $(M x)$ e menor (Mi) variåncias, com e sem a participaçăo do tratamento 1 
28 Quadrado médio do residuo (QMR), teste $F$ para regressăo, estimativa dos parâmetros $b_{0}$ e $b_{1}$ da regressâo linear $e$ seus intervalos de confiança a $95 \%$ de probabilidade, das 5 variáveis em estudo, no

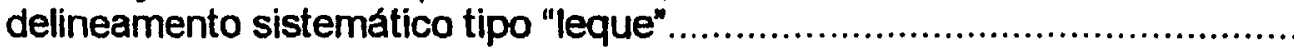

29 Valores de $F$ para regressăo, coeficiente de determinaçăo $\left(R^{2}\right)$ e soma de quadrados dos erros das variáveis originais (SQ) para as equaçōes de resposta ao espaçamento, para as 5 variáveis em estudo, no delineamento sistemático tipo "leque", para E.dunnii aos 71 meses........

30 Equaçסes de resposta ao espaçamento $E_{\text {, em }} \mathrm{m}^{2} /$ planta, selecionadas, para as 5 variáveis em estudo, no delineamento sistemático tipo "leque" (s), para o E.dunnii, aos 71 meses

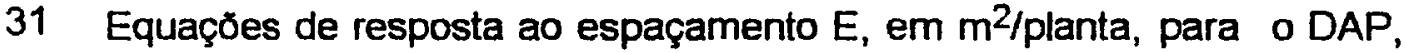
altura, volume individual, área basal e volume total, ajustadas para o delineamento em blocos casualizados (b), para E.dunnii, aos 71 meses..

32 Valores estimados para o DAP, volume individual e volume total no delineamento sistemático tipo "leque" e respectivos valores ajustados para condiçăo de blocos casualizados e relaçăo percentual entre ambos, numa faixa de 10,0 a 20,0 m²/planta, para E. dunnii, aos 71 meses. 


\title{
UTILIZAÇĀO DE DELINEAMENTO SISTEMÁTICO TIPO "LEQUE" NO ESTUDO DE ESPAÇAMENTOS FLORESTAIS
}

\author{
Autor: JOSÉ LUIZ STAPE \\ Orientador: PROF.DR. Humberto de Campos
}

\section{RESUMO}

Com objetivo de avaliar a possibilidade de utilizaçăo do delineamento sistemático tipo "leque" no estudo de espaçamentos florestais, instalaram-se, simultaneamente e em área contigua, dois experimentos com Eucalyptus dunnii, em área plana $\mathrm{e}$ homogenea, na regiáo sul do Estado de Săo Paulo. Ó primeiro experimento foi instalado no delineamento tradicional, em blocos casualizados, com 4 repetiçoes, possuindo tratamentos com espaçamentos de 3,0 $\mathrm{m} \times 1,5 \mathrm{~m}, 3,0 \mathrm{~m} \times 2,0 \mathrm{~m}, 3,0 \mathrm{~m} \times$ $2,5 \mathrm{~m}$ e $3,0 \mathrm{~m} \times 3,0 \mathrm{~m}$, os quais forneceram 4,$5 ; 6,0 ; 7,5$ e $9,0 \mathrm{~m}^{2} /$ planta. Utilizaramse parcelas úteis de 25 plantas e bordaduras duplas a quádruplas. A área total ocupada pelo experimento foi de $16764 \mathrm{~m}^{2}$, da qual $21 \%$ correspondeu à área útil. segundo experimento foi instalado em delineamento sistemático tipo "leque", formando círculo completo, com 36 raios e 12 plantas por raio, sendo a primeira e ultima planta de cada raio consideradas como bordaduras. As áreas por planta testadas, referentes às 10 plantas internas dos raios, foram: 1,$40 ; 2,05 ; 3,01 ; 4,41$; 6,$47 ; 9,50 ; 13,93 ; 20,43 ; 29,97$ e 43,95 $\mathrm{m}^{2} /$ planta, e após eliminaçăo dos efeitos de falhas e bifurcaçסes, estabeleceram-se 5 repetiçoes de 6 plantas por parcela. Este experimento ocupou uma área de $5972 \mathrm{~m}^{2}$, da qual 82\% correspondeu à área útil. Qs experimentos foram avaliados aos $26,42,48,60$ e 71 meses de idade, calculando-se, por parcela, o diametro médio à altura do peito, a altura média, o volume individual médio, a área basal e o volume total por hectare. Dada a grande quantidade de informaçס̄es obtidas e pela possibilidade de múltiplos enfoques na análise dos dados, o presente trabalho se propoe a ser uma primeira abordagem dos resultados, 
possibilitando novas interpretaçס̃es e análises. As análises de variáncia efetuadas no delineamento em blocos casualizados, evidenciaram a homogeneidade local, com baixos coeficientes de variaçăo experimental e eficiencias relativas iguais ou inferiores ao delineamento inteiramente ao acaso. Para o estudo de resposta das variáveis dendrométricas ao espaçamento, trabalhou-se com os dados relativos à idade de 71 meses, idade média de exploraçăo da espécie. Procedeu-se às análises de regressăo linear tendo em cada caso, como variável dependente, uma das 5 variáveis em estudo e como variável independente o espaçamento por planta, numa faixa similar de espaçamentos, para ambos experimentos. Estas análises evidenciaram comportamento semelhante das variáveis, frente ao espaçamento, nos dois delineamentos, expresso através da sobreposiçăo dos intervalos de confiança dos coeficientes lineares e angulares das regressóes. Observou-se, porém, uma tendéncia de superioridade dos coeficientes lineares dessas regressóes, no delineamento sistemático tipo "leque" comparativamente aos blocos casualizados, assim como uma maior variancia residual neste delineamento. Evidenciou-se, assim, que o delineamento sistemático, isoladamente, pode náo ser indicado para a inferencia de dados para a condiçăo de maciço florestal. Como forma de contornar esta tendencia de diferenciaçăo de comportamento das variáveis dendrométricas nos delineamentos, para espaçamentos semelhantes, e possibilitar a utilizaçăo segura dos resultados obtidos em delineamento sistemático tipo "leque" na recomendaçăo de espaçamentos para plantios comerciais, utilizou-se de uma metodologia de ajuste dos resultados obtidos neste delineamento para as condiçoes do delineamento em blocos casualizados. Para isso, estabeleceram-se regressరes baseadas no delineamento sistemático tipo "leque", e através dos valores obtidos no delineamento em blocos casualizados, tomados como "referéncia" de um plantio comercial, e da suposiçăo de convergéncia de comportamento para ambos delineamentos em espaçamento amplo, obtiveram-se equaçoes finais que estimam as variáveis em estudo para as condiçoes de maciço florestal. Conclui-se, portanto, que os delineamentos sistemáticos tipo "leque", na área florestal, podem ser utilizados de forma mais eficiente do que simplesmente servindo como experimentos exploratorios, desde que os tratamentos e parcelas "referencias" sejam cuidadosamente considerados no planejamento experimental. 


\title{
THE USAGE OF A "FAN" SYSTEMATIC DESIGN FOR FOREST SPACING STUDIES
}

\author{
Author: JOSÉ LUIZ STAPE \\ Adviser: PROF.DR. Humberto de Campos
}

\section{SUMMARY}

In order to evaluate the possibility of usage the "fan" systematic design for forest spacing studies, two experiments were installed simultaneously and closely with Eucalyptus dunnii, on a flat and homogeneous area, in the Southern of Saco Paulo State. The first experiment was planted on a traditional design, randomized blocks, with 4 repetitions, with the following spacings $3,0 \mathrm{~m} \times 1,5 \mathrm{~m}, 3,0 \mathrm{~m} \times 2,0 \mathrm{~m}, 3,0 \mathrm{~m} \times$ $2,5 \mathrm{~m}$ and $3,0 \mathrm{~m} \times 3,0 \mathrm{~m}$, which gave 4,$5 ; 6,0 ; 7,5$ and $9,0 \mathrm{~m}^{2} / \mathrm{plant}$. Each experimental plot had 25 measured plants and guard plants. The experiment required $16764 \mathrm{~m}^{2}$ and $21 \%$ of this area was useful. The second experiment was installed on a "fan" systematic design, shaping a circle, with 36 radii and 12 plants per each, considering the first and the last plant of each radii as guards. The spacings tested were: 1,$40 ; 2,05 ; 3,01 ; 4,41 ; 6,47 ; 9,50 ; 13,93 ; 20,43 ; 29,97$ and $43,95 \mathrm{~m}^{2}$ /plant, and after failure, mortality and forking effects elimination, 5 repetitions, of 6 plants per plot, were established. This experiment required $5972 \mathrm{~m}^{2}$ and $82 \%$ was useful area. Both experiments were measured at $26,42,48,60$ and 71 months old, computing, per plot, the average $\mathrm{DBH}$, height, individual volume, basal area and total volume per hectare The analysis of variance done for the randomized block design, showed the site homogeneity, with low experimental coefficients of variation and with relative efficiencies equal or less than one. The response of the dendrometric variables according to the spacing, was studied with the data corresponding to 71 months old, the average harvesting age of the specie. The linear regression analysis was done 
taking the 5 dendrometric variables as dependent variable, and the spacing as the independent one, on a similar band of spacings, for both designs. These analyses showed analogous behavior of the variables in function of spacing, on both designs, explicited by the overlay of the confidence intervals of the linear and angular regression coefficients. It was observed a trend of superiority of the linear coefficients on the "fan" design compared with the randomized blocks design, and a higher residual variance. It may show that the "fan" design could not be adequate to infer data for commercial forest. As a way to solve this trend of different behaviors of dendrometric variables for a equal spacing depending on the designs, and to permit the safe usage of the results obtained on the "fan" design for commercial purpose, a methodology to adjust the results for the randomized blocks was used. For this, regressions based on the "fan" design were established and through the values obtained on the randomized blocks, taken as "guides" of a commercial plantation, and the assumption of a convergence of the behavior of the designs for wide spancings, final equations were established, capable of estimating the dendrometric variables for commercial planting. It was concluded that the "fan" design may be used, on forestry studies, more efficiently than only as exploratory experiments, since the treatments and the "guide" plots be carefully considered during the experimental planning. 


\section{INTRODUÇÃo}

O plantio de povoamentos florestais puros e equiâneos desempenha, a nivel nacional, um importantissimo papel sócio-ecoñómico ao gerar uma gama de produtos florestais como celulose, papel, chapas, carvâo, madeira para energia, serraria, construçóes, postes, dormentes, além de óleos essenciais e resinas.

Estes maciços somam cerca de 7 milhoes de hectares (IBDF, 1988), em todo o pals, dos quais $52 \%$ sâo representados pelo género Eucalyptus.

O sucesso de qualquer empreendimento florestal passa, necessariamente, por um adequado planejamento da implantaçăo de suas florestas, no que diz respeito à escolha da espécie, procedencia ou clone, do preparo e conservaçăo do solo, da fertilizaçăo, do plantio e do manejo florestal.

Um dos principais aspectos envolvidos neste manejo se refere à correta densidade de árvores por unidade de área, no plantio e ao longo do cicio da floresta, pois ela influenciará năo só o crescimento individual das plantas como também o seu crescimento conjunto.

Assim, a densidade é uma variável que deve ser manejada em funçăo de uma série de fatores relativos ao comportamento das plantas em maciços, às condiçoes edafo-climáticas do local e ao produto final almejado.

Esta densidade, determinada pelo espaçamento entre árvores, ou pela área associada a cada planta, é portanto uma variável de interesse, sendo continuadamente estudada a nivel experimental em funçăo da constante introduçăo de novas espécies, procedencias e clones em plantios já estabelecidos, bem como devido a implantaçăo de novos projetos florestais em zonas ecológicas distintas.

Os experimentos de espaçamento florestal se caracterizam pelas grandes áreas necessárias para suas instalaçôes, comparativamente aos experimentos agricolas, isto porque a área por planta se situa entre 4 e $20 \mathrm{~m}^{2}$, sendo, em geral, 
necessárias parcelas experimentais de 400 a $800 \mathrm{~m}^{2}$ (EVERT, 1971), para que possam conter um número suficiente de individuos mensuráveis.

Outro fator que inflaciona a área necessária à experimentaçăo é a necessidade de bordadura entre os tratamentos, face a influéncia exercida pelas árvores de uma parcela sobre as árvores das parcelas vizinhas, em funçăo das grandes dimensóes das copas e sistemas radiculares das plantas.

Desta forma, a instalaçăo de experimentos tradicionais com repetiçóes, aleatorizaçáo dos tratamentos, controle local e bordadura, tem restringido o número de espaçamentos ensaiados, dadas as dificuldades relativas as disponibilidades de área e recursos para instalaçăo, manutençōes e avaliaçōes.

Além disso, mesmo em se querendo testar um grande número de espaçamentos, a área experimental total requerida seria tăo vultosa que certamente năo conseguiria garantir a homogeneidade dentro dos blocos, inflacionando o erro experimental, e consequentemente diminuindo a sensibilidade na comparaçăo dos efeitos dos tratamentos.

Esta restriçăo no número de espaçamentos estudados por experimento acarreta um menor conhecimento e compreensăo do comportamento dos maciças florestais frente a diferentes densidades populacionais, ocasionando, muitas vezes, a conduçăo de florestas de forma pouco eficiente para atingir seus objetivos finais, em termos de produçăo e sortimento.

Visando superar, em parte, tais restriçóes, estudiosos do setor florestal propuseram no inicio da década de 60, delineamentos em que as bordaduras seriam eliminadas, ou diminuidas, ao se disporem os tratamentos numa ordem sistemática com gradientes crescentes da variável quantitativa em estudo, no caso densidade de plantas, funcionando cada tratamento como bordadura entre o tratamento anterior e o posterior.

Estes delineamentos, ditos sistemáticos, pressupunham que houvesse uma forte justificativa para seu emprego, preconizando a utilizaçăo de áreas sabidamente homogéneas e permitindo que as mesmas tivessem menores dimensoes e pudessem testar um maior número de tratamentos.

Concomitante a essa tentativa de aumentar o número de espaçamentos testados nos ensaios florestais, surgiram, na área hortlcola, delineamentos 
sistemáticos para estudo de espaçamentos, baseados em desenhos geométricos circulares e retangulares, sob o apelo de que as bordaduras seriam dispensáveis pela intercompensaçăo anteriormente citada, e que a falta de aleatorizaçăo dos tratamentos náo seria tâo prejudicial, uma vez que as áreas de instalaçăo, pequenos canteiros horticolas, 'seriam garantidamente homogêneas.

Dentre estes delineamentos, propostos por NELDER (1962), o delineamento sistemático tipo "leque" tem sido o mais utilizado em experimentaçăo de campo, inicialmente em horticultura, sendo posteriormente introduzido na área agrícola para culturas puras e consorciaçăo, e na área florestal nos estudos sobre plantios homogéneos e agrossilvicultura.

A rápida utilizaçăo deste delineamento na área florestal deve ser creditada à sua compacidade, necessitando de pequena área experimental e sendo de fácil manejo, e abrangência, possibilitando o estudo de um grande número de espaçamentos.

No entanto, por ferir o principio básico da casualizaçáo, na alocaçáo dos tratamentos, o delineamento em "leque" năo garante a independéncia dos erros associados a cada unidade experimental, impossibilitando a sua análise estatística de forma tradicional. Esta falta de aleatorizaçăo vem sendo, sem dúvida alguma, a principal preocupaçăo na recomendaçăo ou năo deste delineamento no estudo de espaçamentos, por impossibilitar uma correta estimativa e comparaçăo entre os efeitos de tratamentos, devido à impossibilidade de se estimar o erro experimental.

Afora este aspecto, vale ressaltar que as parcelas experimentais do delineamento em "leque" nâo representam a disposiçăo das árvores nos plantios comerciais, e possuem diferentes fatores de expansăo, sendo outro entrave na extrapolaçăo dos resultados experimentais desse delineamento para recomendaçōes práticas de espaçamentos de plantio.

O uso de modelos de regressáo nos delineamentos sistemáticos sempre foi sugerido e utilizado, tendo como variável dependente alguma medida de crescimento ou produçấo, e como variável independente a densidade de plantas.

No entanto, estas regressoes, embora üteis na comparaçăo relativa entre tratamentos dentro do próprio ensaio, nåo possibilitam a determinaçăo do desvio das 
estimativas de produção por área obtidas no delineamento em "leque" e aquelas que seriam auferidas em plantios comerciais sob aquela densidade.

Esta dificuldade tem sido contornada elegendo-se tratamentos promissores no delineamento sistemático e repetindo-os, agora num delineamento tradicional casualizado, para definiçăo correta dos espaçamentos e suas estimativas.

A adoçăo desta recomendaçăo na área florestal certamente implicaria em atraso substancial na obtençăo de tâo importante definiçăo, uma vez que se tomaria de 6 a 11 anos para concluir o experimento com delineamento tipo "leque" e mais 6 a 11 anos para concluir o experimento com delineamento casualizado, totalizando 12 a 22 anos para a definiçăo do espaçamento ideal de plantio. Desta forma, esta informaçăo já teria uma baixa utilidade, em funçăo de terem-se, certamente, sido selecionados ou introduzidos materiais genéticos mais produtivos e que necessitariam novamente de estudos de espaçamento.

Assim, se por um lado os delineamentos tipo "leque" possuem atrativos ao experimentador florestal em funçăo das grandes vantagens de compacidade, abrangéncia e fácil manejo, por outro lado penalizam-no com insegurança de análise, interpretaçáo e extrapolaçấo dos resultados obtidos.

Objetivando esclarecer, em parte, a possibilidade de utilizaçăo de delineamentos tipo "leque" no estudo de espaçamentos florestais comparativamente aos delineamentos em blocos casualizados tradicionais, instalaram-se um experimento com delineamento sistemático tipo "leque" e outro com delineamento em blocos casualizados com Eucalyptus dunnii, em áreas contiguas e homogéneas, possuindo faixas de densidades que se sobrepunham, fazendo-se mensuraçoes dendrométricas até a idade de 6 anos. 


\section{REVISÃO DE LITERATURA}

\subsection{Delineamentos Experimentals no Estudo de Espaçamentos Florestais}

- estudo sobre espaçamento sempre mereceu destaque na experimentaçăo florestal por estar diretamente relacionado a uma série de fatores de extrema importáncia para o manejo e retorno económico das florestas (SMITH, 1958; ASSMANN, 1970).

EVERT (1971) e BALLONI \& SIMŌES (1980) ilustram que o espaçamento influencia diretamente a taxa de crescimento das árvores, a taxa de crescimento do povoamento, a qualidade e sortimento da madeira, os tratos culturais, os custos de implantaçăo, manutençăo, proteçăo e exploraçăo, a conservaçăo do solo e a rentabilidade da floresta, dentre outros fatores.

WRIGHT (1976) relata que os delineamentos experimentais para estudos de espaçamento e modelos de crescimento florestal se caracterizaram, até o inicio deste século, pela utilizaçăo de parcelas sem repetiçăo, sendo que os primeiros delineamentos a introduzirem repetiçoes o faziam de forma sistemática, em "sandulche" ou "xadrez" conforme mostra a Figura 1.

"Sandulche"

\begin{tabular}{|l|l|l|l|}
\hline$A$ & $B$ & $B$ & $A$ \\
\hline$B$ & $A$ & $A$ & $B$ \\
\hline
\end{tabular}

"Xadrez"

\begin{tabular}{|c|c|c|c|}
\hline$A$ & $B$ & $C$ & $D$ \\
\hline$B$ & $C$ & $D$ & $A$ \\
\hline$C$ & $D$ & $A$ & $B$ \\
\hline$D$ & $A$ & $B$ & $C$ \\
\hline
\end{tabular}

FIGURA 1. Delineamentos sistemáticos em "sanduiche" e "xadrez" (WRIGHT, 1976). 
Com a introduçăo dos novos conceitos em estatística e experimentaçăo nas décadas de 20 e 30 , houve uma reformulaçăo das bases teóricas envolvidas no planejamento experimental, sendo, segundo COCHRAM \& COX (1978), a aleatorizaçăo o conceito moderno introduzido por Fisher.

Após esta introduçăo, os experimentos de espaçamentos em florestas passaram paulatinamente a utilizar os delineamentos com aleatorizaçáo, notadamente os blocos casualizados e os quadrados latinos (WRIGHT, 1976). EVERT (1971) acrescenta que com o desenvolvimento das ferramentas de regressăo, os tratamentos nos blocos casualizados passaram a ser niveis equidistantes de espaçamento.

A área das parcelas experimentais para estudo de espaçamentos florestais varia de 400 a $800 \mathrm{~m}^{2}$ (EVERT, 1971; WALTERS, 1980), objetivando garantir um número adequado de árvores úteis mensuráveis até o final do ciclo florestal. GOMES \& COUTO (1985) ao estudarem experimentos de fertilizaçăo e melhoramento de Eucalyptus, chegam a tamanhos minimos de parcelas de 16 plantas totais, com 4 plantas úteis, e que mesmo assim, para estudos de espaçamentos já situariam a área de cada parcela experimental entre 100 e $300 \mathrm{~m}^{2}$

Assim, dada a necessidade de áreas maiores para experimentos florestais, o número de repetiçóes passou a ser restritivo, além da dificuldade de se terem áreas realmente homogéneas (LIN \& MORSE, 1975).

Como forma alternativa de diminuir a área experimental, Pudden, citado por DAWKINS (1960), propóe uma estratégia de delineamento sistemático, em experimentos de desbastes florestais, com gradientes crescentes de intensidades de intervenção numa direção, eliminando as bordaduras, e aleatorizando esta direção dentro dos blocos, como mostra a Figura 2.

Porém, SCOTT (1962) critica duramente esta estratégia, se prendendo em defender a aleatorizaçăo dos tratamentos, năo valorizando as razóes de ordem lógicas e práticas levantadas por DAWKINS (1960), e lembrando que a falta da aleatorização impossibilita a análise de variância por quebrar a independéncia dos resíduos e que a análise de regressão ficaria condicionada à inciusão de uma variável para caracterização do sítio, entre repetições. 


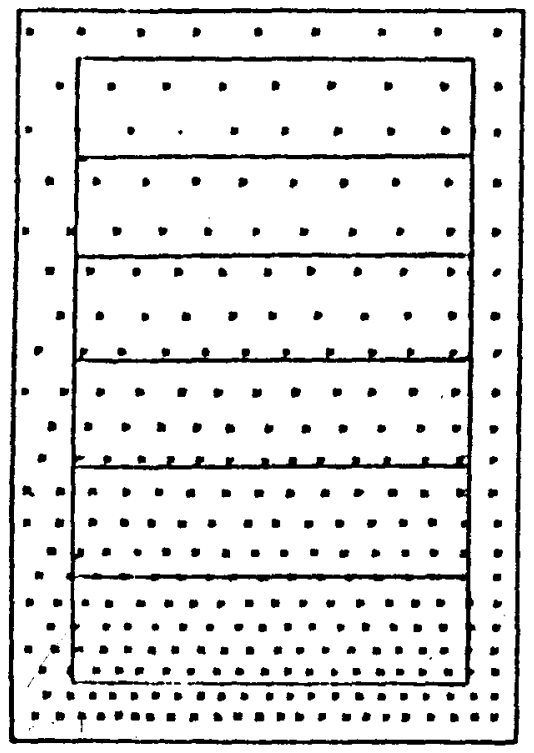

Sistemático

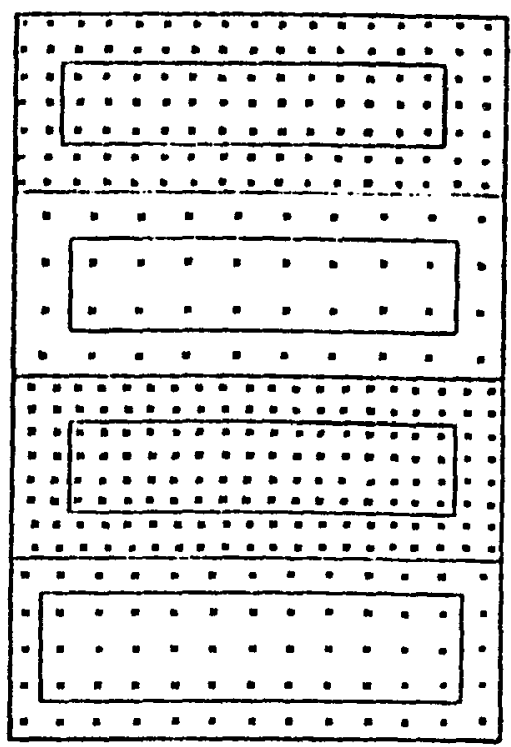

Casualizado

FIGURA 2. Disposiçăo sistemática das parcelas experimentais dentro dos blocos, em ordem crescente de intervençăo de desbaste, comparativamente ao arranjo casualizado (DAWKINS, 1960; MEAD, 1988).

COX (1958) classifica a determinaçăo do arranjo dos tratamentos, dentro de um determinado bloco, em trés métodos distintos: aleatório, sistemático e subjetivo. No aleatório, a cada tratamento é associada uma parcela experimental, aleatoriamente, e sem reposiçăo. No sistemático, a ordern dos tratamentos está sequencialmente definida em funçăo de se ter um bom conhecimento das variaçóes nâo controladas e de haver uma forte justificativa para este arranjo. No subjetivo, o experimentador associa, por critérios pessoais, os tratamentos às unidades experimentais. Finalmente, o autor condena o arranjo subjetivo, que, diferentemente dos anteriores, possibilita a existéncia de tendenciosidade do experimentador, náo existindo argumento de simplificaçăo que o justifique.

FISHER (1935) aponta a dificuldade em se estimar o erro experimental como uma forte objeçăo aos delineamentos sistemáticos, além do arranjo dos tratamentos poder coincidir com algum padrăo de variaçăo nấo controlada, viciando as estimativas dos efeitos dos tratamentos e a estimativa da variância das estimativas desses efeitos. 
Objetivando evitar a utilizaçăo desordenada de experimentos sistemáticos, como os propostos por DAWKINS (1960), realizou-se, em jurho de 1961, uma conferencia em Oxford para discussăo do tema, reforçando-se a objeçáo a esse tipo de delineamento, pela impossibilidade de sua análise e consequentemente sua utilizaçáo prática (SCOTT, 1962).

Sobre esta discussáo entre aleatorizaçáo e sistematização é importante ressaltar a observaçăo feita por YATES (1938) de que năo se discute mais o fim da aleatorizaçăo, mas sim a avaliaçăo de sua real necessidade em certos casos.

FREEMAN (1988), numa revisão sobre os delineamentos sistemáticos identifica diferentes grupos de delineamentos sob esta mesma denominaçắo Distingue então dois tipos básicos de delineamentos sistemáticos: o primeiro em que a sistematizaçăo é necessária em funçăo de uma particularidade inerente ao material amostral disponivel, como experimentos em indústrias e na área médica; e o segundo grupo em que a sistematizaçăo é devida a existéncia de niveis quantitativos contínuos nos tratamentos, os quais săo dispostos numa ordem crescente ou decrescente, nas unidades experimentais, objetivando reduzir ou eliminar as bordaduras, diminuir a área experimental e aumentar o número de tratamentos em teste.

O uso da sistematização, quando năo há fator quantitativo em estudo, năo se justifica e não traz ganho algum à experimentaçăo, como bem demostra CHALITA (1991) num estudo sobre delineamento sistemático para testar variedades de cafeeiros. O autor conclui que tal arranjo mostrou-se inadequado, tornando complexa a análise e necessitando de ajustes de gradientes de fertilidade. Estes ajustes de gradientes, em termos de sua deteç̧ăo e remoçăo săo também discutidos por COX (1951).

COX (1958) alerta que a instalaçăo de experimentos sistemáticos numa área considerada "homogénea" é baseada apenas na opiniåo do pesquisador, e que quando um resultado surpreendente ocorre, o pesquisador imediatamente questiona a validade do arranjo sistemático. O autor ainda comenta que a eliminaçáo do "bias" na estimativa do erro pode, provavelmente, ser removida por uma modificaçáo do método de análise, mas que os diferentes métodos náo deixam claro qual deva ser utilizada. Finalmente, pondera que os delineamentos sistemáticos devern ser 
tolerados dentro de limites bem definidos de conhecimento do pesquisador e de sua praticidade.

LIN \& MORSE (1975) sugerem delineamentos mais compactos para estudo de espaçamentos através da divisáo do espaçamento em dois fatores, as distâncias entre linhas e entre plantas, como mostra a Figura 3, e que possibilitam a análise de variancia tradicional. Os autores náo recomendam os delineamentos sistemáticos pelo fato de poder haver um gradiente ambiental na área que viciará as estimativas dos efeitos dos tratamentos e também por que os residuos estariam correlacionados de forma desconhecida. Alertam, ainda, para a possibilidade de heterocedasticidade devido à competiçăo diferenciada entre as parcelas.

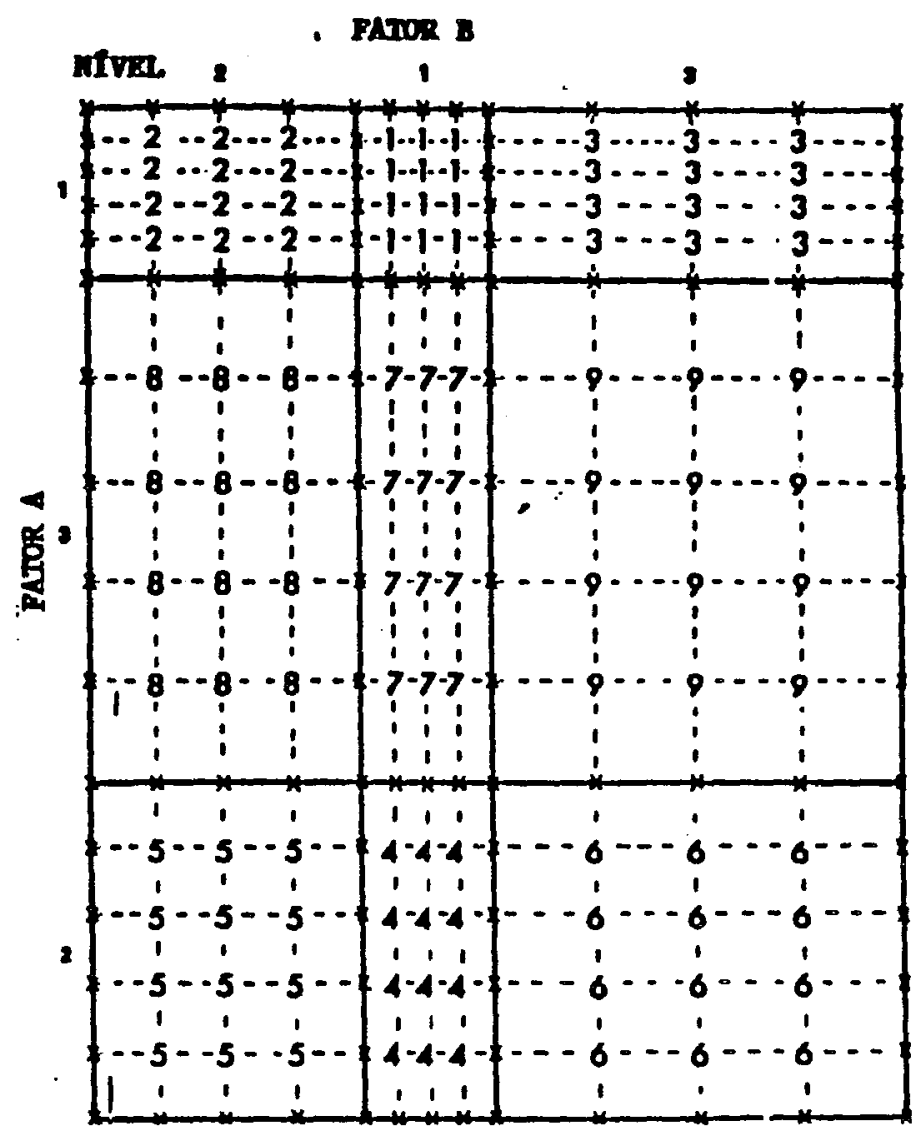

FIGURA 3. Delineamento de espaçamento com 3 niveis de distáncia entre linhas e 3 niveis de distáncia entre plantas (LIN \& MORSE, 1975).

Apesar destas preocupações relativas à estimativa do erro experimental e, consequentemente, a análise estatistica deste experimentos, as grandes vantagens práticas na instalaçåo dos delineamentos sistemáticos com fator quantitativo 
contínuo, aliadas ao forte apelo intuitivo de sua concepçáo mais compacta e abrangente, levou também a área florestal, espelhando-se nas áreas horticola e agricola, a utilizar-se dos mesmos em seus estudos de espaçamentos (WRIGHT, 1976).

\subsection{Delineamentos Sistemáticos com Fator Quantitativo Continuo}

Os delineamentos sistemáticos com fator quantitativo contínuo săo aqueles em que os tratamentos representam doses ou valores crescentes de um determinado fator e que sáo arranjados nas unidades experimentais em ordem crescente ou decrescente (FREEMAN, 1988).

Estes delineamentos foram inicialmente propostos para a área horticola por NELDER (1962), Figura 4, baseando-se na homogeneidade da área experimental e na baixa correlaçăo entre parcelas vizinhas. Além disso, o autor sugere que os delineamentos sistemáticos, para estudo de espaçamentos, quando compactos e colocados em gradientes crescentes, poderiam dispensar as plantas de bordadura, pois os efeitos das parcelas anterior e posterior em relaçåo a uma determinada parcela, seriam compensatórios.
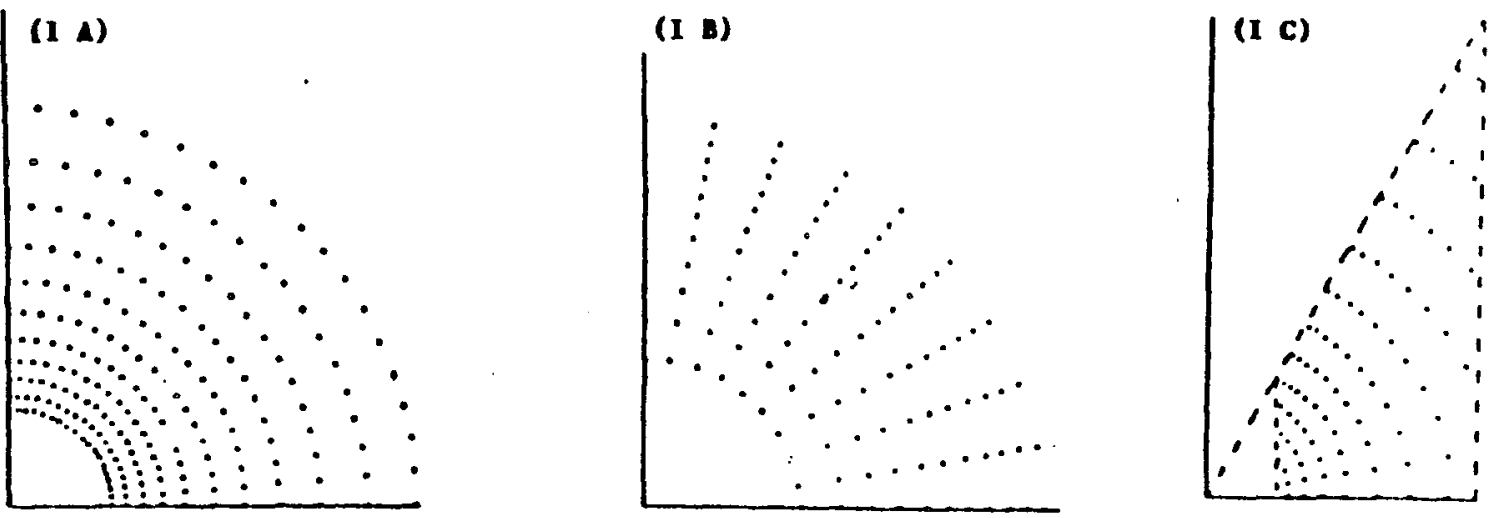

FIGURA 4. Delineamentos sistemáticos para estudo de espaçamento propostos por NELDER (1962), para a área horticola.

O autor aponta as seguintes vantagens ao comparar os delineamentos sistemáticos com os aleatórios: delineamento mais compacto, redução de heterogeneidade local e inexistência de bordadura. Entre as desvantagens relaciona o 
risco de gradientes sistemáticos causando "bias" nas estimativas dos efeitos e no erro, e no risco de interaçăo entre parcelas vizinhas.

HUXLEY (1985) arrola as seguintes premissas para a instalaçăo de um delineamento sistemático: área uniforme, plana e com tratos culturais adequadamente realizados. Considera-o como tendo caráter exploratório e devendo ser seguido de experimentos robustos para uma faixa de tratamentos identificada como potencial, para análises precisas de crescimento. PEARCE (1989) e RAO et alii (1990) também ratificam este uso dos delineamentos sistemáticos.

\subsubsection{Delineamento Sistemático Tipo "Leque"}

Dentre os cinco delineamentos sistemáticos com fator quantitativo cont/nuo propostos por NELDER (1962), destaca-se o denominado delineamento sistemático tipo "leque" (IA), que se caracteriza por ser baseado num sistema de raios e arcos de circulos concêntricos, onde a retangularidade, ou seja, a razăo entre as distáncias inter e intra linhas, é constante. Neste delineamento, esquematizado na Figura 4, a área por planta aumenta com o aumento da distância à origem, sendo os raios separados por um ângulo constante e os arcos espaçados por uma progressão geométrica da distância radial. O cálculo desses valores de geometria plana e suas relaçóes săo detalhados pelo autor, e reforçados ou ampliados na sua utilizaçăo por BLEASDALE (1966), NAMKOONG (1966), FREYMAN \& DOLMAN (1971), ROGERS (1972) e CHALITA (1991).

Os 3 principais valores que definem este delineamento săo $r_{0}$ (primeira distáncia radial), $\alpha$ (fator da progressâo geométrica radial) e $\theta$ (ângulo entre raios). Além destes, destacam-se a retangularidade $\tau$, e a área associada por planta $A_{n}$ As relações existentes entre estes valores são:

$$
r_{n+1}=r_{n} \alpha \quad \tau=\theta /\left(\alpha^{1 / 2}-\alpha^{-1 / 2}\right) \quad A_{n}=\theta \quad r_{n}^{2}\left(\alpha-\alpha^{-1}\right) / 2
$$

MEAD (1988) lembra que a concepçăo básica para eliminaçăo das bordaduras baseia-se no efeito compensatório, e que para isso os incrementos no 
fator quantitativo devem ser de no máximo $10 \%$, valor este referido por NELDER (1962) como um $\alpha$ máximo de 1,111.

NELDER (1962) enfatiza a preocupaçăo com a retangularidade identificando-a como um fator distinto de análise no caso de plantas horticolas. ROGERS (1972) detalha a definiçăo de retangularidade nos delineamentos tipo "leque", uma vez que as distâncias entre plantas, nos arcos, podem ser tomadas sobre o arco, ou sobre a corda que imaginariamente unem as plantas vizinhas.

Estudando o crescimento de berinjela em um delineamento tipo "leque" e em um delineamento tradicional, MINAMI (1977) registra maior facilidade de manejo e produçăo por área no delineamento sistemático, creditando-a a um manejo mais acurado, e aponta como sua única desvantagem a impossibilidade de análise estatistica. Salienta que os dois experimentos forneceram a mesma tendéncia de acréscimo da produçăo por planta e decréscimo da produçăo por área com o aumento do espaçamento. FINCH et alii (1976) utilizaram o delineamento sistemático tipo "leque" para avaliar infestaçáo de insetos em ralzes de brássicas obtendo uma relação decrescente entre infestaçăo e espaçamento.

Da sua concepçăo para área hortícola os delineamentos tipo "leque" foram rapidamente aplicados em plantas arbóreas por FREEMAN (1964) no estudo de espaçamento em cacau, onde numa pequena área irregular, pode-se instalar 3 repetições do delineamento. Seguiram-se a instalaçăo de delineamentos tipo "leque" na área florestal por Van Slyke (1966) e Chacko (1966), citados por EVERT (1971), MYERS et alii (1970), TENNENT (1975), WRIGHT (1976) e LAND \& NANCE (1987).

Estas constantes pesquisas de espaçamento estăo ligadas à necessidade de definiçăo da melhor combinaçăo entre genótipo e espaçamento, para os novos sítios que văo sendo utilizados em reflorestamento (CANNON, 1981; BALLONI \& SIMÓES 1980), e para as novas introduçǒes de materiais genéticos (NAMKOONG, 1966; LAND \& NANCE, 1987).

NAMKOONG (1966) considera o delineamento tipo "leque" de extrema utilidade em estudo da resposta de diferentes genótipos de árvores ao espaçamento. por permitir se trabalhar com um grande número de familias em diferentes espaçamentos e numa área compacta. A retangularidade năo é vista pelo autor como preocupante em função do longo ciclo de crescimento permitir ajustes 
compensatórios. Recomenda ainda, que estes delineamentos sejam seriamente considerados em melhoramento florestal e silvicultura e que se façam repetiçóes dos "leques", como ilustra a Figura 5.

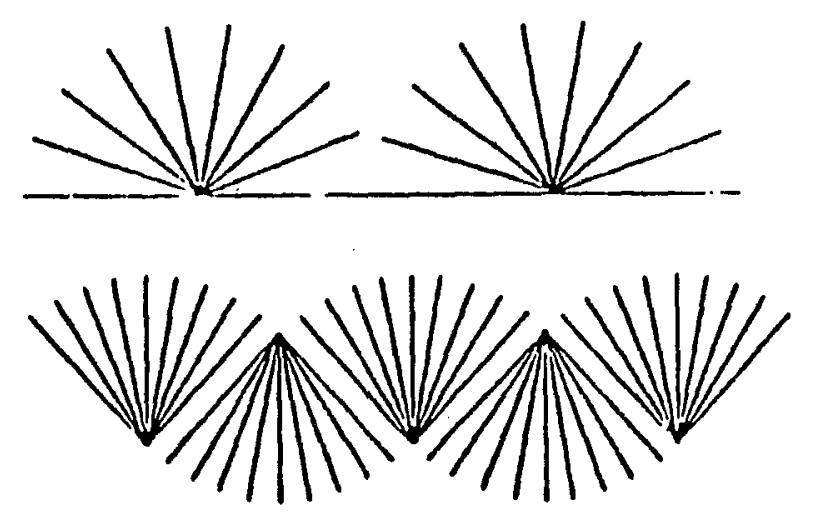

FIGURA 5. Repetiçoes de delineamentos sistemáticos tipo "leque" no estudo de espaçamentos (NAMKOONG, 1966).

Seguindo esta recomendaçăo, LAND \& NANCE (1987) utilizaram um delineamento tipo "leque" para testar progênies de Pinus taeda, sendo que cada familia foi representada por 5 raios contíguos, com 5 densidades de plantio, entre 1077 e 2990 árvores/ha. Os autores demostram, para a idade de 10 anos, a interaçáo entre progénies e espaçamento, sugerindo uma forma de determinar a área potencialmente disponivel por planta para corrigir os desvios causados por mortalidade e domináncia de árvores, utilizando-a como covariável na análise.

MURTRIE \& WOLF (1983) utilizaram um delineamento tipo "leque" para estabelecer um modelo de competiçăo entre árvores e gramíneas por luz, água e nutrientes. HUXLEY (1985) lembra que as bordaduras externas no caso dos delineamentos tipo "leque" devem ser observadas para evitar distorçăo das curvas de crescimento nos tratamentos extremos, e que os "leques" devem ser repicados e casualizados quanto à sua orientaçăo, e se forem só 2, devem ser perpendiculares entre si. PEARCE (1989) também diagnostica que o delineamento tipo "leque" seguramente irá criar gradientes microclimáticos internos ao experimento, como por exemplo em relaçăo à direçăo predominante do vento, recomendando dispor as repetiçóes de forma ortogonal. 


\subsubsection{Métodos de Análise}

A despeito do grande número de experimentos sistemáticos sugeridos por diversos autores, EVERT (1971) e LIN \& MORSE (1975) comentam que quase inexistem trabalhos efetuando análises estatisticas de delineamentos sistemáticos, o que seria de grande utilidade para realmente se por à prova seus aspectos positivos e negativos.

Chacko (1966), citado por EVERT (1971), relata que experimentos florestais em blocos compactos indicaram que a maior fonte de variaçăo experimental recaia sobre o material genético e menos sobre a fertilidade do solo, o que poderia sugerir a simplificaçăo da análise de variância, efetuando-a como se o delineamento fosse aleatório. Jenkyn et alii (1979), citado por FREEMAN (1988), também utilizam a análise de variáncia convencional tratando seus experimentos como aleatórios, mas introduziram a análise de covariância para alertar sobre interaçóes entre parcelas vizinhas. Quanto a esta prática PEARCE (1989) critica-a comentando que năo se pode tomar como aleatórios valores que sabidamente năo o săo.

DAWKINS (1960), SCOTT(1962), NELDER (1962), NAMKOONG (1967), EVERT (1971), WRIGHT (1976), HUXLEY \& MAINGU (1978), HUXLEY (1985), MEAD (1988) e PEARCE (1989) recomendam a análise de regressão como uma das grandes ferramentas de análise de delineamentos sistemáticos com niveis crescentes do fator nos tratamentos. HUXLEY (1985) ainda sugere que devido a possibilidade de dominância entre parcelas vizinhas, se utilize médias móveis.

MEAD (1988) comenta que apesar de ser a variabilidade entre plantas a principal componente da variancia residual, comparativamente a variabilidade do solo ou algum gradiente de fertilidade local desconhecida, as dúvidas sobre estes argumentos năo satisfarâo uma análise de variância tradicional.

HOLLIDAY (1960) caracteriza a relaçăo entre produçăo por planta e por área em funçáo da densidade de plantas e NELDER (1962) sugere a seguinte relaçăo entre produçåo por planta $(\omega)$ e densidade $(\rho)$, tendo-se os parametros $\alpha, \beta$ e $\theta$ :

$$
\omega^{-\theta}=\alpha+\beta \cdot \rho
$$


Segundo 0 autor, $\beta$ seria dependente da retangularidade. BERRY (1967) desdobra esta equaçào, utilizando valores de espaçamento entre linhas e entre plantas para caracterizar a retangularidade.

NAMKOONG (1967) sugere a equaçáo de RICHARDS (1959) no ajuste de modelos de crescimento para espaçamentos florestais por considerá-la bastante flexivel no ajuste de qualquer forma de crescimento vegetativo, mostrando que a equaçăo sugerida por NELDER (1962) é apenas uma simplificaçăo desta:

$$
w^{(1-m)}=W^{(1-m)}\left(1+b \cdot e^{-k x}\right)
$$

onde: $w$ = peso ou volume da planta ou parcela ;

$W=$ valor assintótico ou produçăo máxima;

$k=$ taxa de crescimento;

$m=$ constante que determina o ponto de inflexáo;

$b=(w o / W)^{(1-m)}$, e w em $x=0$ é wo;

$x=$ idade ou espaçamento.

O autor náo se preocupa com a retangularidade, haja vista a compensaçăo das árvores ao longo dos anos de crescimento. Esta suposiçăo é confirmada por SALMINEN \& VARMOLA (1993) que năo obtiveram respostas diferenciadas de crescimento (DAP, altura e volume) aos 17 anos para Pinus sylvestris, conduzidos sob diferentes retangularidades em espaçamentos de $2,0 \times 2,0$ $\mathrm{m}, 3,0 \times 3,0 \mathrm{~m}, 3,5 \times 3,5 \mathrm{~m}, 5,0 \times 0,8 \mathrm{~m}, 5,0 \times 1,8 \mathrm{~m}$ e 8,0 $\times 1,53 \mathrm{~m}$.

NAMKOONG (1967), WRIGHT (1976) e PEARCE (1989) recomendam que se investigue as correlaçбes existentes entre parcelas vizinhas, haja visto a competiçăo radicular e aérea, bem como o efeito nas parcelas vizinhas provocado pela morte de plantas. WILKINSON et alii (1983) comentam o uso de análise de covariancia com informaçóes de parcelas vizinhas. DRAPER \& GUTTMAN (1980) ilustram um modelo geral para superficie de resposta no qual se contempla o efeito de uma parcela sobre suas vizinhas. BESAG \& KEMPTON (1986) também mostram modelos para ajustar o efeito de parcelas vizinhas. GOMEZ \& DEDATTA (1972) são mais rigorosos e recomendam eliminar as parcelas adjacentes às falhas, e 
NELDER(1962) lembra que a ocorrencia de 1 falha no delineamento tipo "leque" resulta na perda de 5 observaçoes, a falha e seus 4 vizinhos imediatos.

NELDER (1962) e MEAD (1988) sugerem que se estimem os parámetros da regressáo para diferentes blocos e posteriormente se compare estas estimativas como se constituissem uma amostra aleatória.

LUTWICK et alii (1980) trabalharam com um delineamento sistemático com níveis crescentes de $\mathrm{N}$ e $\mathrm{P}$ aplicados em gramineas, ortogonalmente, num total de 162 combinaçóes, com 2 blocos e em 3 locais. Estabelecem um modelo de $2^{2}$ ordem como superficie de resposta, reconhecendo que apesar do "bias" possivelmente existente, o experimento serviu para avaliar a faixa de dosagens que necessitam de maiores estudos. Usam também gráficos com contornos de produçáo para comparar os efeitos do $\mathrm{N} \mathrm{e} P$ nos 3 locais.

WAHUA \& MILLER (1978) utilizaram o delineamento tipo "leque" num estudo de consorciaçăo de sorgo e soja num arranjo em sub-subparcela onde a parcela é representada pela variedade de sorgo, a subparcela pelos tipos de consorciaçăo e a sub-subparcela representando o espaçamento entre plantas de sorgo. A análise do experimento foi feita com base em regressões tendo como variável independente a densidade de plantio do sorgo.

NELDER (1962), BLEASDALE (1966) e WAHUA \& MILLER (1978) chamam a atençăo para a estimativa de produçăo por área em delineamentos sistemáticos tipo "leque", aconselhando avaliar a opçåo de se trabalhar com apenas urn ou com um conjunto de arcos adjacentes que constituiriarn uma parcela

CLEAVER et alii (1970) estabeleceram experimentos sistemáticos com plantas hortícolas, com gradientes crescentes de 2 nutrientes, de forma ortogonal, concluindo que a existéncia de gradiente de fertilidade que levasse a resultados viezados podia ser testada comparando-se, na análise de variáncia, os quadrados médios das interaçóes simples e duplas dos tratamentos e repetiçoes. Os mesmos autores se utilizam de linhas de iso-produçáa para comparar os efeitos nas diferentes repetiçoes avaliando-se suas similaridades. Comentam ainda que buscam padrós básicos de resposta e que o delineamento sistemático propiciou trabalhar com menor área e ficar mais atento aos detalhes de manejo. Segundo os autores obtiveram-se 
respostas a doses de $\mathrm{P}$ ainda náo testada nos delineamentos tradicionais com pequeno número de tratamentos.

FOX (1973) trabalhando com um delineamento sistemático com gradientes crescentes de 40 niveis de $\mathrm{N}$ em fileiras de milho, com 4 repetiçoes em sentidos opostos, considera cada planta como uma parcela, ocupando todo o experimento uma área de apenas $50 \mathrm{~m}^{2}$. Efetua a análise de variancia de forma tradicional, bem como as regressoes, tendo como variável independente os niveis de $N$ aplicados.

BAUDER et alii (1975) comparam um delineamento sistemático, com 24 niveis crescentes de $\mathrm{N}$ e 8 niveis de umidade no solo dispostos ortogonalmente, com um delineamento em parcela subdividida, com 4 niveis de umidade (parcela) e 5 niveis de nitrogénio (subparcela), o qual demandou uma área 4 vezes maior, para estudar a produçăo de milho em dois locais. Os autores estabelecem as superficies de resposta e efetuam as análises de regressão e variáncia tomando ambos delineamentos como aleatórios. Relatam que os delineamentos levam às mesmas conclusóes finais $\mathrm{e}$ os valores estimados pelas equaçoes dos diferentes delineamentos nâo săo significativamente distintas. Como desvantagem do delineamento sistemático apontam que o menor tamanho das parcelas refletem em maiores variáncias entre as mesmas.

WILLEY \& RAO (1981) utilizaram delineamento sistemático no estudo da consorciaçáo de gráo-de-bico e cártano, buscando obter padrôes básicos de resposta e testaram, numa área de $228 \mathrm{~m}^{2}, 128$ tratamentos distintos, estabelecendo regressões de produção por planta e por área e interpretando o comportamento das duas espécies frente à consorciação.

MEAD (1988) chama a atençăo de que as maiores criticas aos delineamentos sistemáticos com fator continuo se devem: $1^{\circ}$ a uma visăo restrita da experimentação na sua realidade prática, e $2^{\circ}$ devido a falta de métodos de análise que possibilitem utilizar apropriadamente os dados experimentais obtidos nestes delineamentos.

RAO et alii (1990) concluem que a recomendaçăo de delineamentos sistemáticos é dependente do balanço entre a precisão estatistica e a sua praticidade agronòmica 


\subsection{Espaçamento para Eucalyptus dunnii}

O Eucalyptus dunnii é originário da regiăo de Nova Gales do Sul e Queensland, na Austrália, entre as latitudes de $28^{\circ}$ a $30^{\circ} \mathrm{S}$, e altitudes de 300 a $800 \mathrm{~m}$, onde a espécie atinge 30 a 40 metros de altura em solos úmidos e férteis (FAO, 1981). O clima regional apresenta precipitaçăo anual de 1000 a $1500 \mathrm{~mm}$, pequena estaçăo seca de 3 meses no inverno, temperaturas máximas de $29^{\circ} \mathrm{C}$ e minimas de $8^{\circ} \mathrm{C}$, com geadas ocasionais (HILLIS \& BROWN, 1978). A madeira tem uso para serraria, na Austrália, sendo também utilizada para produçăo de celulose no Brasil, e como fonte de energia e carváo (FAO, 1981; PEREIRA et alii, 1986).

Introduzida no Brasil em 1964, a espécie é apta para reflorestamento homogéneo e equianneo no sul do pals, pois suporta temperaturas minimas de $-5^{\circ} \mathrm{C}$ (GOLFARI et alii, 1978). O autor cita, ainda, parcelas experimentais no Paraná com altura média de $32 \mathrm{~m}$ e diámetro à altura do peito (DAP) de $26 \mathrm{~cm}$, aos 7 anos, num espaçamento de $3 \mathrm{~m} \times 3 \mathrm{~m}\left(9 \mathrm{~m}^{2} /\right.$ planta), numa altitude de $900 \mathrm{~m}$ e solos férteis.

A espécie destaca-se, em grande parte do estado do Paraná, pelo seu rápido crescimento e uniformidade dos maciços florestais (EMBRAPA, 1986). Estudando o comportamento de trés procedéncias de E.dunnii no Paraná, PEREIRA et alii (1986) citam produçoes de 133 a $203 \mathrm{~m}^{3} / \mathrm{ha}$ aos 4 anos e meio, em experimento com espaçamento de 3,0 $\times 2,0 \mathrm{~m}$ e 25 plantas úteis por parcela.

MONTEIRO \& CORDEIRO (1983) descrevem o comportamento da espécie frente ao espaçamento num delineamento em blocos casualizados e num arboreto, aos 5 anos. Os 6 tratamentos no delineamento em blocos casualizados, com 4 repetiçסes, foram os de $2,0 \times 2,0 \mathrm{~m}, 2,0 \times 2,5 \mathrm{~m}, 2,5 \times 2,5 \mathrm{~m}, 3,0 \times 2,5 \mathrm{~m}, 3,0$ $\times 3,0 \mathrm{~m}$ e $2,5 \times 1,7 \mathrm{~m}$, variando de 4,0 a $9,0 \mathrm{~m}^{2} /$ planta, tendo cada parcela 36 plantas úteis. Houve diferença significativa entre os tratamentos para as variáveis diâmetro e altura, sendo que no menor espaçamento $(2 \times 2 \mathrm{~m})$ o DAP médio/altura média foi de $10,5 \mathrm{~cm} / 18,6 \mathrm{~m}$, e no maior espaçamento $(3 \times 3 \mathrm{~m})$ de $15,3 \mathrm{~cm} / 21,2 \mathrm{~m}$. Năo houve diferença significativa para volume total, que teve média geral $198,10 \mathrm{~m}^{3} / \mathrm{ha}$. Ao avaliarem o arboreto, obtiveram valores para DAP/altura, no espaçamento $2,0 \times 2,0 \mathrm{~m}$, de $13,1 \mathrm{~cm} / 20,2 \mathrm{~m}$, e no $3,0 \times 3,3 \mathrm{~m}$, de $23,0 \mathrm{~cm} / 26,1 \mathrm{~m}$, superiores àqueles observados no delineamento em blocos casualizados. 


\section{MATERIAL E MÉTODOS}

\subsection{Material}

\subsubsection{Localizaçåo dos Experimentos}

Dois experimentos, um com delineamento em blocos casualizados e o outro com delineamento sistemático tipo "leque", testando espaçamentos de plantio para Eucalyptus dunnii. foram instalados em março de 1988 na fazenda Ibiti, de propriedade da Ripasa SIA Celulose e Papel, situada no município de Itararé, Estado de Săo Paulo.

As coordenadas geográficas locais săo de $24^{\circ} 11^{\prime} \mathrm{S}$ de latitude, $49^{\circ} 08^{\prime}$ $W$ de longitude e 980 metros de altitude.

A fazenda pertence a regiăo administrativa estadual de Sorocaba, a qual possui cerca de 240000 ha de reflorestamentos com Eucalyptus, representando $45 \%$ das florestas corn este género no Estado de São Paulo (KRONKA et alii, 1993).

Os experimentos foram instalados em local de relevo plano e em áreas contiguas (Figuras 7 e 33 -apéndice).

\subsubsection{Caracterização do Material Genético}

A espécie testada foi o Eucalyptus dunnii Maiden, proveniente de um lote de sementes de polinizaçăo aberta, de populaçoes nativas da Austrália. As sementes foram importadas, através da empresa Consulflor Ltda, com lote $n^{\circ} 480$.

As mudas foram produzidas no viveiro da fazenda Fortaleza, lbaté -SP, da Ripasa S/A Celulose e Papel, no sistema de tubetes $\left(50 \mathrm{~cm}^{3}\right)$, tendo como substrato uma mistura de $90 \%$ de casca de eucalipto compostada e $10 \%$ de cinza de 
caldeira de biomassa. As fertilizaçoes de viveiro constituiram-se da aplicaçăo de $10 \mathrm{~kg}$ de super fosfato simples $/ \mathrm{m}^{3}$ do substrato e 4 fertilizaçoes de cobertura, com uma soluçăo preparada à base de $0,5 \mathrm{~kg}$ de sulfato de amóneo e $0,3 \mathrm{~kg}$ de cloreto de potássio / 100 litros d'água, aos 15, 35, 55 e 75 dias.

As mudas foram produzidas em 90 dias, e selecionadas para plantio aquelas com altura entre 30 e $35 \mathrm{~cm}$, vigorosas e sadias.

\subsubsection{Caracterizaçăo do Solo}

O solo local foi classificado por RIZZO (1984) como sendo um latossolo vermelho escuro álico, A moderado, textura argilosa, relevo plano e suave ondulado (Haplic Acrorthox, segundo Soil taxonomy USDA), tendo como material de origem siltitos e argilitos da formaçăo Itararé, profundo e possuindo boa drenagem interna. Esta unidade de mapeamento de solo representava, na época, 23\% das áreas florestais da Empresa.

A descriçăo morfológica do perfil do solo identificou 4 horizontes, até $150 \mathrm{~cm}$ de profundidade, possuindo, em geral, cores bruno avermelhadas (2,5YR 3/4), textura argilosa, e estrutura superficial granular, média, forte, plástica e pegajosa passando a maciça, porosa, plástica e pegajosa em profundidade.

As análises fisicas e de fertilidade do solo, por horizonte, encontram-se nas Tabelas 1 e 2.

TABELA 1. Análise fisica do latossolo vermelho escuro, nos diversos horizontes, antes do preparo de solo (RIZZO, 1984).

\begin{tabular}{|c|c|c|c|c|c|c|}
\hline Horizonte & Profundidade & Areia & Silte & Argila & Densidade & Porosidade \\
\hline nome & $\mathrm{cm}$ & $\%$ & $\%$ & $\%$ & $\mathrm{~g} / \mathrm{cm}^{3}$ & $\%$ \\
\hline $\mathrm{Ap}$ & $000-025$ & 39 & 13 & 48 & 1,33 & 27 \\
\hline $\mathrm{B} 1$ & $025-060$ & 34 & 12 & 54 & 1,16 & 22 \\
\hline $\mathrm{B} 21$ & $060-100$ & 31 & 11 & 58 & 1,20 & 19 \\
\hline $\mathrm{B} 22$ & $100-150+$ & 30 & 12 & 58 & 1,20 & 21 \\
\hline
\end{tabular}


TABELA 2. Análise de fertilidade do latossolo vermelho escuro, nos diversos horizontes, antes do preparo de solo (RIZZO, 1984).

\begin{tabular}{|c|c|c|c|c|c|c|c|c|c|c|c|}
\hline Hor. & Prof. & $\mathrm{pH}$ & $\mathrm{M} . \mathrm{O}$. & $\mathrm{P}$ & $\mathrm{Ca}^{2+}$ & $\mathrm{Mg}^{2+}$ & $\mathrm{K}^{+}$ & $\mathrm{H}^{+}+\mathrm{Al}^{3+}$ & $\mathrm{CTC}$ & $\mathrm{V}$ \\
\hline nome & $\mathrm{cm}$ & $\mathrm{KCl}$ & $\%$ & $\mathrm{ppm}$ & \multicolumn{5}{|c|}{$\mathrm{emg} / 100 \mathrm{~g}$} & $\%$ \\
\hline $\mathrm{Ap}$ & $000-025$ & 3,6 & 3,3 & 2 & 0,38 & 0,50 & 0,19 & 10,72 & 11,81 & 9 \\
\hline $\mathrm{B} 1$ & $025-060$ & 3,7 & 2,4 & 1 & 0,05 & 0,19 & 0,05 & 8,00 & 8,30 & 4 \\
\hline $\mathrm{B} 21$ & $060-100$ & 3,9 & 1,7 & 1 & 0,05 & 0,15 & 0,02 & 6,56 & 6,78 & 3 \\
\hline $\mathrm{B} 22$ & $100-150+$ & 4,6 & 0,9 & 2 & 0,02 & 0,09 & 0,02 & 3,84 & 3,97 & 3 \\
\hline
\end{tabular}

A maior densidade aparente na camada superficial, Tabela 1, se deve à compactaçăo por pisoteio de gado, sendo facilmente removida pelos processos usuais de araçăo e gradagem que antecederam o plantio, estando a densidade aparente natural de $1,2 \mathrm{~g} / \mathrm{cm}^{3}$ numa faixa bastante propicia para o crescimento radicular das plantas. A porosidade e textura, praticamente constantes ao longo do perfil, também se mostram favoráveis ao crescimento de maciços florestais.

Quanto ao aspecto químico, o solo é de baixa fertilidade natural, sendo extremamente ácido, pobre em fósforo e em bases. No entanto, devido aos seus altos teores de matéria orgânica, CTC e argila, possibilita, através de um adequado manejo de fertilizaçăo, sua correçăo nutricional e permitindo que se consigam boas produtividades com materiais genéticos adaptados às condiçóes climáticas regionais.

\subsubsection{Caracterizaçăo Bloclimática}

O clima local é do tipo Cfb, pela classificaçăo de Kóppen e segundo GOLFARI (1978) a área pertence à 4" Regiăo Bioclimática Brasileira possuindo clima submontano, úmido, com chuvas uniformes e auséncia de deficiéncia hidrica ao longo do ano. Corresponde também à 2" Regiâo Bioclimática do Paraná (EMBRAPA, 1986), com uma precipitaçăo média de $1389 \mathrm{~mm} / \mathrm{ano}$, evapotranspiraçăo potencial de 947 $\mathrm{mm} / \mathrm{ano}$, temperatura média anual de $19^{\circ} \mathrm{C}$, e com 0 a 3 geadas por ano ( $\mathrm{RIZZO}$, 1984).

A existéncia de um posto meteorológico na fazenda Ibiti, com coletas diárias de precipitaçăo, temperaturas mínimas e máximas, possibilitou elaborar a Tabela 3. 
TABELA 3. Precipitaçס̃es (Ppt) e Temperaturas médias (Tem) mensais, no periodo de março de 1988 a fevereiro de 1994, no local do ensaio, em Itararé-SP.

\begin{tabular}{|c|c|c|c|c|c|c|c|c|c|c|c|c|c|c|}
\hline Ano & \multicolumn{2}{|c|}{1988} & \multicolumn{2}{|c|}{1989} & \multicolumn{2}{|c|}{1990} & \multicolumn{2}{|c|}{1991} & \multicolumn{2}{|c|}{1992} & \multicolumn{2}{|c|}{1993} & \multicolumn{2}{|c|}{1994} \\
\hline Més & $\begin{array}{l}\mathrm{Ppt} \\
\mathrm{mm}\end{array}$ & $\begin{array}{l}\text { Tem } \\
{ }^{\circ} \mathrm{C}\end{array}$ & $\begin{array}{l}\text { Ppt } \\
\mathrm{mm}\end{array}$ & $\begin{array}{l}\text { Tem } \\
{ }^{\circ} \mathrm{C}\end{array}$ & $\begin{array}{l}\mathrm{Ppt} \\
\mathrm{mm}\end{array}$ & $\begin{array}{l}\text { Tem } \\
{ }^{\circ} \mathrm{C}\end{array}$ & $\begin{array}{l}\text { Ppt } \\
\mathrm{mm}\end{array}$ & $\begin{array}{l}\text { Tem } \\
{ }^{\circ} \mathrm{C}\end{array}$ & $\begin{array}{l}\text { Ppt } \\
\mathrm{mm}\end{array}$ & $\begin{array}{l}\text { Tem } \\
{ }^{\circ} \mathrm{C}\end{array}$ & $\begin{array}{l}\text { Ppt } \\
\mathrm{mm}\end{array}$ & $\begin{array}{l}\text { Tem } \\
{ }^{\circ} \mathrm{C}\end{array}$ & $\begin{array}{l}\text { Ppt } \\
\mathrm{mm}\end{array}$ & $\begin{array}{l}\text { Tem } \\
{ }^{\circ} \mathrm{C}\end{array}$ \\
\hline Jan & & & 223 & 23,4 & 335 & 23,8 & 118 & 23,4 & 100 & 23,9 & 332 & 23,3 & 170 & 22,6 \\
\hline ev & & & 244 & 25,0 & 111 & 25,0 & 161 & 23,0 & 205 & 22,0 & 234 & 22,7 & 93 & 25,6 \\
\hline Mar & 119 & 22,3 & 120 & 28,2 & 114 & 24,0 & $\overline{224}$ & 22,0 & 340 & 21,9 & 128 & 22,8 & & \\
\hline$\overline{A b r}$ & 81 & 19,6 & 35 & 24,3 & 81 & $\overline{22,2}$ & 87 & 20,7 & 100 & 18,7 & 44 & 22,3 & & \\
\hline Mai & 213 & 17,0 & 39 & 17,9 & 65 & 15,6 & 47 & 16,8 & 178 & 18,3 & 101 & 18,6 & & \\
\hline Jun & $5 \overline{9}$ & 14,5 & 66 & 16,5 & 28 & 14,2 & 106 & 16,5 & 18 & 17,2 & 87 & 15,2 & & \\
\hline Jul & $\overline{6}$ & 14,1 & 206 & 19,1 & 160 & $\overline{13,4}$ & 18 & 15,1 & 35 & 17,3 & 47 & 18,3 & & \\
\hline Ago & 0 & 17,8 & 73 & 18,3 & 89 & 16,2 & 48 & 17.4 & 47 & 16.2 & 51 & 16,7 & & \\
\hline Set & 30 & 19,2 & 100 & 20,6 & 110 & 16.7 & 134 & 19,6 & 117 & $18, \overline{2}$ & 188 & 17,1 & & \\
\hline Out & $\overline{117}$ & 19,2 & 102 & 16,1 & 84 & 19,3 & 126 & 20,9 & 135 & 19,4 & $\overline{111}$ & 21,3 & & \\
\hline Nov & 63 & 21,5 & 68 & 18,6 & 90 & 22,0 & 73 & 21,9 & 128 & 20,6 & 87 & 23,9 & & \\
\hline Dez & $15 \overline{9}$ & 23,3 & 238 & 23,4 & 49 & 21,5 & 230 & 23,0 & $5 \overline{3}$ & 22,4 & 185 & 23,7 & & \\
\hline Ano & 847 & 18,9 & 1514 & 21,0 & 1316 & $19, \overline{5}$ & 1372 & 20,0 & 1456 & 19,7 & 1395 & 20,5 & 263 & 24,1 \\
\hline
\end{tabular}

No perido de março 1988 a fevereiro de 1994, foram registradas 3 geadas, que não danificaram as árvores do experimento, em virtude de sua resisténcia natural ao fenómeno (HILLIS \& BROWN, 1978). A distribuiçăo das chuvas e as temperaturas médias mensais indicam que durante todo o periodo de crescimento do ensaio houve condições térmicas e hidricas propicias para o desenvolvimento do E.dunnii, dada a similaridade com sua regiăo de origem (HILLIS \& BROWN, 1978).

A vegetaçăo anterior, no local do experimento, era de campo nativo, com gramineas de altitude, usado extensivamente para pastoreio de gado bovino.

\subsection{Métodos}

\subsubsection{Delineamento em Blocos Casualizados}

O primeiro experimento foi instalado no delineamento convencional, em blocos casualizados, com 5 tratamentos e 4 repetiçóes. Os tratamentos ensaiados, bem como suas relaçóes com área por planta e densidade de plantas por hectare, săo expostos na Tabela 4 
TABELA 4. Tratamentos de espaçamento do E.dunnii, no experimento em blocos casualizados.

\begin{tabular}{|c|c|c|c|}
\hline TRATAMENTO & ESPACAMENTO & ÁREA & DENSIDADE \\
\hline (número) & (m linha $\times$ m planta) & (m²/planta) & (plantas/ha) \\
\hline 1 & $3,00 \times 1,50$ & 4,50 & 2222 \\
\hline 2 & $3,00 \times 2,00$ & 6,00 & 1667 \\
\hline 3 & $3,00 \times 2,50$ & 7,50 & 1333 \\
\hline 4 & $3,00 \times 3,00$ & 9,00 & 1111 \\
\hline $5(1)$ & $3,00 \times 3,00$ & 9,00 & 1111 \\
\hline
\end{tabular}

(1) Plantio em quinquóncio

Os tratamentos 1 a 4 foram implantados sob um arranjo retangular, isto e. as plantas encontram-se alinhadas tanto no sentido das linhas de plantio, como ortogonalmente ao mesmo. Para o tratamento 50 arranjo foi em quinquóncio, ficando as plantas de uma linha defasadas de 1,5 metros em relaçăo às plantas das linhas vizinhas, objetivando melhorar a distribuiçăo das plantas na ocupaçăo da área. Ambos arranjos săo visualizados na Figura 6.

retangular

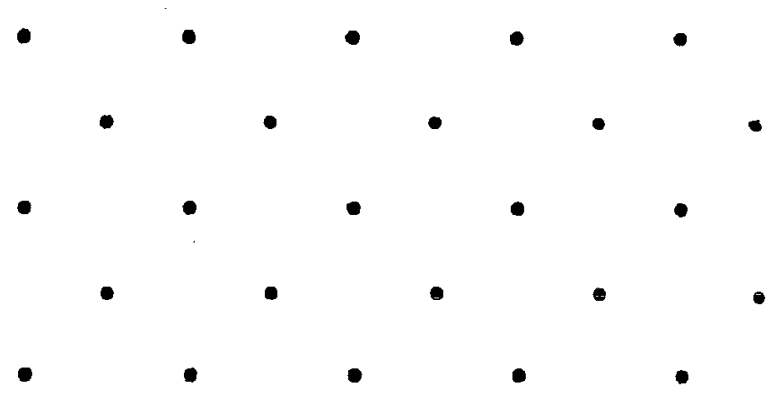

quinquo̊ncio

FIGURA 6. Arranjo de plantio retangular para os tratamentos 1 a 4, e em quinquóncio para o tratamento 5, no experimento em Blocos Casualizados.

As unidades amostrais foram estabelecidas de forma a terem 25 plantas úteis por parcela, 5 linhas por 5 plantas $(5 \times 5)$, e bordaduras duplas a quádruplas. A Tabela 5 caracteriza as parcelas amostrais utilizadas. 
TABELA 5. Plantas úteis e totais, bordaduras entre linhas e entre plantas, área útil e total, das unidades amostrais do experimento em blocos casualizados.

\begin{tabular}{|l|c|c|c|c|c|}
\hline ITEM I TRATAMENTO & $\mathbf{1}$ & $\mathbf{2}$ & $\mathbf{3}$ & $\mathbf{4}$ & $\mathbf{5}$ \\
\hline Espacamento $(\mathrm{m} \times \mathrm{m})$ & $3,00 \times 1,50$ & $3,00 \times 2,00$ & $3,00 \times 2,50$ & $3,00 \times 3,00$ & $3,00 \times 3,00$ \\
\hline Plantas Úteis & 25 & 25 & 25 & 25 & 25 \\
\hline Plantas Totais & 143 & 143 & 121 & 99 & 99 \\
\hline Bordadura Entre Linhas & 3 & 3 & 3 & 3 & 3 \\
\hline Bordadura Entre Plantas & 4 & 4 & 3 & 2 & 2 \\
\hline Área Útil $\left(\mathrm{m}^{2}\right)$ & 112,5 & 150,0 & 187,5 & 225,0 & 225,0 \\
\hline Área Total $\left(\mathrm{m}^{2}\right)$ & 844,5 & 858,0 & 907,5 & 891,0 & 891,0 \\
\hline
\end{tabular}

A Figura 7 ilustra o croqui de instalaçăo do experimento em blocos casualizados, onde os tratamentos foram aleatorizados dentro dos blocos, e do sistemático tipo "Leque".
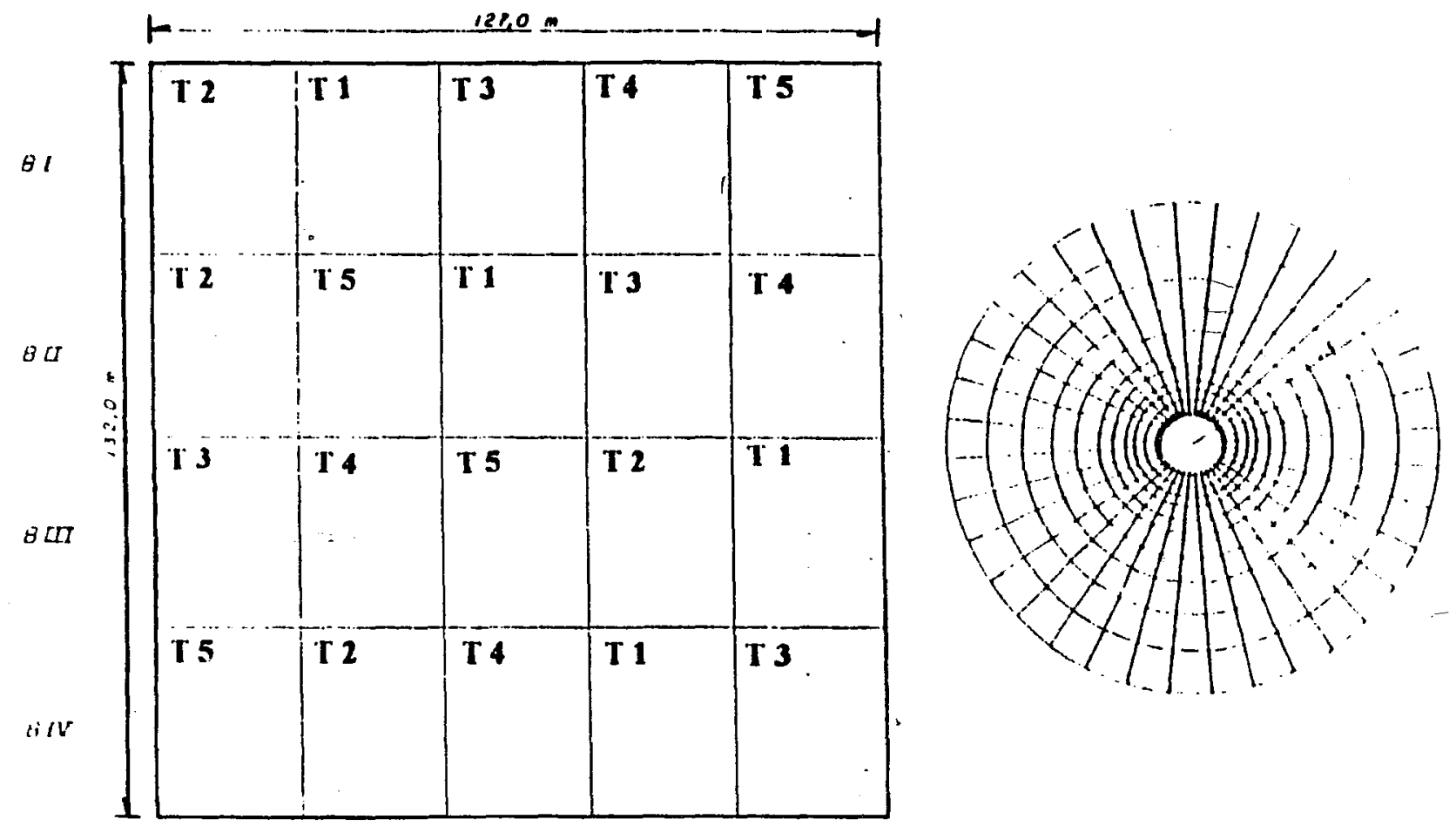

FIGURA 7. Croqui de instalação do experimento em blocos casualizados e sistemático tipo "leque".

A marcaçăo das covas foi efetuada com o uso de teodolito para locaçăo dos vértices externos dos blocos, sendo que internamente foram marcadas as. 
distancias entre linhas e entre plantas com cordas, devidamente identificadas para os diferentes espaçamentos de plantio.

\subsubsection{Delineamento Sistemático Tipo "Leque"}

\subsubsection{Caracterização e Instalação}

O segundo experimento foi instalado em delineamento sistemático tipo "leque", conforme o modelo (IA) proposto por NELDER (1962) (Figura 4). Como exposto por NELDER (1962), e reforçado por BLEASDALE (1966) e CHALITA (1991), este arranjo fica totalmente caracterizado ao definirem-se os valores do raio inicial $r_{0}$ (distância do centro do clrculo à bordadura interna), a razáo da progressăo geométrica dos raios $(\alpha)$ e o ângulo entre os mesmos $(\theta)$. Com estes valores podemos calcular os raios dos tratamentos $\left(r_{1}\right.$ a $\left.r_{n}\right)$, a área associada à cada planta $\left(A_{1}\right.$ a $\left.A_{n}\right)$, que é representada pelo setor circular que a contém, e a retangularidade $(\tau)$, que representa a relaçăo entre as distâncias médias entre plantas nos raios e nos arcos. Estes valores estão ilustrados na Figura 8.

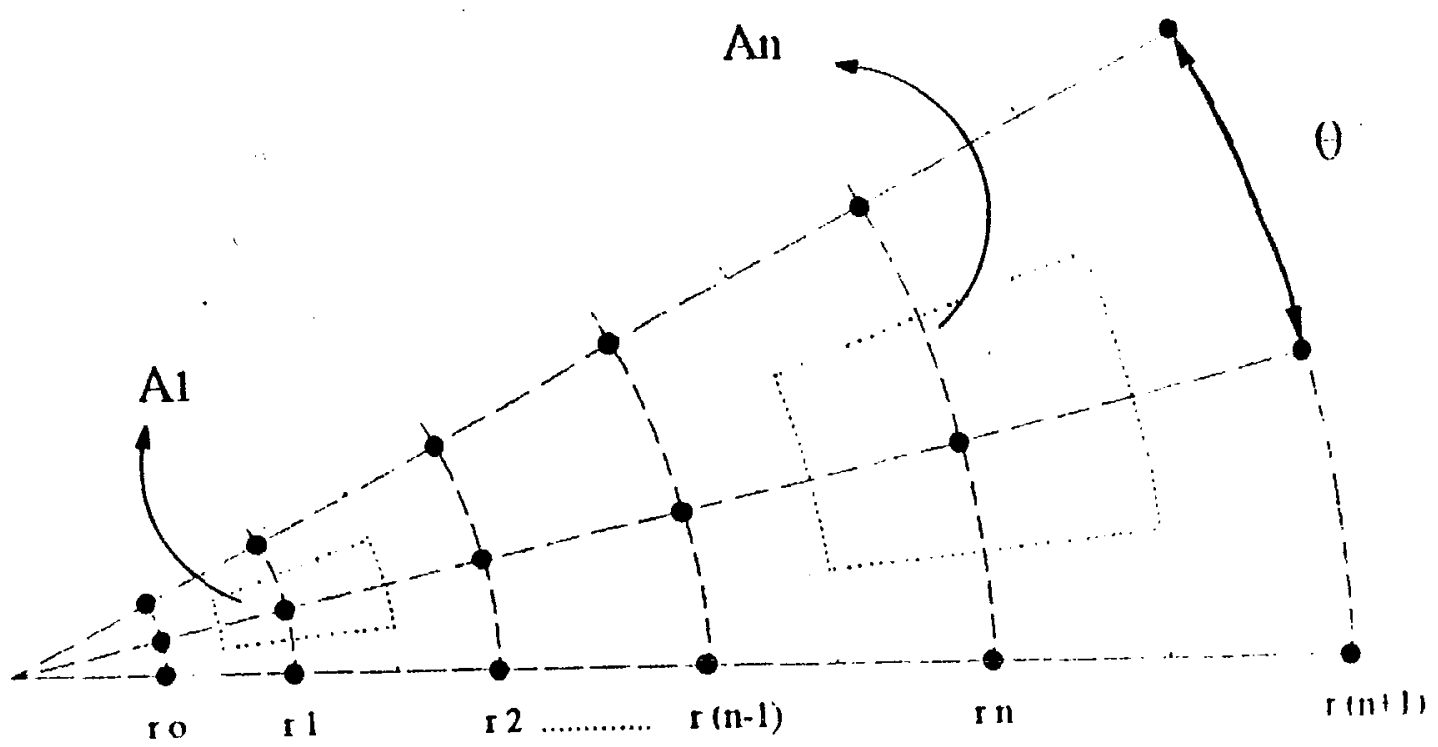

FIGURA 8 . Valores do raio inicial $\left(r_{0}\right)$, raios dos tratamentos $\left(r_{1} a r_{n}\right)$, ángulo entre raios $(\theta)$ e área associada a cada planta $\left(A_{1}\right.$ a $\left.A_{n}\right)$ no delineamento sistemático tipo "leque". 
Dado o grande número de combinaçoes possiveis entre os valores de $r_{0}, \alpha$ e $H$, o número de espaçamentos possiveis é também elevado, de forma que se optou em trabalhar com valores que possibilitassem obter um número de 4 a 5 tratamentos dentro das faixas comerciais de espaçamento para o género Eucalyptus, ou seja de 3 a $12 \mathrm{~m}$ /planta (BALLONI \& SIMÕES, 1980). Assim elaborou-se um programa em computador, na linguagem BASIC, que definidos esses trés valores, fornecia os espaçamentos para 20 arcos concêntricos.

Após inúmeras simulaçoes, optou-se pelos seguintes valores:

$$
r_{0}=6,30 \mathrm{~m}, \alpha=1,21 \text { e } \theta=10^{\circ}(0,17453 \mathrm{rd}) \text {. }
$$

Estes valores propiciaram, entao, obter-se o delineamento em "leque" caracterizado pela Tabela 6.

TABELA 6. Valores da distáncia radial, área por planta e densidade de plantas para 10 espaçamentos (tratamentos) no delineamento sistemático tipo "leque"

\begin{tabular}{|c|c|c|c|}
\hline TRATAMENTO & DISTANCIA RADIAL & AREA & DENSIDADE \\
\hline número & $(\mathbf{m})$ & $\left(\mathbf{m}^{2} /\right.$ planta) & (plantas/ha) \\
\hline 1 & 6,42 & 1,40 & 7143 \\
\hline 2 & 7,78 & 2,05 & 4878 \\
\hline 3 & 9,42 & 3,01 & 3322 \\
\hline 4 & 11,41 & 4,41 & 2268 \\
\hline 5 & 13,82 & 6,47 & 1546 \\
\hline 6 & 16,74 & 9,50 & 1053 \\
7 & 20,27 & 13,93 & 718 \\
\hline 8 & 24,55 & 20,43 & 489 \\
\hline 9 & 29,73 & 29,97 & 334 \\
\hline 10 & 36,00 & 43,95 & 228 \\
\hline
\end{tabular}

Observa-se a grande amplitude de variaçáo dos espaçamentos, de 1,40 a $43,95 \mathrm{~m}^{2} /$ planta, dos quais metade (tratamentos 3 a 7 ), estăo cobrindo faixas comercialmente utilizadas para Eucalyptus, entre 3 a $14 \mathrm{~m}^{2} /$ planta.

Quanto ao número de repetiçőes, pensou-se inicialmente em se utilizar "leques" incompletos, com 8 raios, sendo 6 úteis (2 externos de bordadura), conforme 
arranjo sugerido por NAMKOONG (1966) (Figura 5). No entanto, o aumento das bordaduras, e consequentemente da área experimental, levou a se optar por colocar as 6 repetiçóes formando um círculo completo. Além disso esta disposiçăo possibilita a "compensaçăo" de possiveis gradientes de fertilidade existentes, dada a ortogonalidade mútua entre as repetiçoes, sugerida por HUXLEY (1985) e PEARCÉ (1989). O número de 6 plantas por repetiçăa seguiu as recomendaçóes de NELDER (1962), BLEASDALE (1966) e WAHUA \& MILLER (1978) de se trabalhạ com um conjunto de raios, ao invés de valores individuais por planta, e dos valores mínirnos de 4 plantas úteis por parcela em experimentos com Eucalyptus obtidos por GOMES \& COUTO (1985).

O experimento conta, além da bordadura interna com raio de $5,30 \mathrm{~m}$, com uma bordadura externa com raio de $43,60 \mathrm{~m}$. A Figura 9 ilustra o croqui do experimento.

$87,20 \mathrm{~m}$

FIGURA 9. Croqui de instalaçăo do experimento sistemático tipo "leque". 
A retangularidade $(\tau)$ do delineamento é de 0,91 , ou seja, próxima a unidade. Comparativamente, no delineamento em blocos casualizados a retangularidade variou de 1,0 $(3,0 \mathrm{~m} \times 3,0 \mathrm{~m})$ a 2,0 $(3,0 \mathrm{~m} \times 1,5 \mathrm{~m})$. Desta forma, este fator não foi motivo de preócupaçăo, como bem esclarecem NAMKOONG (1966) e SALMINEN \& VARMOLA (1993).

A locaçăo das covas para plantio foi efetuada com auxlio de um teodolito colocado no centro do clrculo, que iniciou a marcaçăo dos raios a partir do Norte Magnético em 25/02/1988 $\left(r_{0}\right)$, e de uma corda, já devidamente marcada com as distáncias entre plantas, a qual era esticada do centro da figura à cova da bordadura externa $(43,6 \mathrm{~m})$.

\subsubsection{Rearranjo das Parcelas Experimentais}

Em virtude da ocorrencia de falhas e mortalidade de algumas árvores no delineamento sistemático, as plantas vizinhas passaram a ter uma área disponível de crescimento diferente daquela inicialmente estabelecida para os tratamentos (NELDER, 1962). Como estas ocorréncias foram poucas e aleatórias dentro do experimento, optou-se por eliminar da análise experimental todas as plantas vizinhas a estas falhas ou mortes, como propoem GOMEZ \& DEDATTA (1972), ao invés de buscar uma correçăo dos valores observados das variáveis em estudo através de análise de covariância (WILKINSON et alii, 1983; DRAPPER \& GUTTMAN, 1980; BESAG \& KEMPTON, 1986; LAND \& NANCE, 1987).

De modo semelhante, excluiram-se da análise as poucas árvores bifurcadas, isto é, com dois fustes ao nivel do DAP (Diâmetro à Altura do Peito, $1,30 \mathrm{~m}$ em relaçăo ao solo). Este procedimento objetivou também eliminar a necessidade de correçoes para as variáveis estudadas.

Como as falhas, morte e bifurcaçoes năo ocorreram de forma identica em todos os tratamentos, padronizou-se o número de plantas totais por tratamento pela situaçăo mais critica, que foi a da perda de 5 plantas no tratamento 8 , restando portanto 31 plantas por tratamento, das 36 originais. 
Esta depuraçăo das informaçóes levou a rearranjar, de forma bem próxima à proposta original, a concepçăo das repetiçōes e parcelas no delineamento sistemático. Assim as 6 repetiçóes iniciais, por tratamento, com parcelas de 6 plantas, foram rearranjadas em 5 repetiçóes, por tratamento, com parcelas de 6 plantas, totalizando 30 plantas por tratamento.

Portanto, para esta padronizaçăo de 30 árvores por tratamento, fez-se necessário a exclusăo, por sorteio, de diferente número de árvores por tratamento. No item 3.2.4.1, săo detalhadas as árvores eliminadas neste rearranjo.

\subsubsection{Práticas Silviculturais Adotadas}

O preparo de solo para instalaça dos experimentos constitui-se de um revolvimento total da pastagem nativa com grade aradora (discos 32") tracionada por trator de esteira, seguida de uma gradagem de nivelamento (discos 24") com trator de pneu. A Figura 33 ilustra este preparo inicial do solo.

O plantio ocorreu no dia 25 de março de 1988 , com as mudas provenientes do viveiro da Empresa.

A fertilizaçăo foi padronizada por área, à base de $300 \mathrm{~kg} / \mathrm{ha}$ de super fosfato simples granulado, $100 \mathrm{~kg} / \mathrm{ha}$ de NPK 25:0:25 mistura de grânulos e 4 t/ha de calcário calcitico pó.

No delineamento em blocos casualizados o super fosfato simples foi aplicado em sulco, ao longo da linha de plantio, no dia anterior ao plantio. A fertilizaçăo com NPK 25:0:25 fol realizada 25 dias após o plantio, em meia lua distante $30 \mathrm{~cm}$ das mudas. A calagem foi realizada à lanço, em junho de 1991 , quando as plantas estavam com 39 meses.

No delineamento sistemático adotou-se uma dose mínima de $42 \mathrm{~g}$ de super fosfato simples e $14 \mathrm{~g}$ de NPK 25:0:25 na cova, para todos os tratamentos, um dia antes do plantio. A fertilizaçáo restante ocorreu aos 30 dias após o plantio em doses crescentes, ao redor das plantas, de forma a terem todos os tratamentos a mesma quantidade final de fertilizaçăo por área. A calagem foi realizada à lanço, em àrea total, simultaneamente ao delineamento em blocos casualizados. 
Esta fertilizaçăo era, na época, a utilizada pela Empresa em seus plantios comerciais.

No $14^{\circ}$ dia após o plantio foi realizada vistoria nos experimentos para repor mudas nas falhas de plantio.

Desde o plantio (Figura 33), e ao longo de todo a fase de crescimento (Figura 34 - apéndice), os experimentos ficaram livres de matocompetiçăo, devido à baixa infestaçâo de ervas no local e as práticas de capina manual sempre efetuadas quando necessárias.

\subsubsection{Avaliaçoes Dendrométricas}

Os experimentos foram avaliados simultaneamente aos $26,42,48,60$ e 71 meses de idade, por pessoal técnico treinado em mensuraçóes dendrométricas, $\mathrm{e}$ munidos de fichas próprias para anotaçós dos dados. Em cada uma destas avaliações coletaram-se os dados individuais referentes ao DAP e altura total, das árvores úteis, em cada uma das parcelas do experimento em blocos casualizados e do sistemático tipo "leque".

As avaliaçóes foram sempre efetuadas numa mesma sequéncia de caminhamento dentro das parcelas experimentais e anotavam-se ainda as ocorrencias de falhas, mortalidade e bifurcaçoes.

\subsubsection{Falhas e Bifurcaçóes}

As falhas, mortes e bifurcaçóes foram anotadas nas fichas de avaliaçăo de campo de cada um dos experimentos, considerando-se como falha de plantio a inexisténcia da árvore na primeira avaliaçăo, e como mortalidade as futuras falhas ocorridas ao longo do crescimento.

No caso do delineamento em blocos casualizados, com 25 plantas úteis por parcela, a ocorréncia de uma ou outra falha năo gera discrepáncias na estimativa dos parametros populacionais, haja vista a capacidade compensatória das plantas em condição de maciços florestais. 
Para o delineamento sistemático, como já exposto no item 3.2.2.2, houve necessidade de rearranjo do número de repetiçóes em funçăo das falhas e das bifurcaçōes, conforme mostra a Tabela 7 .

TABELA 7. Número do raio das plantas excluidas da análise experimental devido a falha ou morte, sua ou de plantas vizinhas, à bifurcaçăo e árvores sorteadas para padronizar em 30 o número total de árvores por tratamento no delineamento em "leque".

\begin{tabular}{|c|c|c|c|}
\hline TRATAMENTO & FALHAS/MORTES & BIFURCADAS & SORTEIO \\
\hline 1 & $5-6-7$ & & $11-21-28$ \\
\hline$\frac{2}{3}$ & $6-11$ & & $\frac{12-14-20-24}{18-25}$ \\
\hline 4 & $3-10-11-12$ & & $29-36$ \\
\hline 5 & $2-3-4-11$ & & $1-10-12-19$ \\
\hline 6 & $3-22$ & & $6-12-34$ \\
\hline 7 & $21-22-23$ & & $5-11-23-31-33$ \\
\hline 8 & 22 & & 8 \\
\hline 9 & 36 & $17-18-23-25$ & $14-27$ \\
\hline 10 & $1-35-36$ & 16 & $4-7-24$ \\
\hline
\end{tabular}

Assim, após este rearranjo o delineamento sistemático tipo "leque" ficou constiuido de 5 repetiçoes por tratamento, tendo cada parcela 6 plantas, conforme mostra a Tabela 8.

TABELA 8. Número do raio das plantas que compoem as 5 repetiçoes de cada tratamento no delineamento sistemático tipo "leque".

\begin{tabular}{|c|c|c|c|c|c|}
\hline $\begin{array}{l}\text { Repetição } \\
\text { Tratamento }\end{array}$ & 1 & 2 & 3 & 4 & 5 \\
\hline 1 & $1-2-3-4-8-\theta$ & $10-12-13-14-15-16$ & $17-18-19-20-22-23$ & $24-25-26-27-29-30$ & $31-32-33-34-35-36$ \\
\hline$\frac{1}{2}$ & $\longdiv { 1 - 2 - 3 - 4 - 5 - 7 }$ & $8-\theta-10-13-15-1 B$ & $17-1 \bar{Q}-1 \overline{9}-21-22-23$ & $24-26-27-28-29-30$ & $\overline{3} 1-32-33-34-35-36$ \\
\hline 3 & $1-2-4-5-6-7$ & $8-8-13-14-15-16$ & $17-19-20-21-22-23$ & $24-\overline{28-27-28-29-30}$ & $31-32-33-34-35-36$ \\
\hline 4 & $1-5-6-7-8-9$ & $10-12-11-14-15-16$ & $17-18-10-20-21-22$ & $23-24-25-26-27-28$ & $30-31-32-33-34-35$ \\
\hline 5 & $2-4-5-6-7-8$ & $9-11-13-14-15-16$ & $17-18-20-21-23-24$ & $25-26-27-28-29-30$ & $31-32-33-34-35-36$ \\
\hline 6 & $1-2-3-4-5-7$ & $8-9-10-11-13-14$ & $15-16-17-18-19-20$ & $24-25-26-27-28-29$ & $30-31-32-33-35-36$ \\
\hline 7 & $1-2-3-4-6-7$ & $8-2-10-12-13-14$ & $15-16-17-18-12-20$ & $21-24-25-26-27-28$ & $29-30-32-34-35-36$ \\
\hline 8 & $1-2-3-4-5-6$ & $7-0-10-11-12-13$ & $14-15-18-18-20-21$ & $22-24-26-27-28-29$ & $30-3 i-32-33-34-35$ \\
\hline 9 & $2-3-4-5-6-7$ & $8-9-10-11-12-13$ & $15-17-18-19-20-21$ & $22-23-24-25-26-28$ & $29-30-31-32-33-34$ \\
\hline 10 & $\uparrow-2-3-5-6-8$ & $9-11-12-13-14-15$ & $16-17-18-20-21-22$ & $23-25-26-27-28-29$ & $30-31-32-33-34-35$ \\
\hline
\end{tabular}




\subsubsection{Diametro à Altura do Peito (DAP)}

Os DAP, em centimetros, das árvores foram determinados mensurando-se, com fita métrica, as circunferéncias ao nivel do peito (CAP), com precisão de $0,5 \mathrm{~cm}$, e posteriormente convertendo-as para DAP pela divisáo por $\pi$ (pi).

O DAP médio associado a cada parcela experimental foi determinado pela média de todos os DAP da parcela. No delineamento em blocos casualizados o número de plantas mensuradas variou de 25 nas parcelas sem falhas a 23 na parcela com maior número de falhas, tendo o experimento uma sobrevivéncia média de $99 \%$. O número de plantas mensuradas, por parcela, no delineamento sistemático foi 6 .

\subsubsection{Altura}

As alturas totais, em metros, foram determinadas com auxilio do hipsómetro de "Suunto" (FINGER, 1992).

Para cada parcela calculou-se a altura média pela média de todas as alturas totais.

\subsubsection{Volume Individual}

Para se obter os volumes sólidos individuais por planta, com casca, foram abatidas, em diferentes idades, árvores de E.dunnii, do povoamento comercial com espaçamento de $3,0 \mathrm{~m} \times 3,0 \mathrm{~m}$, que circunda o experimento, em classes diamétricas representativas das faixas de diámetro mensuradas no experimento

Estas árvores foram cubicadas de metro em metro, da base de corte até o diámetro minimo de $6 \mathrm{~cm}$, calculando-se o volume de cada seçăo pela fórmula de Smalian, e o volume do ponteiro como se fosse um cone (FINGER, 1992). O volume sólido individual de cada árvore abatida foi entăo determinado por:

$$
v=(\pi / 8) \cdot\left[\left(D_{1}^{2}+D_{n}^{2}\right)+2 \cdot\left(D_{2}^{2}+D_{3}^{2}+\ldots .+D_{n-1}^{2}\right)\right]+(\pi / 12) \cdot D_{n}^{2} \cdot c_{1}
$$


onde:

$v=$ volume sólido individual $\left(\mathrm{m}^{3}\right)$;

$D_{1}, D_{2} \ldots D_{n}=$ diâmetros da árvore nas diversas alturas (m);

$\mathrm{c}=$ comprimento do ponteiro final da árvore $(\mathrm{m})$.

Fez-se entāo o ajuste de equaçōes volumétricas tendo como variável dependente o volume individual, e como variáveis independentes o DAP e altura total dessas ánores. O modelo de equaçăo volumétrica utilizado, dado seus bons ajustes nos povoamentos comerciais da Empresa, foi o de Spurt com variável combinada logaritmica (COUTO \& BASTOS, 1987):

$$
\ln v_{i}=a_{0}+a_{1} \cdot \ln \left(D A P_{i}^{2} \cdot H_{i}\right)+\ln e_{i}
$$

onde:

$v_{i}=$ volume individual da árvore $\mathrm{i}\left(\mathrm{m}^{3}\right)$;

$a_{0}, a_{1}=$ coeficientes da regressáo;

$D A P_{i}=$ diåmetro à altura do peito da árvore $\mathrm{i}(\mathrm{cm}) ;$

$H_{i}=$ altura total da árvore $\mathrm{i}(\mathrm{m})$;

$e_{i}=$ erro associado à observaçăo i.

A Tabela 9 apresenta as estimativas dos parametros das equaçőes ajustadas nas diferentes idades, seus coeficientes de determinaçăo $\left(R^{2}\right)$, testes $F$ da regressáo e o número de árvores utilizadas.

TABELA 9. Ccuficientes das equaçőes volumétricas ajustadas para as diferentes idades, seus coeficientes de determinaçåo $\left(R^{2}\right)$, testes $F$ e o nümero de árvires cubicadas.

\begin{tabular}{|c|c|c|c|c|c|}
\hline IDADE & $\mathbf{a}_{0}$ & $\mathbf{a}_{1}$ & $\mathbf{R}^{\mathbf{2}}$ & $\mathbf{F}(1)$ & Árvores \\
\hline 25 & $-9,704472$ & 0,927806 & 0,998 & $17033^{\star \star}$ & 35 \\
42 & $-9,757822$ & 0,938556 & 0,997 & $16614^{\star \star}$ & 56 \\
\hline 61 & $-10,587227$ & 1,041064 & 0,995 & $14524^{\star \star}$ & 80 \\
\hline 70 & $-10,257052$ & 0,996496 & 0,999 & $20494^{\star \star}$ & 90 \\
\hline
\end{tabular}

(1) ** Significativo ao nivel de $1 \%$ de probabilidade 
Assim, dado seus excelentes ajustes, as equações foram utilizadas, nas suas respectivas idades para se estimar, através do DAP e altura total das árvores, o volume sólido individual, em pé, das mesmas. Para a idade de 48 meses, utilizou-se a equaçăo ajustada para 42 meses, pois as distribuiçoes diamétricas aos 48 e 42 meses năo diferiram substancialmente.

Desta forma, calculou-se o volume individual médio, associado a cada parcela, pela média de todos os volumes sólidos individuais, e expressando o valor final em dm³/árvore.

\subsubsection{5. Área Basal}

Para o cálculo da área basal por hectare somou-se, para cada parcela, as áreas das seçōes transversais ( $\pi$. DAP 2 / 4) de todas as árvores, fazendo-se em seguida a estimativa da área basal por hectare pela fórmula:

$$
A B h=A B p, k ;
$$

onde:

$$
\begin{aligned}
& \mathrm{ABh}=\text { área basal por hectare }\left(\mathrm{m}^{2} / \mathrm{ha}\right) ; \\
& \mathrm{ABp}=\text { área basal da parcela }\left(\mathrm{m}^{2}\right) ; \\
& k=\text { fator de expansáo para hectare }\left(\mathrm{k}=10000 \mathrm{~m}^{2} \text { ( Área da Parcela em } \mathrm{m}^{2}\right) .
\end{aligned}
$$

A Tabela 10 apresenta os fatores de expansåo $(k)$ para os diferentes tratamentos, nos dois experimentos.

TABELA 10. Fator de expansåo para hectare (k), para os diferentes tratamentos, nos delineamentos em blocos casualizados e sistemático tipo "leque".

\begin{tabular}{|c|c|c|c|c|c|c|c|c|c|c|}
\hline DellTr & $\mathbf{1}$ & $\mathbf{2}$ & $\mathbf{3}$ & $\mathbf{4}$ & $\mathbf{5}$ & $\mathbf{6}$ & $\mathbf{7}$ & $\mathbf{8}$ & $\mathbf{9}$ & $\mathbf{1 0}$ \\
\hline Blocos & 88 & 67 & 53 & 44 & 44 & - & - & - & - & - \\
\hline Leque & 1190 & 813 & 554 & 378 & 258 & 175 & 120 & 82 & 56 & 38 \\
\hline
\end{tabular}




\subsubsection{Volume Total}

O volume sólido total por hectare, com casca, foi calculado, para cada parcela, através da soma dos volumes individuais, estimados a partir dos valores de dap e altura de cada árvore pelas equaçóes volumétricas da Tabela 9, multiplicada pelo respectivo fator de expansăo por hectare ( $k$ ) (Tabela 10):

$$
V T h=V T p \cdot k,
$$

onde:

$$
\begin{aligned}
& V T_{h}=\text { volume total por hectare }\left(m^{3} / h a\right) ; \\
& V T_{p}=\text { volume total da parcela }\left(m^{3}\right) ; \\
& k=\text { fator de expansáo para hectare. }
\end{aligned}
$$

\subsubsection{Análise do Delineamento em Blocos Casualizados}

O objetivo básico do delineamento em blocos casualizados foi o de ser o referencial acerca do verdadeiro comportamento das variáveis em estudo (DAP, altura, volume individual, área basal e volume total), em funçăo do espaçamento inicial, nas condiçðes de maciço florestal.

Isto se deve ao fato de todas as árvores mensuradas, em cada parcela, estarem em competiçăo direta, com árvores da parcela e bordaduras, sob o mesmo espaçamento e plantadas num arranjo comercial (Figura 6). Além disso, o cálculo das variáveis área basal e volume total, se basearam em parcelas de 112,5 a $225,0 \mathrm{~m}^{2}$, com fatores de expansăo por hectare (k) próximos.

Em funçăo deste importante papel de "referéncia" na interpretaçăo do delineamento sistemático tipo "leque", avaliou-se 0 comportamento desse experimento, nas diferentes idades, no tocante à variância residual, coeficiente de variaçáo experimental e eficiéncia relativa para todas as 5 variáveis em estudo, considerando-se o modelo estatistico:

$$
y_{i j}=m+t_{i}+b_{j}+e_{i j}
$$


onde:

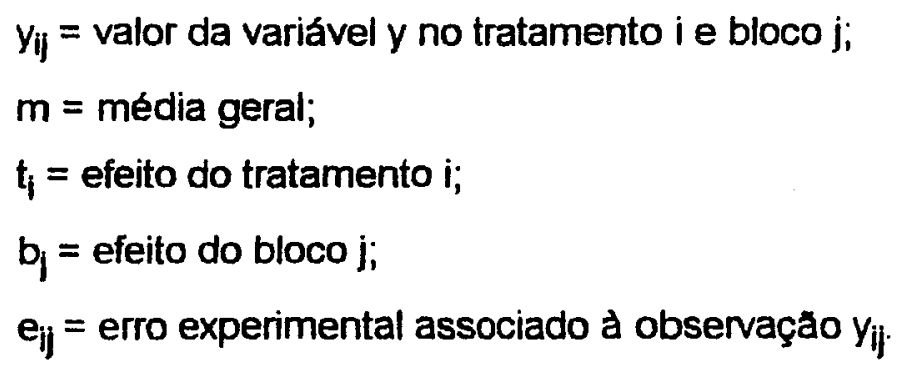

A análise de variancia ficou estabelecida como mostra a Tabela 11.

TABELA 11. Esquema de análise de variáncia do delineamento em blocos casualizados

\begin{tabular}{llll}
\hline Causas de Variaçáo & GL & SQ & QM \\
\hline Tratamentos & $(\mathrm{t}-1)=4$ & SQT & QMT \\
Blocos & $(\mathrm{b}-1)=3$ & SQB & QMB \\
Residuo & $(\mathrm{t}-1)(\mathrm{b}-1)=12$ & SQR & QMR \\
\hline
\end{tabular}

Total (tb-1) $=19$

Assim, para as variáveis DAP, altura, volume individual, área basal e volume total obtiveram-se, para cada idade de avaliaçăo as estimativas da variância residual (QMR) e o coeficiente de variaçăo experimental (CVexp)

$$
C V \exp (\%)=100 \cdot \sqrt{\text { QMR }} / \bar{y}
$$

Para o cálculo da eficiéncia relativa do delineamento em blocos casualizados, comparativamente ao inteiramente ao acaso, utilizou-se a fórmula deduzida por COCHRAN \& COX (1978), com a correçăo quando o número de graus de liberdade do residuo é pequeno:

$$
\operatorname{ER}(\%)=100 \cdot\left[\operatorname{QMR}_{1}\left(n_{1}+1\right)\left(n_{2}+3\right)\right] /\left[\mathrm{QMR}_{\mathrm{b}}\left(\mathrm{n}_{2}+1\right)\left(\mathrm{n}_{1}+3\right)\right]
$$

onde: 
$\mathrm{n}_{1}=$ número de graus de liberdade associados ao resíduo no delineamento em blocos casualizados;

$\mathrm{n}_{2}=$ número de graus de liberdade associados ao residuo no delineamento inteiramente ao acaso;

$Q M R_{i}=$ estimativa da variância residual no delineamento inteiramente ao acaso;

$Q M R_{b}=$ estimativa da variancia residual no delineamento em blocos casualizados

Após estas verificaçóes da uniformidade da área experimental $e$ qualidade do experimento, efetuou-se a análise experimental do mesmo em termos de seus fatores quantitativos (espaçamento). Para isso, analisou-se a exísténcia, ou náo, de efeito linear do espaçamento sobre as variáveis em estudo, fixando-se a ıdade de 71 meses como idade de interesse, em virtude dos plantios comerciais da Empresa com o E.dunnii serem manejados com esta idade de corte para fins de produção de celulose.

A opçáo em se verificar apenas o efeito linear do espaçamento se prende aos seguintes aspectos: 1. A estreita amplitude e pequeno número de espaçamentos em estudo (4 espaçamentos: 4,5;6,0; 7,5 e 9,0 $\mathrm{m}^{2}$ /planta); e 2 . Busca-se apenas verificar tendéncias de comportamento para compará-las ao delineamento sistemático.

Assim, aos 71. meses, para as 5 variáveis em estudo, procedeu-se à análise de regressăo linear, conforme mostra a Tabela 12.

TABELA 12. Esquema de análise de variancia da regressão linear para efeito do espaçamento no delineamento em blocos casualizados.

\begin{tabular}{lclll}
\hline Causa Variaçăo & G.L. & SQ & QM & F \\
\hline Efeito Linear & 1 & & & \\
Desvios da Regressăo & $(t-2)=2$ & SQRL & QMRL & QMRL/QMR \\
Bloco & $(b-1)=3$ & SQB & QMDR & QMDR/QMR \\
Residuo & $(t-1)(b-1)=9$ & SQR & QMR & \\
\hline
\end{tabular}


A seguir, estimaram-se os coeficientes linear $\left(b_{0}\right)$ e angular $\left(b_{1}\right)$ para todas as variáveis, bem como seus erros padrăo e intervalos de confiança bilaterais para um coeficiente de confiança de $95 \%$ de probabilidade $(\alpha=0,05)$, conforme DRAPPER \& SMITH (1981):

$$
\begin{array}{ll}
\hat{b}_{1}=[\Sigma x y-(\Sigma x . \Sigma y / n)] /\left[\Sigma x^{2}-(\Sigma x)^{2} / n\right] & ; s\left(\hat{b}_{1}\right)=\sqrt{Q M R /\left[\Sigma x^{2}-(\Sigma x)^{2} / n\right]} \\
\hat{b}_{0}=\bar{y}-\hat{b}_{1} \cdot \bar{x} & ; s\left(\hat{b}_{0}\right)=\sqrt{Q M R \sum x^{2} /\left[n \cdot\left[\Sigma x^{2}-(\Sigma x)^{2} / n\right]\right\}} \\
I C b_{0}=\hat{b}_{0} \pm \operatorname{t} \cdot s\left(\hat{b}_{0}\right) & ; I C b_{1}=\hat{b}_{1} \pm t \cdot s\left(\hat{b}_{1}\right)
\end{array}
$$

A significância do efeito linear, bem como os intervalos de confiança dos coeficientes $b_{0}$ e $b_{1}$, para todas as variáveis, foram utilizados para fins de comparaçăo com o delineamento sistemático tipo "leque".

\subsubsection{Análise do Delineamento Sistemático Tipo "Leque"}

Por ser um delineamento onde: 1.Năo houve a casualizaçăo dos tratamentos, 2. Nåo se deixaram bordaduras entre tratamentos, e 3. Os fatores de expansăo por hectare $(k)$ são extremamente variáveis; percebe-se que, de fato, ele năo pode ser analisado como se fosse um delineamento aleatório (MEAD, 1988 e PEARCE, 1989). No entanto, a existéncia dos fatores quantitativos crescentes, mesmo que colocados em arranjo sistemático, sugerem o uso de análise de regressão (DAWKINS,1960; SCOTT,1962; NELDER,1962; NAMKOONG,1967; EVERT,1971; WRIGHT,1976; HUXLEY \& MAINGU,1978; HUXLEY,1985; MEAD, 1988 e PEARCE, 1989).

Previamente a esta análise, seguindo proposta de NELDER (1962), CLEAVER et alii (1978) e BAUDER et alii (1978), averiguou-se graficamente o comportamento das variáveis DAP, altura, volume individual, área basal e volume total, frente ao espaçamento, dentro das diferentes repetiçoes, evidenciando-se um comportamento errático de algumas variáveis. Como forma de valorizar esta constataçăo, calcularamn-se as variâncias, por tratamento, eliminando-se, 
justificadamente, aquelas com nitida pertubaçăo, para que năo prejudicassem as regressరoes a serem ajustadas.

Posteriormente, para as 5 variáveis em estudo, na idade de 71 meses, selecionaram-se os tratamentos 4,5 e 6 do delineamento sistemático para ajuste de regressóes lineares, estimativa dos parâmetros $b_{0}$ e $b_{1}$ e obtençăo de seus desvios padrăo e intervalos de confiança para um coeficiente de confiança de $95 \%$ de probabilidade. Esta seleçâo objetivou trabalhar numa faixa de espaçamento, de 4,41 a $9,50 \mathrm{~m}^{2} /$ planta, próxima ao delineamento em blocos casualizados $(4,50$ a 9,00 $\mathrm{m}^{2} /$ planta).

O modelo ajustado foi:

$$
y_{i j}=b_{0}+b_{1} \cdot E_{i}+e_{i j}
$$

onde:

$y_{i}=$ valor da variável y no espaçamento i e repetiçăo j;

$b_{0}, b_{1}=$ coeficientes a serem determinados;

$E_{i}=$ efeito do espaçamento de plantio $i$ ( $m^{2} /$ planta);

$e_{i j}=$ erro experimental associado à observação $y_{i j}$.

A análise de variância para a regressăo se encontra na Tabela 13.

TABELA 13. Esquema de análise variancia da regressâo linear para efeito do espaçamento, nos tratamentos 4,5 e 6, do delineamento sistemático tipo "leque".

\begin{tabular}{|c|c|c|c|c|}
\hline Causa Variaçăo & G.L. & $\overline{S Q}$ & $\mathrm{OM}$ & $F$ \\
\hline $\begin{array}{l}\text { Efeito Linear } \\
\text { Residuo }\end{array}$ & $\begin{array}{r}1 \\
(n-2)=13\end{array}$ & $\begin{array}{l}\text { SQRL } \\
\text { SQR }\end{array}$ & $\begin{array}{l}\text { QMRL } \\
\text { QMR }\end{array}$ & QMRL/QMR \\
\hline
\end{tabular}

Total

$(n-1)=14$

Assim, obtiveram-se as significancias das regressóes ajustadas no delineamento sistemático, bem como os intervalos de confiança dos parâmetros, possibilitando compará-los com as equaçoes ajustadas no delineamento em blocos casualizados, para faixas similares de variaçáo do espaçamento. 


\subsubsection{Análise Comparativa dos Delineamentos}

Inicialmente, compararam-se as variâncias residuais e as significáncias dos coeficientes $b_{0}$ e $b_{1}$ estimados para as variáveis DAP, altura, volume individual, área basal e volume total, bem como seus intervalos de confiança, para ambos experimentos na idade de 71 meses, na faixa de espaçamentos similares.

Apesar das variáveis em estudo terem apresentado a mesma tendéncia de comportamento frente ao espaçamento em ambos delineamentos, constatou-se uma frequente propensáo do delineamento sistemático apresentar uma estimativa do coeficiente linear $b_{0}$ superior ao do delineamento em blocos casualizados. Esta superioridade, até certo ponto encoberta pelas maiores variancias residuais do delineamento sistemático tipo "leque", pode significar, dada a similaridade dos coeficientes angulares, uma superestimativa das variáveis em estudo, para um determinado espaçamento, comparativamente ao delineamento em blocos casualizados.

Assim, constatou-se a possibilidade de se estabeler uma relaçăo entre os valores observados no delineamento sistemático e aqueles do delineamento em blocos casualizados, por representar este último o comportamento da espécie em condiçăo de maciço florestal.

Esta relaçăo é de grande interesse pois possibilita estimarem-se valores de DAP, altura, volume individual, área basal e volume total para povoamentos de E.dunnii, em condiçóes de maciço florestal, em espaçamentos que năo foram testados no delineamento em blocos casualizados. Com isso, dispensar-se-ia a necessidade de nova experimentaçăo num delineamento aleatório, na faixa de espaçamento considerada de interesse, como recomendam os pesquisadores para culturas agricolas (HUXLEY, 1985; PEARCE, 1989 e RAO et alii, 1990).

O modelo determinístico entåo almejado foi:

$$
y_{b}(x)=y_{s}(x)+c(x)
$$

onde: 
$y_{b}(x)=$ valor da variável y no delineamento em blocos casualizados no espaçamento $x$;

$Y_{s}(x)=$ valor da variável y no delineamento sistemático tipo "leque" no espaçamento $x$;

$c(x)=$ fator de correçăo entre delineamento sistemático tipo "leque" e o em blocos casualizados para o espaçamento $x$.

Para obtençăo deste modelo fez-se necessário estabelecer: 1. Uma equaçăo de regressáo $\left(y_{S}(x)\right)$ para toda a faixa de espaçamento do delineamento sistemático $\left(1,40\right.$ a $43,95 \mathrm{~m}^{2} /$ planta) e 2 . Uma regra de ajuste entre os delineamentos $(c(x))$.

$\mathrm{Na}$ primeira etapa avaliaram-se diferentes modelos para ajustar as variáveis dependentes (DAP, altura, volume individual, área basal e volume total) em funçăo da variável independente, o espaçamento ( $E$, em $\mathrm{m}^{2} /$ planta), como mostra a Tabela 14.

TABELA 14. Equações de resposta ao espaçamento (E) testadas para as 5 variáveis em estudo $(V)$, no delineamento sistemático tipo "leque"

\begin{tabular}{|c|l|l|}
\hline $\begin{array}{c}\text { MODELO } \\
1\end{array}$ & $\begin{array}{c}\text { DAP, Altura, Volume individual } \\
y=a_{0}+a_{1} \cdot E\end{array}$ & $y=a_{0}+a_{1} \cdot E$ \\
\hline 2 & $y=a_{0}+a_{1} \cdot E+a_{2} \cdot E^{2}$ & $y=a_{0}+a_{1} \cdot E+a_{2} \cdot E^{2}$ \\
\hline 3 & $y=a_{0}+a_{1} \cdot E+a_{2} \cdot E^{2}+a_{3} \cdot E^{3}$ & $y=a_{0}+a_{1} \cdot E+a_{2} \cdot E^{2}+a_{3} \cdot E^{3}$ \\
$4 e 5$ & $y-1=a_{0}+a_{1} \cdot E^{-1}$ & iny $=a_{0}+a_{1} \cdot E$ \\
\hline
\end{tabular}

Estes modelos foram escolhidos, após observação do comportamento geral de cada variável frente ao espaçamento (Figuras 11, 12, 13, 14 e 15), pela sua simplicidade de ajuste e utilizaçăo (1.linear, 2.quadrático e 3.cúbico) e com base nas propostas de HOLLIDAY (1960), NELDER (1962) e BLEASDALE (1966) (4. inversa e 5.logarítmica). Optou-se por utilizar como variável independente o espaçamento, em $\mathrm{m}^{2}$ /planta, ao invés da densidade de plantas por hectare, para năo se trabalhar com coeficientes estimados muito pequenos. 
As melhores regressóes foram eleitas considerando-se, concomitantemente, seus valores de coeficiente de determinaçăo $\left(R^{2}\right)$, valor do teste F e soma de quadrados da variável original [ yi -yi ] $]^{2}$ (SQ).

$\mathrm{Na}$ segunda etapa, relativa ao fator de correçăo, foi solucionada considerando-se os seguintes pontos: 1. O valor médio da variável no delineamento em blocos casualizados, foi considerado como sendo o maior desvio entre as estimativas do delineamento em blocos casualizados $e$ as estimativas dó delineamento sistemático tipo "leque" (Figura 10); 2. Considerou-se a existencia de uma convergência de resposta para ambos delineamentos no tratamento 10 do delineamento sistemático (43,95 $\mathrm{m}^{2} /$ planta), na idade de 71 meses, isto $e$, neste espaçamento o desvio seria minimo, e igual a zero; 3 . Os desvios na faixa compreendida entre 7,2 e $43,95 \mathrm{~m}^{2} /$ planta, seriam decrescentes, em funçăo da suposta convergéncia; e 4.0 detalhamento da forma e pontos de convergéncia, para cada variável, deveria ser efetuado posteriormente, num aprofundamento do estudo.

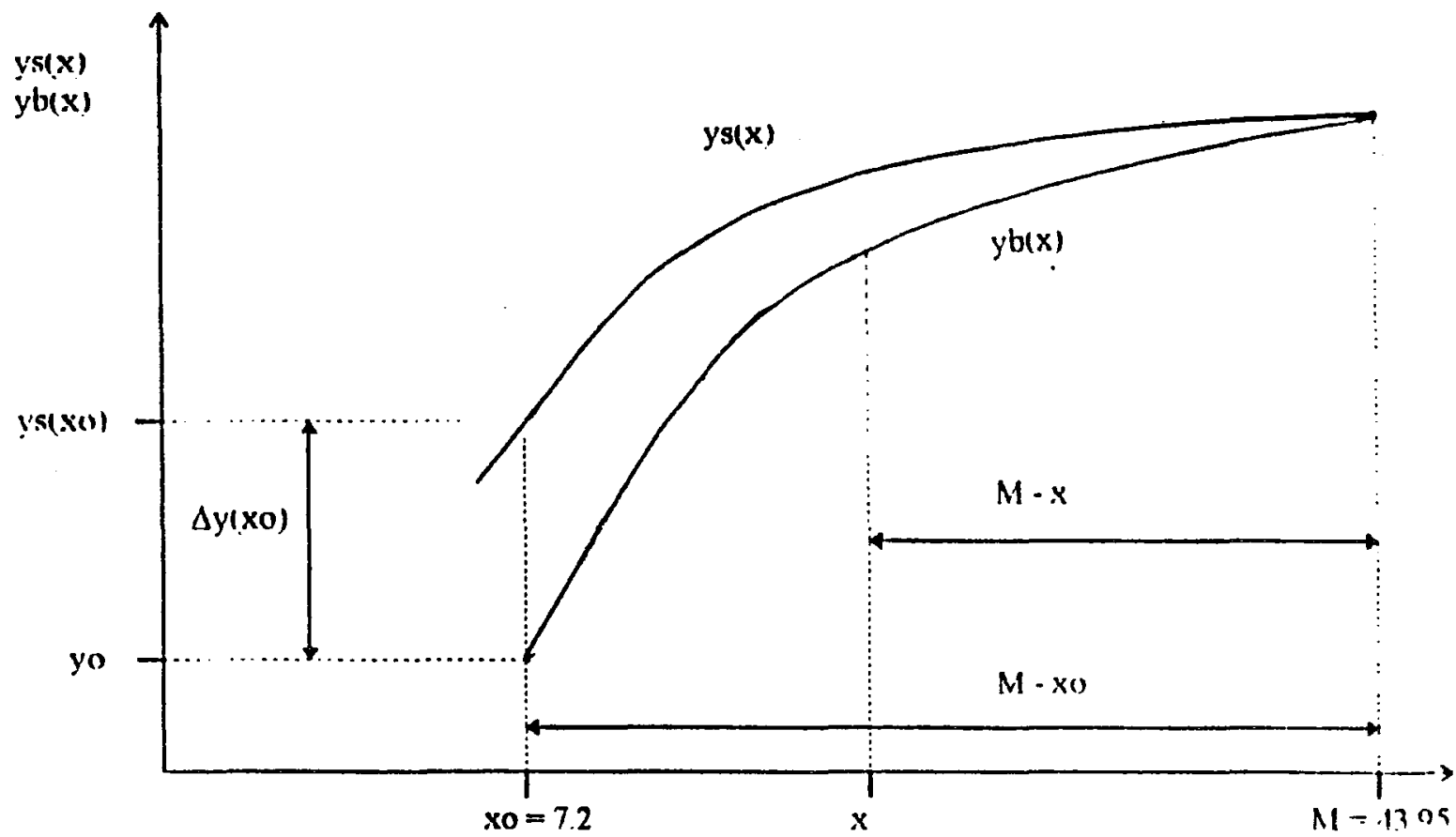

FIGURA 10. Ajuste da equaçăo, das variáveis em estudo, para o delineamerito em blocos casualizados $\left(Y_{b}\right)$ em função do espaçamento $(x)$, e com base nas equaçóes determinadas para o delineamento sistemático tipo "leque" $\left(y_{s}\right)$ e convergéncia no espaçamento de $43,95 \mathrm{~m}^{2} / \mathrm{planta}$ 
A consideraçăo de que no espaçamento de 43,95 $\mathrm{m}^{2}$ /planta, na idade de 71 meses, ambos delineamentos teriam as mesmas estimativas, se embasa na caracteristicas assintóticas dos valores de DAP, altura e volume individual (Tabelas 21,22 e 23 e Figuras 11, 12 e 13) onde se depreende que para este espaçamento, e idade, as árvores estấo crescendo sem competiçăo, independentemente do tipo de delineamento a que estăo submetidas.

Pode-se entâo obter as equaçoes finais, que estimam as variáveis de interesse, em condiçoes de maciço florestal, em funçăo de espaçamentos bastante amplos (7,20 a 43,95 $\mathrm{m}^{2} /$ planta), obtidos em delineamento sistemático tipo "leque" e corrigidos, para a condição de maciços florestais, pela utilizaçăo das parcelas do delineamento em blocos casualizados como "referéncia".

Assim, obtiveram-se as equaçסes para as variáveis em estudo, no delineamento em blocos casualizados (Figura 10), por:

$$
y_{b}(x)=y_{s}(x)-\frac{\Delta y\left(x_{0}\right) \cdot(M-x)}{\left(M-x_{0}\right)}
$$

e, desde que xo $=7,20 \mathrm{~m}^{2} /$ planta e $M=43,95 \mathrm{~m}^{2} /$ planta tem-se:

$$
y_{b}(x)=y_{s}(x)-\left[y_{s}(x o)-y_{0}\right] \cdot(43,95-x)
$$

$(43,95-7,20)$

onde

$y_{b}(x)=$ valor estimado para a variável $y$ no delineamento em blocos casualizados (maciço florestal) no espaçamento $x$;

$y_{s}(x)=$ valor estimado para a variável $y$ no delineamento sistemático tipo "leque" no espaçamento $x$;

$y_{s}(x o)=$ valor estimado para a variável y no delineamento sistemático tipo "leque" no espaçamento xo $=7,20 \mathrm{~m}^{2} /$ planta;

yo = valor médio de y no delineamento em blocos casualizados, aos 71 meses; $x=$ espaçamento de plantio, variando entre 7,20 e $43,95 \mathrm{~m}^{2} /$ planta. 


\section{RESULTADOS E DISCUSSÃO}

\subsection{Delineamento em Blocos Casualizados}

O delineamento em blocos casualizados ocupou uma área total de $16764 \mathrm{~m}^{2}$, sendo $13164 \mathrm{~m}^{2}(79 \%)$ referentes às bordaduras (Figura 7 ). A sobrevivéncia aos 71 meses foi de $99 \%$, havendo, no mínimo, 23 plantas úteis mensuráveis por parcela, das 25 possiveis.

As Tabelas 15, 16, 17, 18 e 19 sumarizam os valores médios obtidos, por tratamento e idade, das variáveis DAP, altura, volume individual, área basal e volume total no experimento em blocos casualizados

TABELA 15 DAP médio (cm), por tratamento, nas diferentes idades de avaliaçăo do E.dunnii, no delineamento em blocos casualizados.

\begin{tabular}{|c|c|c|c|c|c|}
\hline $\begin{array}{c}\text { Tratamento } \\
\text { (m) }\end{array}$ & \multicolumn{5}{|c|}{ IDADE (meses) } \\
\cline { 2 - 6 } & $\mathbf{2 6}$ & $\mathbf{4 2}$ & $\mathbf{4 8}$ & $\mathbf{6 0}$ & $\mathbf{7 1}$ \\
\hline$\frac{1-4,5}{2-6,0}$ & 7,97 & 10,40 & 10,67 & 11,43 & 12,03 \\
\hline $3-7,5$ & 8,62 & 11,55 & 11,88 & 12,77 & 13,48 \\
\hline $4-9,0$ & 9,27 & 12,85 & 13,36 & 14,38 & 15,22 \\
\hline $5-9,0$ & 9,64 & 13,55 & 14,07 & 15,10 & 16,00 \\
\hline 9,70 & 13,63 & 14,20 & 15,41 & 16,24 \\
\hline
\end{tabular}

TABELA 16. Altura média $(m)$, por tratamento, nas diferentes idades de avaliaçăo do E.dunnii, no delineamento em blocos casualizados

\begin{tabular}{|c|c|c|c|c|c|}
\hline Tratamento & \multicolumn{5}{|c|}{ IDADE (meses) } \\
\hline (m²/planta) & 26 & 42 & 48 & 60 & 71 \\
\hline $1-4,5$ & 10,12 & 14,54 & $15,8 \overline{4}$ & 18,73 & 19,11 \\
\hline $2-6,0$ & 10,07 & 15,10 & 16,60 & 19,58 & $\overline{20,26}$ \\
\hline $3-7,5$ & 10,00 & 15,46 & 17,20 & 20,42 & 21,04 \\
\hline $4-9,0$ & 984 & 15,38 & 16,93 & 20,32 & 20,98 \\
\hline $5-9,0$ & 10,01 & 15,65 & 17,41 & 21,20 & 21,84 \\
\hline
\end{tabular}


TABELA 17. Volume individual ( $\mathrm{dm}^{3}$ /árvore), por tratamento, nas diferentes idades de avaliaçåo do E.dunnii, no delineamento em blocos casualizados.

\begin{tabular}{|c|c|c|c|c|c|}
\hline Tratamento & \multicolumn{5}{|c|}{ IDADE (meses) } \\
\hline ( $^{2}$ /planta) & $\mathbf{2 6}$ & $\mathbf{4 2}$ & $\mathbf{4 8}$ & $\mathbf{6 0}$ & $\mathbf{7 1}$ \\
\hline $1-4,5$ & 26,32 & 63,37 & 72,39 & 95,48 & 105,55 \\
\hline $2-6,0$ & 29,37 & 77,00 & 90,94 & 123,12 & 137,28 \\
\hline $3-7,5$ & 33,46 & 96,47 & 115,07 & $163, \frac{2}{26}$ & 181,57 \\
\hline $4-9,0$ & 34,93 & 103,38 & 121,85 & 175,33 & 193,89 \\
\hline $5-9,0$ & 36,27 & 107,28 & 128,21 & 187,98 & 205,44 \\
\hline
\end{tabular}

TABELA 18. Área basal ( $\left.\mathrm{m}^{2} / \mathrm{ha}\right)$, por tratamento, nas diferentes idades de avaliaçâo do E.dunnii, no delineamento em blocos casualizados.

\begin{tabular}{|c|c|c|c|c|c|}
\hline Tratamento & \multicolumn{5}{|c|}{ IDADE (meses) } \\
\hline (m) 2 /planta) & $\mathbf{2 6}$ & $\mathbf{4 2}$ & $\mathbf{4 8}$ & $\mathbf{6 0}$ & $\mathbf{7 1}$ \\
\hline $1-4,5$ & 11,62 & 20,01 & 21,13 & 24,03 & 26,68 \\
\hline $2-6,0$ & 9,92 & 17,95 & 19,36 & 22,11 & 24,71 \\
\hline $3-7,5$ & 9,23 & 17,91 & 19,40 & 22,53 & 25,39 \\
\hline $4-9,0$ & 8,17 & 16,20 & 17,52 & 20,25 & 22,77 \\
\hline $5-9,0$ & 8,39 & 16,64 & 18,08 & 21,03 & 23,45 \\
\hline
\end{tabular}

TABELA 19. Volume total $\left(\mathrm{m}^{3} / \mathrm{ha}\right)$, por tratamento, nas diferentes idades de avaliaçăo do E.dunnii, no delineamento em blocos casualizados.

\begin{tabular}{|c|c|c|c|c|c|}
\hline Tratamento & \multicolumn{5}{|c|}{ IDADE (meses) } \\
\hline (m²/planta) & 26 & 42 & 48 & 60 & 71 \\
\hline $1 \cdot 4,5$ & 58,50 & 140,83 & 160,86 & 212,17 & 234,48 \\
\hline $2-6,0$ & 48,95 & 128,33 & 151,57 & 205,19 & 228,67 \\
\hline $3-75$ & 44,62 & $128, \overline{62}$ & $15 \overline{4}, \overline{3}$ & 217,69 & 241,76 \\
\hline$\overline{4}-\overline{9}, \overline{0}$ & $38, \overline{81}$ & 114,86 & 135,39 & 194,81 & 215,20 \\
\hline $5-\overline{9}, \overline{0}$ & 40,30 & 119,19 & 142,46 & 208,86 & 228,02 \\
\hline
\end{tabular}

Os valores observados nas Tabelas 15 a 19 evidenciam o bom desenvolvimento do E.dunnii nas condiçoes locais de solo (Tabelas 1 e 2) e clima (Tabela 3), obtendo-se, aos 71 meses, incremento médio anual de $39 \mathrm{~m}^{3 /} / \mathrm{ha}$ ano, confirmando a potencialidade da espécie para zonas edafoclimáticas similares a esta, conforme relatam GOLFARI et alii (1978), PEREIRA et alii (1986) e EMBRAPA (1986) 
O DAP médio/altura média nos espaçamentos de 4,5 e $9,0 \mathrm{~m}^{2} /$ planta aos 60 meses, respectivamente de $11,43 \mathrm{~cm} / 18,73 \mathrm{~m}$ e $15,26 \mathrm{~cm} / 20,76 \mathrm{~m}$, săo quase que ideriticos aos encontrados por MONTEIRO \& CORDEIRO (1983), que citam valores de $10,5 \mathrm{~cm} / 18,6 \mathrm{~m}$ para 4,0 m2/planta e $15,3 \mathrm{~cm} / 21,2 \mathrm{~m}$ para $9,0 \mathrm{~m}^{2} /$ planta. Observa-se portanto, que os resultados advindos desta experimentaçăo encontram vasta área geográfica de aplicaçăo, no que se refere à produçăo de madeira para energia (PEREIRA et alii, 1986), celulose e serraria (HILLIS \& BROWN, 1978).

$\mathrm{Na}$ Tabela 20 sáo apresentados os valores do quadrado médio do residuo, teste $F$ para tratamento, coeficiente de variaçăo experimental e eficiéncia relativa do delineamento em blocos casualizados, para as 5 variáveis em estudo, nas diferentes idades de avaliação.

TABELA 20. Quadrado médio do resIduo (QMR), teste $F$ para tratamento, coeficiente de variaçăo experimental (CV) e eficiéncia relativa (ER) do delineamento em blocos casualizados, para as 5 variáveis em estudo, nas diferentes idades.

\begin{tabular}{|c|c|c|c|c|c|c|}
\hline Estatistica & $\frac{\text { IDADE }}{\text { (meses) }}$ & $\begin{array}{l}\text { DAP } \\
(\mathbf{c m})\end{array}$ & $\frac{\text { ALTURA }}{(m)}$ & $\begin{array}{c}\text { V.IND. } \\
\left(\mathrm{dm}^{3} / \mathrm{pl} .\right)\end{array}$ & $\frac{\text { A.BASAL }}{\left(m^{2} / h a\right)}$ & $\frac{\text { V.TOTAL }}{\left.\text { (m } \mathrm{m}^{3} / \mathrm{ha}\right)}$ \\
\hline & 26 & 0,1046 & 0,1286 & 5,26 & 0,3144 & 12,60 \\
\hline & 42 & 0,1384 & 0,1690 & 25,61 & 0,7302 & 53,13 \\
\hline QMR & 48 & 0,1326 & 0,2604 & 54,70 & 1,0521 & 109,71 \\
\hline \multirow[t]{2}{*}{ (12 gl) } & 60 & 0,2024 & 0,3016 & 164,86 & 1,7948 & 309,19 \\
\hline & 71 & 0,2168 & 0,4411 & 224,48 & 2,1689 & 396,38 \\
\hline \multirow{5}{*}{$F(1)$} & 26 & $20,62^{\star \star \star}$ & $0,34^{\mathrm{ns}}$ & 12,94 *ᄎ & 24,63 * & $\overline{19}, \overline{90}$ ** \\
\hline & 42 & $56,09 * \star$ & $4,43^{\star}$ & $54,49 * \star$ & 12,06 ** & $7,57^{\star \star}$ \\
\hline & 48 & $69,73^{* \star}$ & $5,78^{\text {** }}$ & 39,91 ** & 7,42 ** & 3,60 * \\
\hline & 60 & 55,71 ** & 11,61 ** & $36,10^{\star \star}$ & $4,70^{*}$ & $0,95 \mathrm{~ns}$ \\
\hline & 71 & $59,55^{* \star}$ & $9,50^{\star \star}$ & $31,39 \star \star \star$ & 4,44 * & $0,96 \mathrm{~ns}$ \\
\hline \multirow{5}{*}{ CV (\%) } & 26 & 3,6 & 3,6 & 7,1 & 5,9 & 7,7 \\
\hline & 42 & 3,0 & 2,7 & 5,6 & 4,8 & 5,7 \\
\hline & 48 & 2,8 & 3,0 & 7,0 & 5,3 & 7,0 \\
\hline & 60 & 3,2 & 2,7 & 8,6 & 6,1 & 8,4 \\
\hline & 71 & 3,1 & 3,2 & 9,1 & 5,9 & 8,6 \\
\hline \multirow{5}{*}{ ER $(\%)$} & 26 & 85 & 83 & 86 & 85 & 105 \\
\hline & 42 & 82 & 87 & 100 & 102 & 102 \\
\hline & 48 & 84 & 104 & 97 & 98 & 100 \\
\hline & 60 & 87 & 104 & 95 & 103 & 98 \\
\hline & 71 & 85 & 92 & 99 & 98 & 101 \\
\hline
\end{tabular}

(1) * Significativo a $5 \%$ de probabilidade. "* Significativo a $1 \%$ de probabilidade. ns Năo Significativo 
Percebe-se, analisando a Tabela 20, que os valores do teste $F$, para as variáveis em estudo, tiveram comportamentos distintos, ao longo do crescimento das árvores. Assim, para o DAP e volume individual, os valores de F foram sempre altamente significativos, em funçăo de serem variáveis individuais extremamente influenciáveis, ao longo do crescimento das plantas, pela densidade do povoamento (SMITH, 1958 e ASSMANN, 1970). Para a altura, as diferenças entre tratamentos só passaram a ser altamente significativas a partir dos 48 meses, quando as alturas médias nos espaçamentos mais fechados passaram a ser inferiores aos demais, mostrando ser o E.dunnii uma espécie sensivel à competiçăo intra-especlfica (BALLONI \& SIMÕES,1980).

No tocante às variáveis expressas em termos de produçăo por hectare (área basal e volume total), observa-se que as mesmas passam de altamente significativas, nas idades mais jovens, para pouco ou năo significativas nas idades de 5 a 6 anos. Este fato se deve ao efeito compensatório das árvores, que crescem individualmente mais, quando em menores densidades. Assim, a medida que o povoamento envelhece os tratamentos com menor densidade inicial váo alcançando, em termos de produçăo por área, os implantados com maior densidade, desaparecendo a diferença entre tratamentos (EVERT, 1971) e atingindo-se a produçâo máxima potencial de área basal e volume do sitio (ASSMANN 1970; SCHENEIDER, 1993).

Ainda pela Tabela 20, observa-se que o experimento apresenta, ao longo de todo o seu crescimento, e para as 5 variáveis em estudo, baixissimos coeficientes de variaçáo experimental para experimentaçăo de campo. Estes valores confirmam a expectativa inical de homogeneidade da área experimental, plana e uniforme (Figura 33), e săo reflexos também da excelente sobrevivéncia (99\%). condiçơes climáticas favoráveis (Tabela 3) e controle de matocompetiçăo (Figuras 33 e 34).

Esta uniformidade pode ainda ser constatada pela eficiência relativa (ER\%) do delineamento em blocos casualizados, comparativamente ao inteiramente ao acaso, pois para as 5 variáveis em estudo, em todas as idades, a eficiéncia variou 
de 82 a 104\%, mostrando que o experimento dispensaria o controle local através dos blocos (COCHRAN \& COX, 1978).

A uniformidade da área experimental, e os cuidados nos tratos culturais, certamente encontrados no experimento sistemático tipo "leque" contiguo, săo fundamentais para a correta instalaçăo e utilizaçăo deste delineamento, evitando a existéncia de gradiente de fertilidade viciando as estimativas dos efeitos dos tratamentos e o inflacionando do erro experimental (NELDER, 1962; HUXLEY, 1985)

\subsubsection{Análise de Regressão Linear}

A Tabela 21 fornece o teste $F$ para o efeito linear do espaçamento e desvio da regressão, a estimativa dos parametros $b_{0}$ e $b_{1}$, e seus respectivos intervalos de confiança a $95 \%$ de probabilidade, para as 5 variáveis em estudo, aos 71 meses.

TABELA 21. Valores do teste $F$ para regressăo e desvio da regressão, estimativas dos parâmetros $b_{0}$ e $b_{1}$ da regressâo linear e intervalos de confiança para $95 \%$ de probabilidade, das 5 variáveis em estudo, no delineamento em blocos casualizados, para E. dunnii, aos 71 meses.

\begin{tabular}{|c|c|c|c|c|c|c|}
\hline Valor & (1) & DAP & ALTURA & V.IND. & A.BASAL & V.TOTAL \\
\hline & & $(\mathrm{cm})$ & (m) & $\left(\mathrm{dm}^{3} / \mathrm{pl}\right)$ & $\left(m^{2} / h a\right)$ & $\left(m^{3} / h a\right)$ \\
\hline $\mathrm{F}$ & Regr & $234,64^{\text {n* }}$ & $33,03^{\bar{*}}$ & $121,92^{* *}$ & $17,76^{\star \star \star}$ & $3,85 \overrightarrow{n s}$ \\
\hline$F$ & Desv & $1,20 \mathrm{~ns}$ & $1,65 \mathrm{~ns}$ & $1,21^{n s}$ & $1,16 \overline{n s}$ & $0,98 \mathrm{~ns}$ \\
\hline$b_{0}$ & $\begin{array}{l}\text { li } \\
\text { es } \\
\text { is }\end{array}$ & $\begin{array}{l}7,119 \\
8,030 \\
8,941\end{array}$ & $\begin{array}{l}15,727 \\
17,134 \\
18,540\end{array}$ & $\begin{array}{l}-19,236 \\
12,487 \\
44,209\end{array}$ & $\begin{array}{l}26,624 \\
29,717 \\
32,809\end{array}$ & $\begin{array}{l}205,298 \\
247,117 \\
288,937\end{array}$ \\
\hline$b_{1}$ & $\begin{array}{l}\text { li } \\
\text { es } \\
\text { is }\end{array}$ & $\begin{array}{l}0,789 \\
0,912 \\
1,035\end{array}$ & $\begin{array}{l}0,298 \\
0,488 \\
0,678\end{array}$ & $\begin{array}{l}16,866 \\
21,147 \\
25,429\end{array}$ & $\begin{array}{l}-1,128 \\
-0,711 \\
-0,294\end{array}$ & $\begin{array}{l}-8,074 \\
-2,429 \\
3215\end{array}$ \\
\hline
\end{tabular}

(1) li $_{\text { }}$ limite inferior, es $=$ valor estimado, is $=$ limite superior, $t_{112,0.975)}=2.18$

Observa-se que, para todas as variáveis, năo houve efeito significativo para o desvio da regressáo, ratificando, portanto, a suficiéncia de se fazer a comparação entre os delineamentos através do efeito linear do espaçamento. 
Com exceçăo do volume total, todas as demais variáveis tiveram efeito linear significativo do espaçamento, ou seja, os coeficientes angulares $\hat{b}_{1}$ diferiram de zero, havendo resposta destas variáveis ao espaçamento. No caso do DAP, altura e volume individual, este efeito é crescente $\left(\hat{b}_{f}>0\right)$, e para a área basal, decrescente $\left(\hat{b}_{1}<0\right)$. Nota-se ainda que os valores de $F$ para a regressáo referente ao DAP e volume individual, săo elevados, comparativamente aos da altura e área basal.

Estes comportamentos estāo coerentes com as observaçóes de resposta de crescimento individual e conjunto de árvores em espaçamentos crescentes (ASSMANN 1970; EVERT 1971; SCHENEIDER 1993). A nåo significancia de $b_{1}$ para volume total, mostra que aos 71 meses, e para espaçamentos entre 4,5 e $9,0 \mathrm{~m}^{2} /$ planta, o efeito compensatório de crescimento das árvores já possibilitou a equiparaçăo das produçoes por área.

\subsection{Delineamento Sistemático Tipo "Leque"}

O delineamento sistemático tipo 'leque" ocupou uma área de $5972 \mathrm{~m}^{2}$, sendo $1103 \mathrm{~m}^{2}$ (18\%) ocupado pelas bordaduras (Figura 9). A sobrevivéncia, de $99 \%$, foi excelente, ocorrendo apenas 5 falhas/mortes em todo o experimento

$O$ bom crescimento do E.dunnii, ao longo das 5 avaliaçóes e ros dez espaçamentos do delineamento sistemático tipo "leque", pode ser constatado rias Tabelas 22, 23, 24, 25 e 26, onde săo expostos os valores médios do DAP, altura, volume individual, área basal e volume total, respectivamente. Este desenvolvimento expressa mais uma vez o excelente potencial da espécie para regiőes edafoclimáticas semelhantes à área experimental (GOLFARI et alii, 1978; EMBRAPA, 1986).

Pela análise das Tabelas 22 a 26, observa-se um aumento dos valores médios do DAP, altura e volume sólido individual total nos espaçamento mais largos, acompanhados de uma tendéncia de diminuiçăo da área basal e volume total por hectare. 
TABELA 22. DAP médio (cm), por tratamento e idade de avaliaçăo, do E.dunnii, no delineamento sistemático tipo "leque".

\begin{tabular}{|c|c|c|c|c|c|}
\hline Tratamento & \multicolumn{5}{|c|}{ IDADE (meses) } \\
\hline (m²/planta) & $\mathbf{2 6}$ & $\mathbf{4 2}$ & $\mathbf{4 8}$ & $\mathbf{6 0}$ & $\mathbf{7 1}$ \\
\hline $1-1,40$ & 5,52 & 6,48 & 6,65 & 6,99 & 7,41 \\
\hline $2-2,05$ & 6,68 & 8,02 & 8,49 & 8,87 & 9,29 \\
\hline $3-3,01$ & 7,30 & 8,85 & 9,12 & 9,61 & 10,02 \\
\hline $4-4,41$ & 8,98 & 11,37 & 11,70 & 12,47 & 12,92 \\
\hline $5-6,47$ & 9,79 & 12,75 & 13,14 & 13,91 & 14,62 \\
\hline $6-9,50$ & 10,98 & 14,86 & 15,43 & 16,44 & 17,39 \\
\hline $7-13,93$ & 11,55 & 16,29 & 17,06 & 18,39 & 19,38 \\
\hline $8-20,43$ & 12,92 & 18,72 & 19,61 & 21,43 & 22,74 \\
\hline $9-29,97$ & 13,62 & 19,98 & 21,15 & 23,13 & 24,64 \\
\hline $10-43,95$ & 13,49 & 20,38 & 21,68 & 23,99 & 25,66 \\
\hline
\end{tabular}

TABELA 23. Altura média (m), por tratamento e idade de avaliaçăo, do E.dunnii, no delineamento sistemático tipo "leque".

\begin{tabular}{|c|c|c|c|c|c|}
\hline Tratamento & \multicolumn{5}{|c|}{ IDADE (meses) } \\
\hline (m²/planta) & $\mathbf{2 6}$ & $\mathbf{4 2}$ & $\mathbf{4 8}$ & $\mathbf{6 0}$ & $\mathbf{7 1}$ \\
\hline $1-1,40$ & 9,38 & 11,38 & 12,16 & 13,37 & 13,63 \\
$2-2,05$ & 10,19 & 13,51 & 14,43 & 15,97 & 16,62 \\
\hline $3-3,01$ & 10,62 & 13,67 & 14,82 & 16,32 & 17,04 \\
\hline $4-4,41$ & 11,24 & 15,25 & 16,55 & 19,61 & 19,87 \\
\hline $5-6,47$ & 11,10 & 15,22 & 16,94 & 19,71 & 20,46 \\
\hline $6-9,50$ & 10,91 & 15,77 & 17,38 & 20,23 & 21,34 \\
\hline $7-13,93$ & 10,47 & 15,69 & 17,44 & 20,93 & 21,82 \\
\hline $8-20,43$ & 10,18 & 15,15 & 17,46 & 20,51 & 22,18 \\
$9-29,97$ & 9,99 & 15,28 & 17,33 & 21,04 & 22,42 \\
$10-43,95$ & 9,45 & 14,35 & 16,37 & 19,96 & 21,20 \\
\hline
\end{tabular}

TABELA 24. Volume individual médio ( $\mathrm{dm}^{3} /$ árvore), por tratamento e idade de avaliaçăo, do E.dunnii, no delineamento sistemático tipo "leque".

\begin{tabular}{|c|c|c|c|c|c|}
\hline Tratamento & \multicolumn{5}{|c|}{ IDADE (meses) } \\
\hline (m) $^{2}$ /planta) & $\mathbf{2 6}$ & $\mathbf{4 2}$ & $\mathbf{4 8}$ & $\mathbf{6 0}$ & $\mathbf{7 1}$ \\
\hline $1-1,40$ & 13,56 & 24,95 & 28,50 & 33,44 & 39,21 \\
\hline $2-2,05$ & 19,86 & 38,89 & 45,70 & 52,99 & 60,38 \\
$3-3,01$ & 23,34 & 45,35 & 52,02 & 62,24 & 70,53 \\
$4-4,41$ & 35,21 & 75,13 & 85,77 & 115,51 & 122,08 \\
$5-6,47$ & 41,25 & 93,78 & 109,65 & 147,74 & 161,03 \\
\hline $6-9,50$ & 49,24 & 126,62 & 149,36 & 210,33 & 234,75 \\
\hline $7-13,93$ & 51,80 & 148,65 & 179,25 & 269,13 & 293,82 \\
\hline $8-20,43$ & 61,72 & 186,78 & 233,76 & 364,62 & 410,83 \\
\hline $9-29,97$ & 66,79 & 209,02 & 262,19 & 426,57 & 472,03 \\
\hline $10-43,95$ & 64,30 & 212,79 & 271,64 & 460,66 & 510,40 \\
\hline
\end{tabular}


TABELA 25. Área basal média ( $\mathrm{m}^{2} / \mathrm{ha}$ ), por tratamento e idade de avaliaçăo do E. dunnii, no delineamento sistemático tipo "leque".

\begin{tabular}{|c|c|c|c|c|c|}
\hline Tratamento & \multicolumn{5}{|c|}{ IDADE (meses) } \\
\hline (m/2/planta) & $\mathbf{2 6}$ & $\mathbf{4 2}$ & $\mathbf{4 8}$ & $\mathbf{6 0}$ & $\mathbf{7 1}$ \\
\hline $1-1,40$ & 18,90 & $\mathbf{2 7}, 46$ & 29,26 & $\mathbf{3 2}, 99$ & $\mathbf{3 7}, 51$ \\
\hline $2-2,05$ & 18,27 & 27,13 & 30,21 & 33,23 & 36,49 \\
\hline $3-3,01$ & 14,60 & 21,91 & 23,32 & 26,15 & 28,69 \\
\hline $4-4,41$ & 14,76 & 23,77 & 25,21 & 28,74 & 30,95 \\
\hline $5-6,47$ & 12,01 & 20,49 & 21,78 & 24,53 & 27,08 \\
\hline $6-9,50$ & 10,18 & 18,71 & 20,23 & 23,13 & 25,93 \\
\hline $7-13,93$ & 7,66 & 15,26 & 16,77 & 19,54 & 21,80 \\
\hline $8-20,43$ & 6,48 & 13,67 & 15,03 & 18,05 & 20,33 \\
\hline $9-29,97$ & 4,91 & 10,55 & 11,83 & 14,18 & 16,10 \\
\hline $10-43,95$ & 3,33 & 7,60 & 8,62 & 10,59 & 12,13 \\
\hline
\end{tabular}

TABELA 26. Volume total médio $\left(\mathrm{m}^{3} / \mathrm{ha}\right)$, por tratamento e idade de avaliaçăo do E.dunnii, no delineamento sistemático tipo "leque".

\begin{tabular}{|c|c|c|c|c|c|}
\hline Tratamento & \multicolumn{5}{|c|}{ IDADE (meses) } \\
\hline (m²/planta) & 26 & 42 & 48 & 60 & 71 \\
\hline $1-1,40$ & 96,89 & 178,21 & 203,56 & $\overline{238}, \overline{89}$ & 280,09 \\
\hline $2-2,05$ & 96,86 & 189,70 & 222,92 & 258,51 & $2 \overline{94,54}$ \\
\hline $3-3,01$ & 77,54 & 150,68 & 172,81 & 20678 & 234,32 \\
\hline 4,41 & 79,85 & 170,37 & 194,50 & 261,93 & 276,83 \\
\hline $5-6,47$ & 63,76 & 144,95 & 169,47 & 228,35 & 248.89 \\
\hline $6-9,50$ & 51,83 & 133,28 & $\cdot 157,22$ & 221,40 & 247,11 \\
\hline$\overline{7}-1 \overline{3}, \overline{3}$ & 37,19 & 106,72 & 128,68 & $193, \overline{2}$ & 210,93 \\
\hline 8. 20,43 & 30,21 & 91,43 & 114,42 & 178,47 & 201,09 \\
\hline 9. 29,97 & 22,29 & 69,74 & 87,48 & 142,33 & 157,50 \\
\hline $10-43,95$ & 14,63 & 48,42 & 61,81 & 104,81 & 116,13 \\
\hline
\end{tabular}

Evidencia-se, portanto, que o delineamento sistemático tipo "leque" criou gradientes de espaçamento capazes de influenciar as variáveis dendrométricas em estudo, confirmando as potencialidades de uso deste delineamento no estudos de espaçamentos florestais (NAMKOONG 1967; TENNENT 1975; WRIGHT 1976; LAND \& NANCE 1987)

Face a esta constataçăo, vê-se a necessidade de confrontar estes resultados com os obtidos no delineamento em blocos casualizados, efetuado através das Figuras $11,12,13,14$ e 15. 


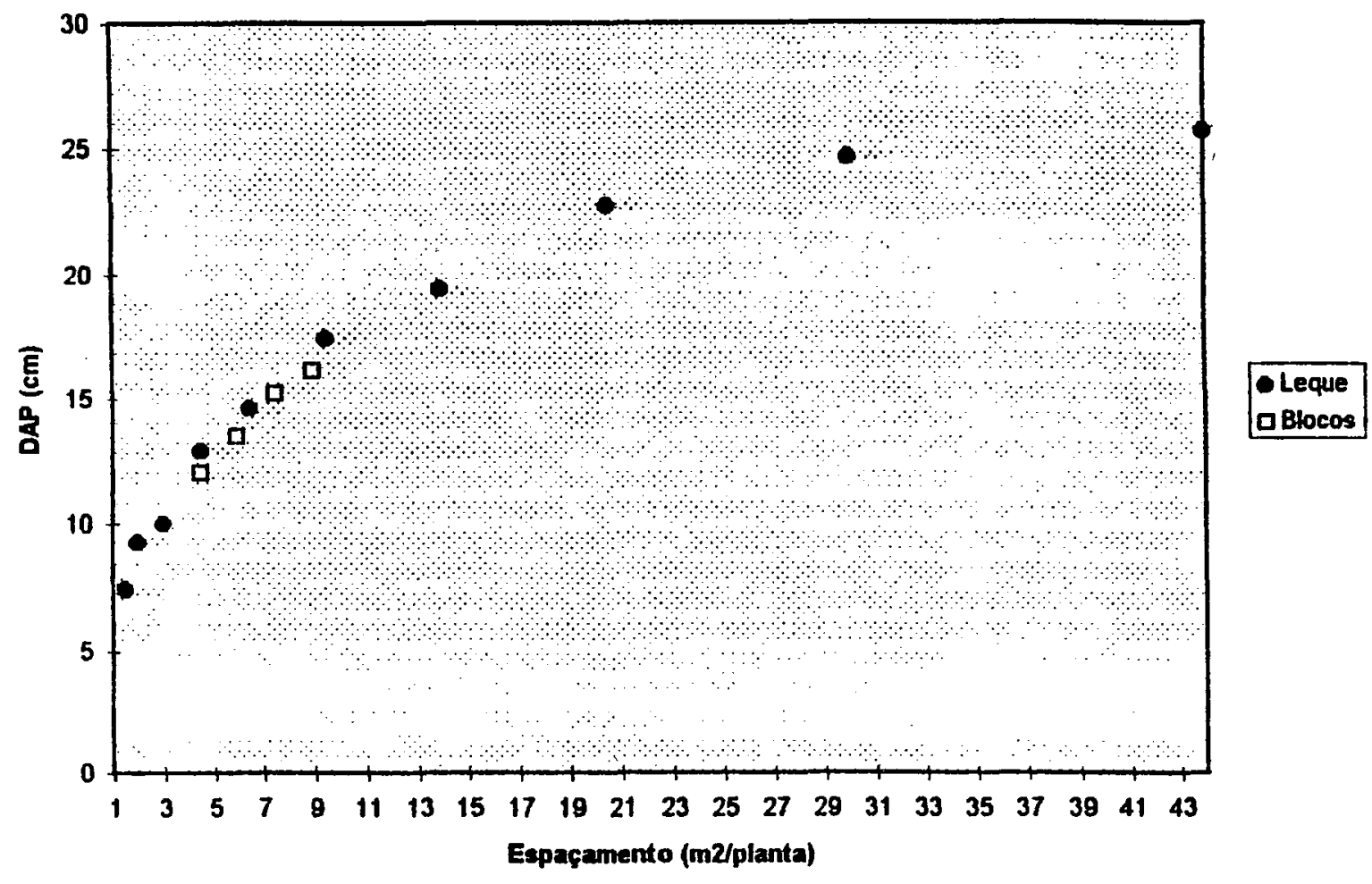

FIGURA 11. DAP médio (cm) do E.dunnii, aos 71 meses, nos diferentes espaçamentos, para o delineamento em blocos casualizados e sistemático tipo "leque".

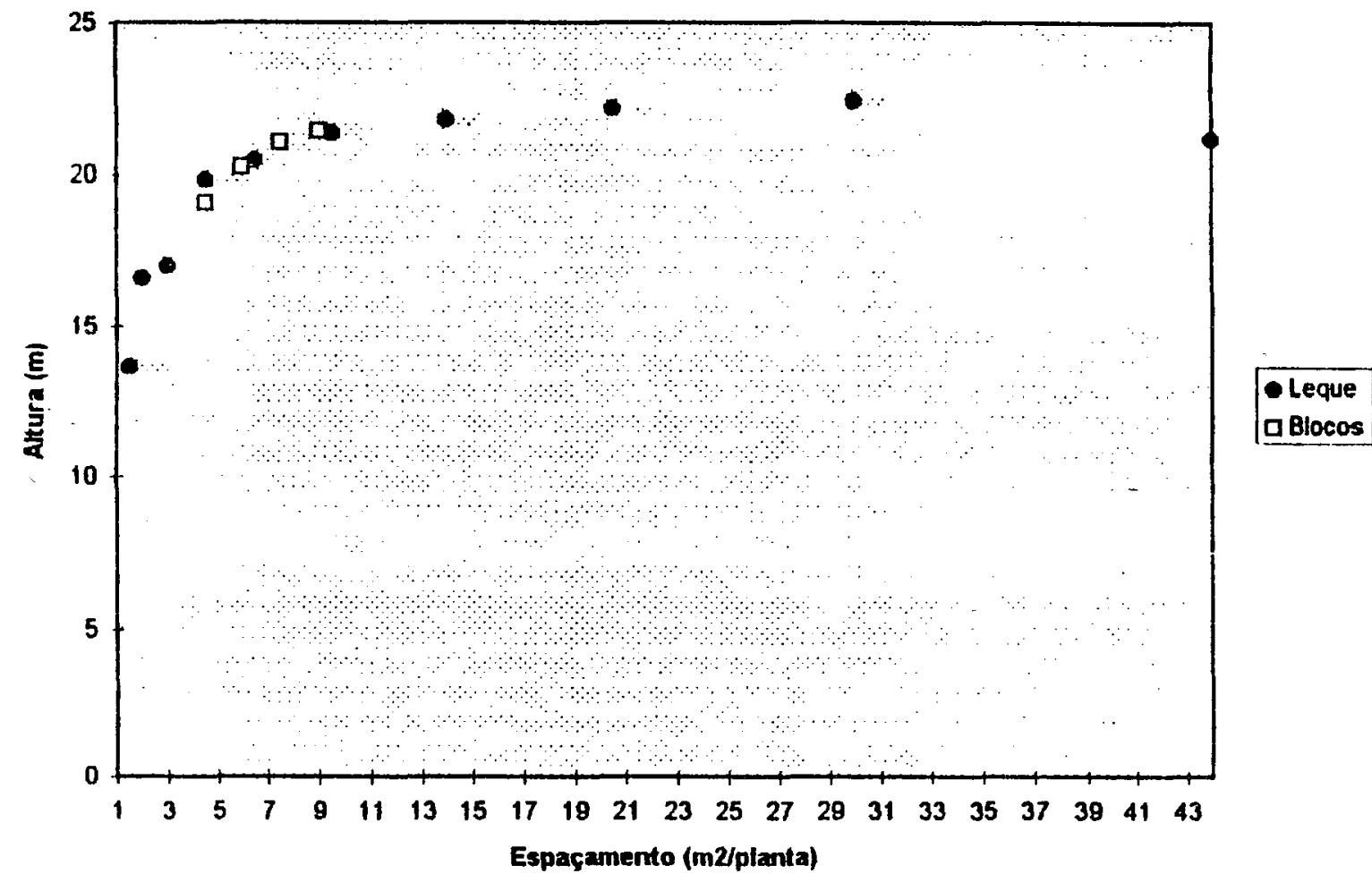

FIGURA 12. Altura média (m) do E.dunnii, aos 71 meses, nos diferentes espaçamentos, para o delineamento em blocos casualizados e sistemático tipo "leque". 


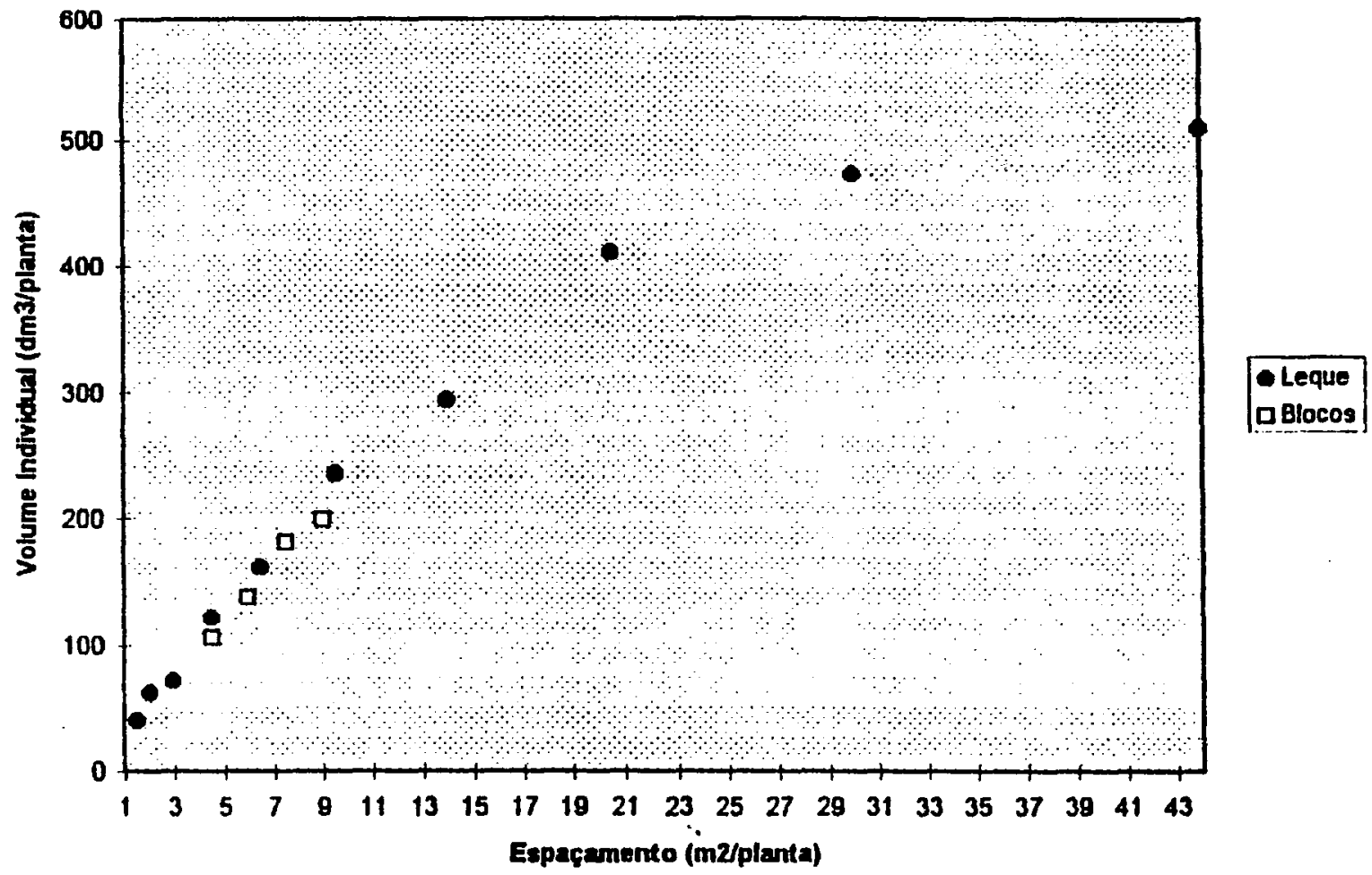

FIGURA 13. Volume individual médio (dm³/planta) do E.dunnii, aos 71 meses, nos diferentes espaçamentos, para o delineamento em blocos casualizados e sistemático tipo "leque".

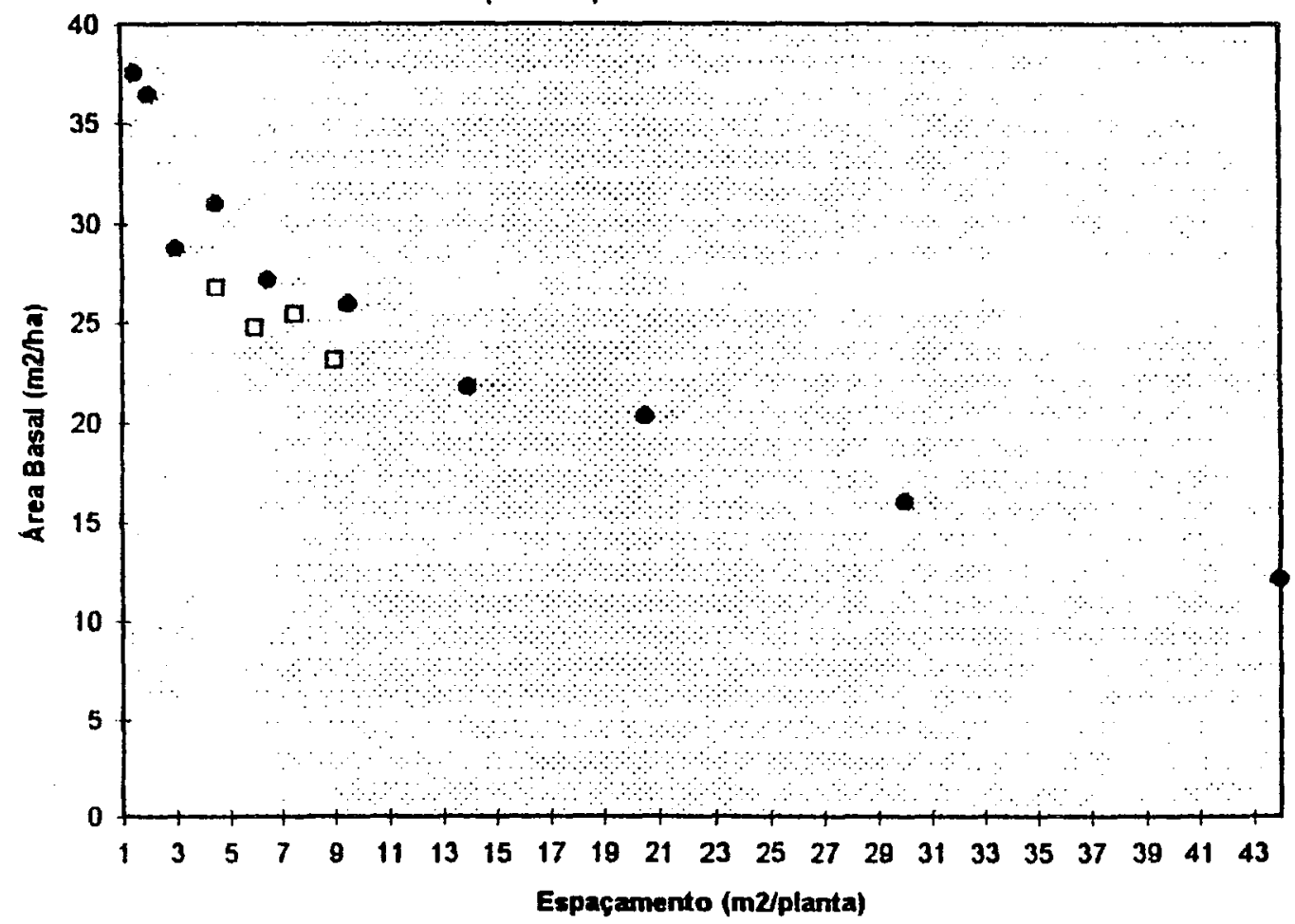

FIGURA 14 Área basal média $\left(\mathrm{m}^{2} / \mathrm{ha}\right)$ do E.dunnii, aos 71 meses, nos diferentes espaçamentos, para o delineamento em blocos casualizados e sistemático tipo "leque". 


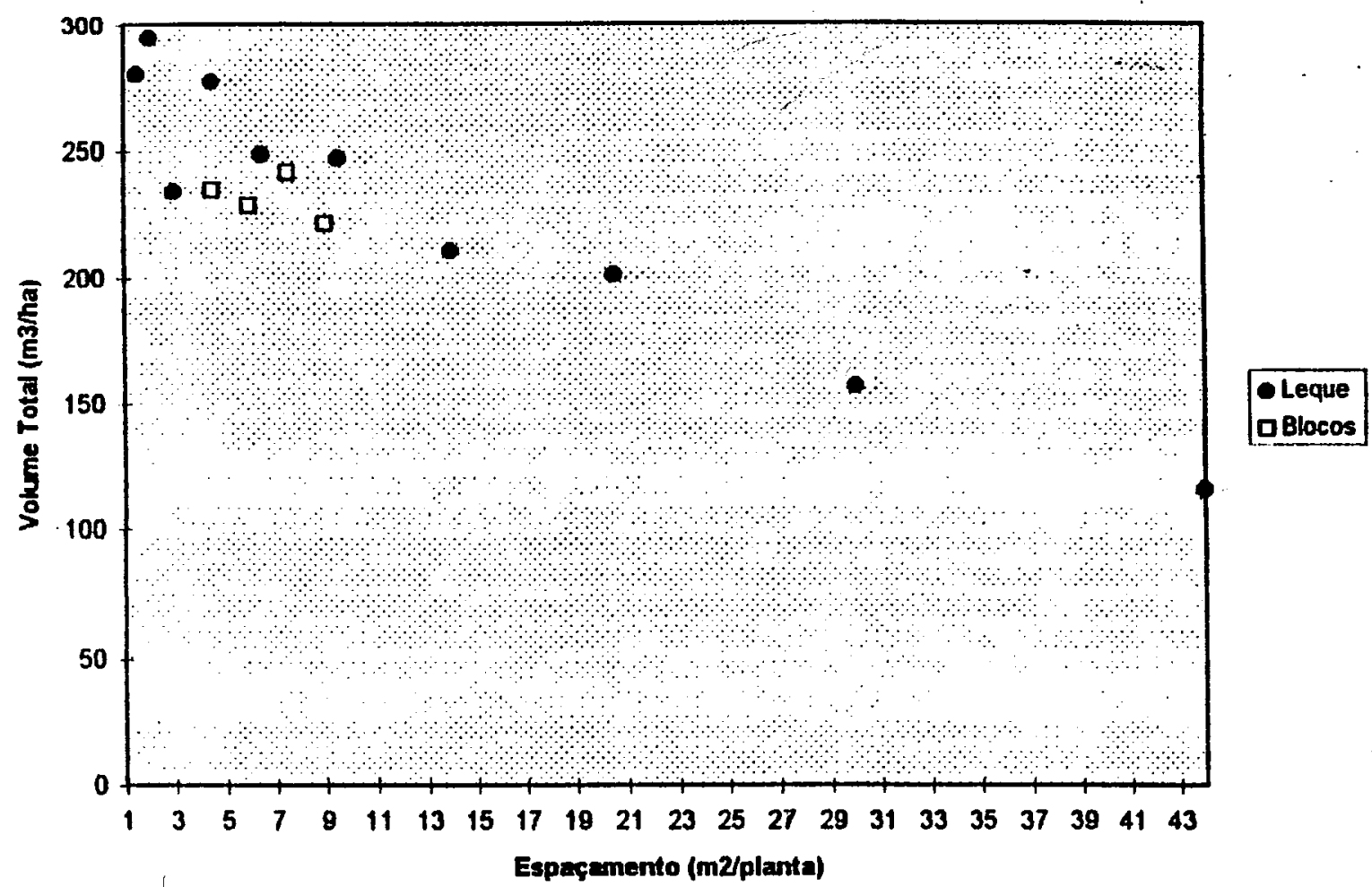

FIGURA 15. Volume total médio ( $\mathrm{m}^{3} / \mathrm{ha}$ ) do E.dunnii, aos 71 meses, nos diferentes espaçamentos, para o delineamento em blocos casualizados e sistemático tipo "leque".

Analisando-se os gráficos das Figuras 11 a 15, e observando a faixa de espaçamentos similares, entre 4 a $9,5 \mathrm{~m}^{2} /$ planta, verifica-se que há uma tendéncia de comportamento semelhante do E.dunnii frente ao espaçamento nos dois delineamentos, para todas as 5 variáveis em estudo. No entanto, apenas para a altura (Figura 12) as médias dos delineamentos se aproximam bastante, enquanto para o DAP, volume individual, área basal e volume total (Figuras 11, 13, 14 e 15, respectivamente), as médias do delineamento sistemático săo sempre superiores às do delineamento em blocos casualizados.

MINAMI (1977), estudando a produçăo de beringelas em delineamentos em blocos casualizados e sistemático tipo "leque" também encontrou superioridade para o delineamento sistemático no tocante à produçăo por área, mas năo creditou-a à diferença de arranjo das plantas nesses delineamentos.

No entanto, NELDER (1962), BLEASDALE (1966) e NAMKOONG (1967) já preconizavam valores de incremento de raio nos tratamentos sistemáticos tipo "leque" inferiores a $10 \%(\alpha<1,111)$, evitando-se com isso criarem-se gradientes 
muito acentuados de aumento de área, que interfeririam no efeito compensatório dos tratamentos anterior e posterior.

Assim, o valor de incremento de área utilizado no presente estudo $(\alpha=$ 1,21), pode ser um dos fatores que está contribuindo para este aparente comportamento diferenciado do delineamento sistemático tipo "leque" e em blocos casualizados, para áreas individuais por planta similares (MEAD, 1988).

Pode-se inferir, para o presente delineamento sistemático tipo "leque", que o seu arranjo de plantio está propiciando maior disponibilidade dos fatores produtivos, como luz, água e nutrientes, às plantas, sob um determinado espaçamento, do que o delineamento em blocos casualizados. MONTEIRO \& CORDEIRO (1983) também obtiveram maiores dimensóes das árvores de E.dunnii quando plantadas em arboreto, comparativamente ao plantio em blocos casualizados, para um mesmo espaçamento.

Como o delineamento em blocos casualizados é tomado como padrăo do comportamento da espécie em condiçóes de maciço florestal, a existéncia de um desvio nas respostas das variáveis dendrométricas quando do uso do delineamento sistemático tipo "leque" impossibilitaria a utilizaçăo direta dos valores obtidos neste delineamento para tomadas de decisóes relativas aos espaçamentos dos plantios comerciais (PEARCE, 1989; RAO et alii, 1990). Assim, fez-se necessário avaliar cuidadosamente o comportamento diferenciado das variáveis nos experimentos, para espaçamentos semelhantes.

Em virtude da impossibilidade de análise de variancia do experimento sistemático tipo "leque" (SCOTT, 1962; MEAD, 1988; PEARCE 1989) optou-se pela visualização gráfica do comportamento das 5 variáveis em estudo, nas 5 repetições do experimento como sugerem CLEAVER et alii (1978) e BAUDER et alii (1978).

As Figura 16, 17, 18, 19 e 20 apresentam, respectivamente, os valores do DAP, altura, volume individual, área basal e volume total, aos 71 meses, para as 5 repetiçőes do delineamento sistemático tipo "leque". 


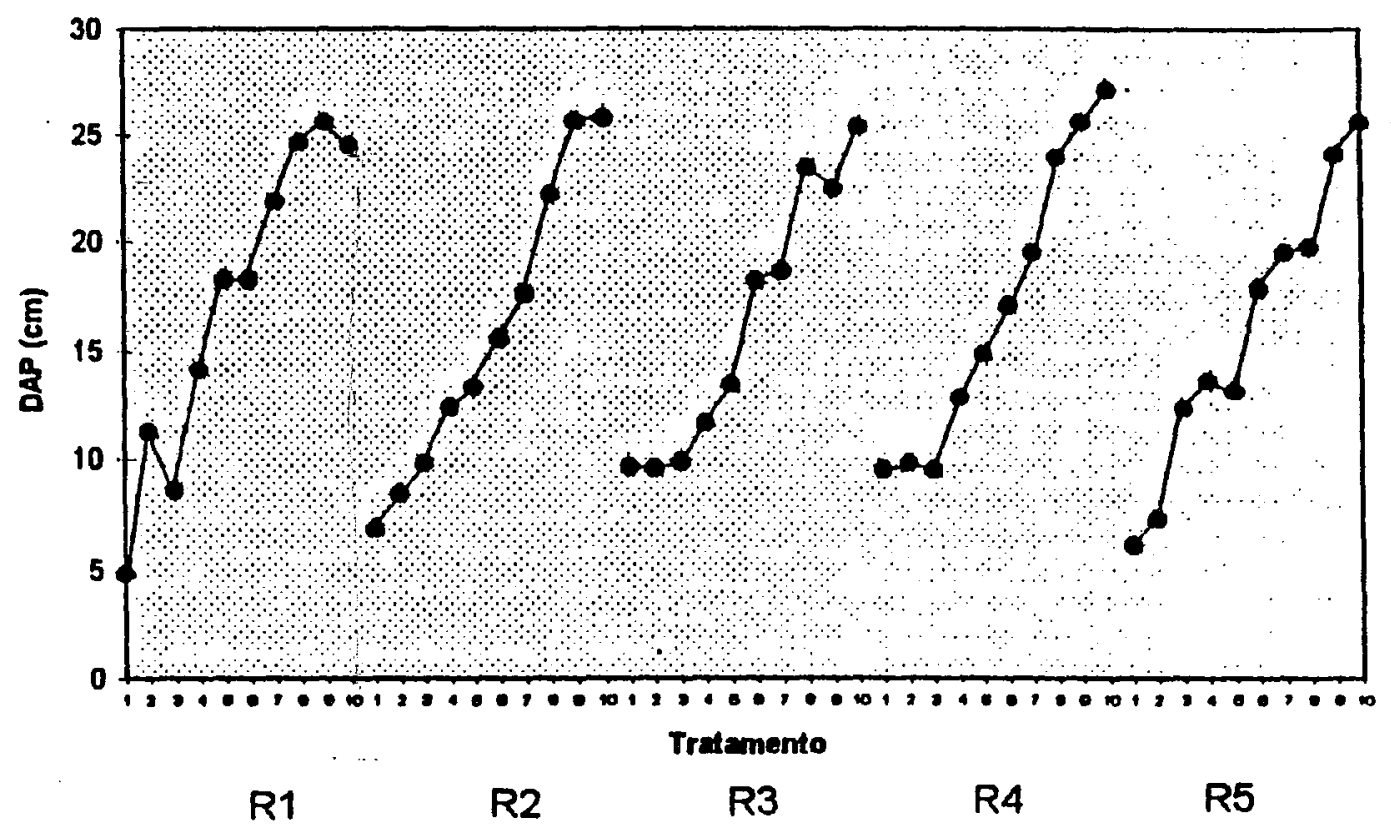

FIGURA 16. DAP médio $(\mathrm{cm})$, dos tratamentos 1 a 10 , para as 5 repetiçoes do delineamento sistemático tipo "leque".

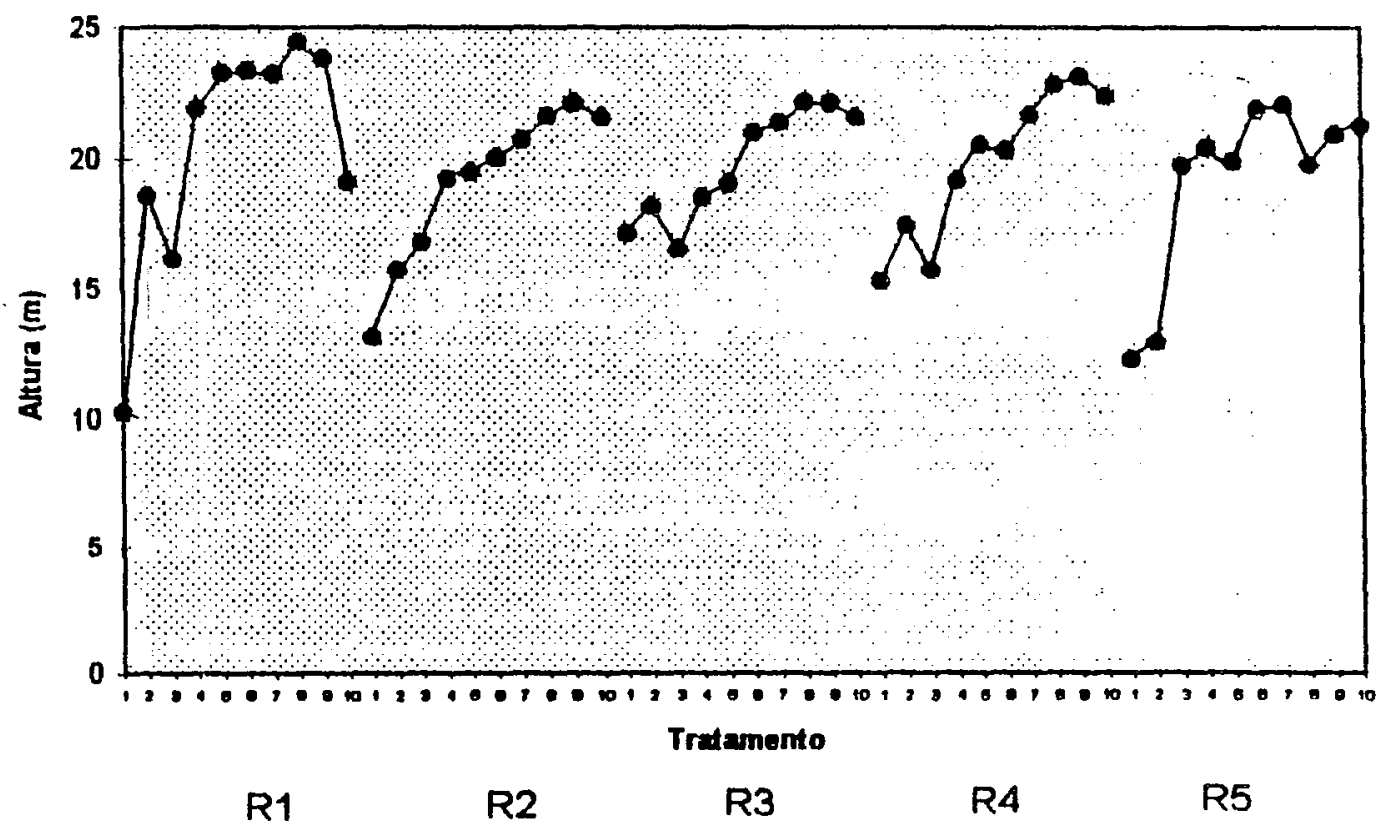

FIGURA 17. Altura média $(\mathrm{m})$, dos tratamentos 1 a 10 , para as 5 repetiçoes do delineamento sistemático tipo "leque". 


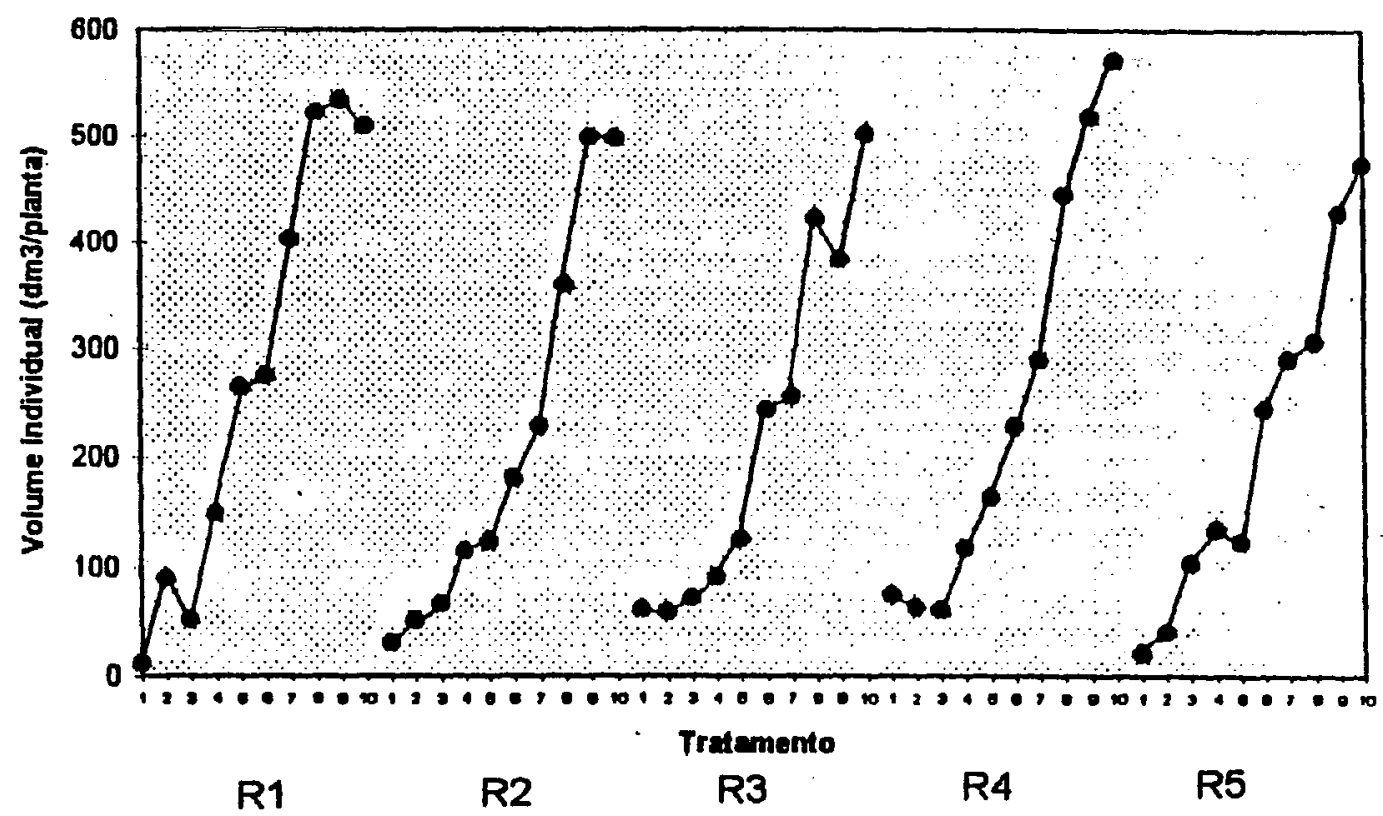

FIGURA 18. Volume individual médio ( $\mathrm{dm}^{3} /$ planta), dos tratamentos 1 a 10 , para as 5 repetiçóes do delineamento sistemático tipo "leque".

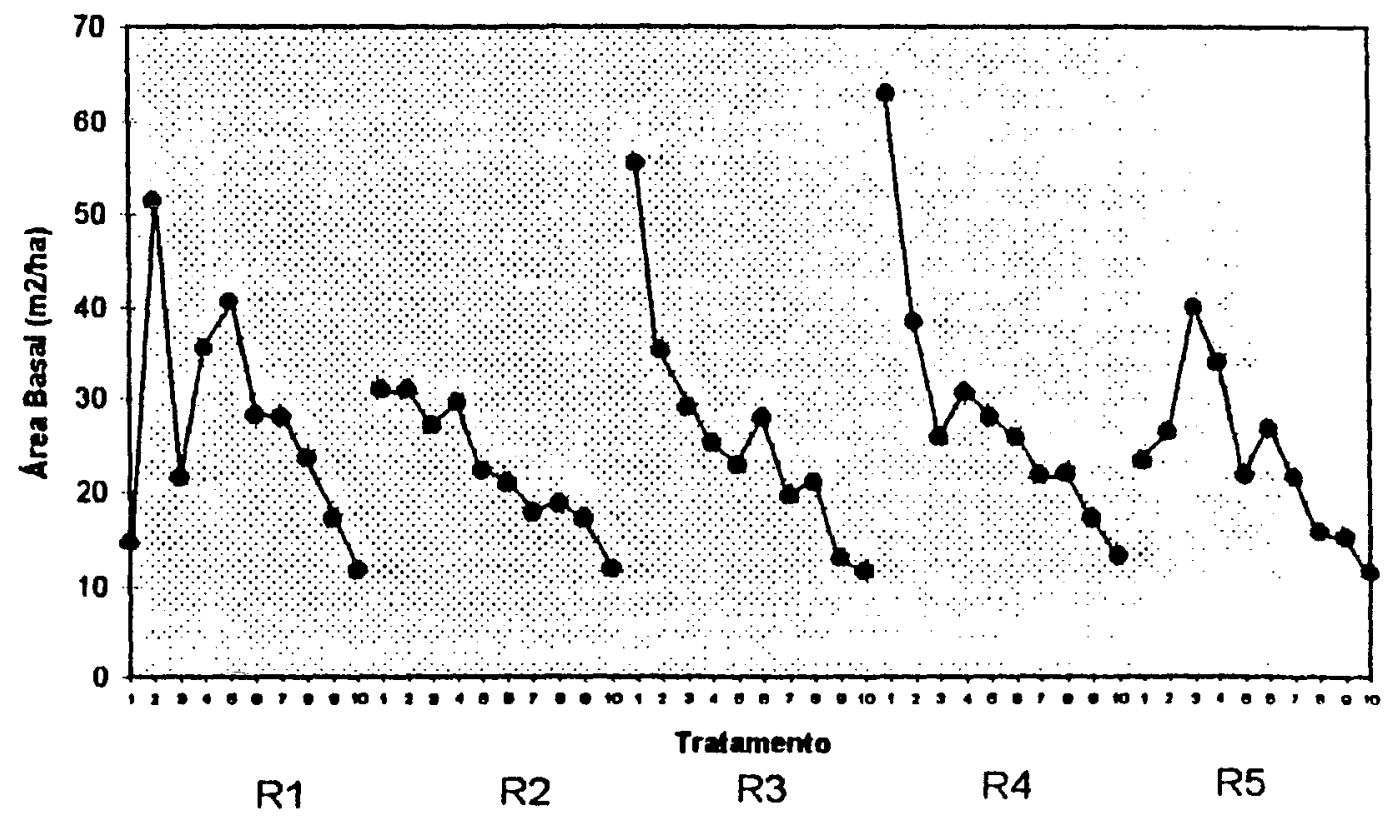

FIGURA 19. Área basal $\left(\mathrm{m}^{2} / \mathrm{ha}\right)$, dos tratamentos 1 a 10 , para as 5 repetiçס̃es do delineamento sistemático tipo "leque". 


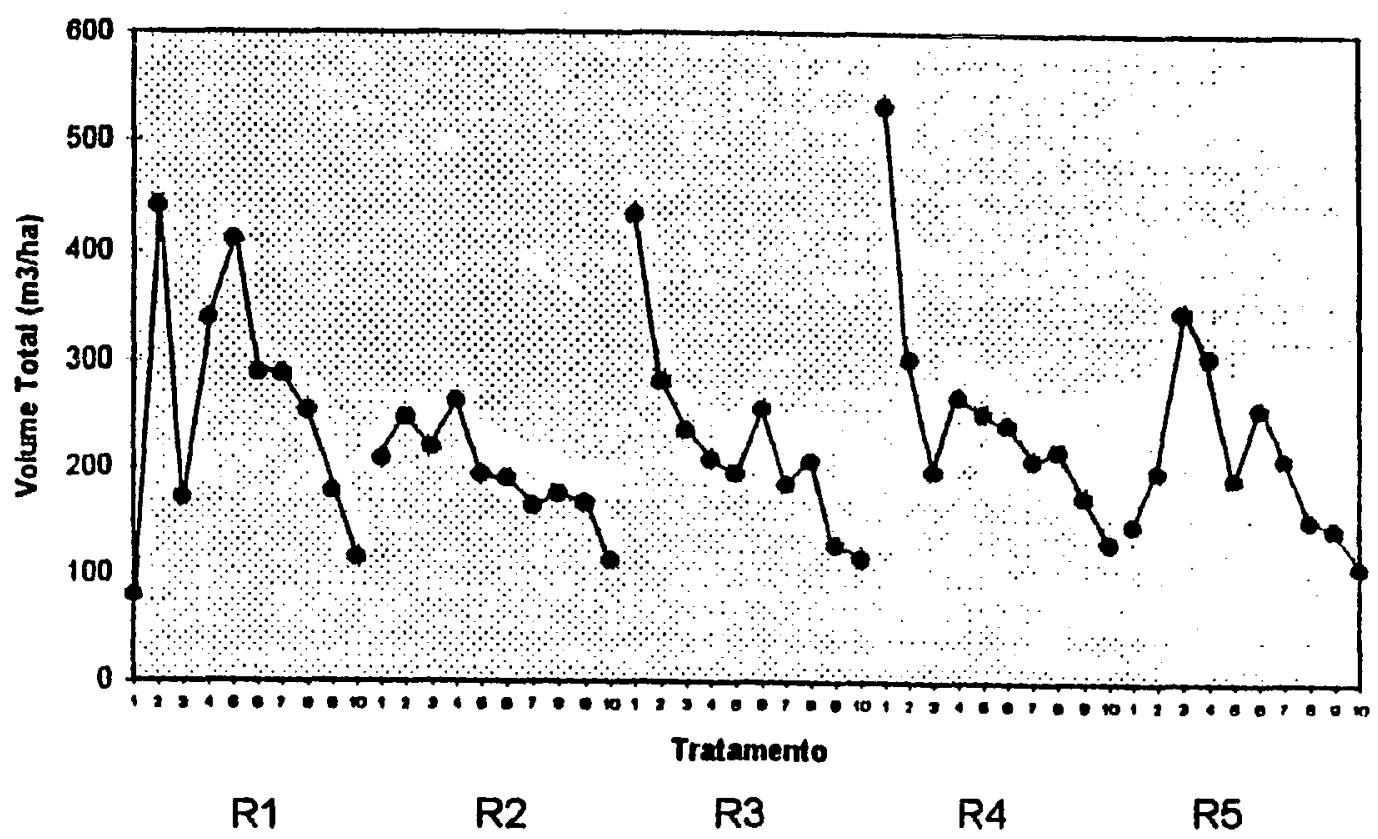

FIGURA 20. Volume total $\left(\mathrm{m}^{3} / \mathrm{ha}\right)$, dos tratamentos 1 a 10 , para as 5 repetiçoes do delineamento sistemático tipo "leque".

Constata-se que para as caracteristicas individuais das plantas, como DAP, altura e volume individual (Figuras 16,17 e 18, respectivamente), o comportamento frente ao espaçamento foi semelhante entre as repetiçóes. No entanto, para a área basal (Figura 19) e volume total (Figura 20) observam-se divergéncias de comportamento, notadamente no tratamento 1 , ora com altos valores, ora com baixos valores, comparativamente aos demais.

Com o objetivo de quantificar esta variaçăo elaborou-se a Tabela 27 onde constam as variâncias, por tratamento, para as 5 variáveis em estudo, e a razáo entre a maior e menor variancia, com e sem a participaçăo do tratamento 1,0 qual possui as maiores variáncias para área basal e volume total.

Nota-se que a variancia do tratamento 1, para as variáveis que expressam valores por hectare, destoa completamente das demais, creditando-se isso a pequena área da parcela, e consequentemente ao grande valor do fator de expansăo por hectare $(k=1190)$ (BAUDER et alii, 1975; LIN \& MORSE 1975). Além disso, o fato de ser sempre o tratamento 1 o mais próximo à bordadura interna deve acarretar maiores interferéncias do centro do circulo (Figura 9), ao criar um microclima 
diferenciado (PEARCE 1989), influenciando no comportamento das plantas (HUXLEY, 1985).

TABELA 27. Variância, por tratamento, para as 5 variáveis em estudo, aos 71 meses, no delineamento sistemático tipo "leque", e razáo entre a maior $(M x)$ e menor (Mi) variancias, com e sem a participaçăa do tratamento 1.

\begin{tabular}{|c|c|c|c|c|c|c|}
\hline TRAT. & ESP(m ${ }^{2}$ (p) & DAP & ALTURA & V.IND. & A.BASAL & V.TOTAL \\
\hline 1 & 1,40 & 4,52 & 7,29 & 731,44 & 433,25 & 37318,09 \\
\hline 2 & 2,05 & 2,13 & 5,43 & 342,66 & 89,64 & 8153,67 \\
\hline 3 & 3,01 & 1,93 & 2,47 & 402,87 & 46,78 & 4446,71 \\
\hline 4 & 4,41 & 0,93 & 1,77 & 466,24 & 16,13 & 2397,36 \\
\hline 5 & 6,47 & 4,47 & 2,78 & 3683,19 & 62,01 & 8798,68 \\
\hline 6 & 9,50 & 1,13 & 1,84 & 1207,63 & 8,40 & 1338,10 \\
\hline 7 & 13,93 & 2,35 & 0,86 & 4298,97 & 14,12 & 2215,45 \\
\hline 8 & 20,43 & 3,67 & 2,91 & 6697,24 & 9,18 & 1604,56 \\
\hline 9 & 29,97 & 2,03 & 1,20 & 4191,96 & 3,13 & 466,70 \\
\hline 10 & 43,95 & 0,93 & 1,48 & 1356,62 & 0,45 & 70,23 \\
\hline Mx/Mi 1 a 10 & & 4,86 & 8,47 & 19,54 & 962,78 & 531,37 \\
\hline Mx/Mi 2 a10 & & - & - & - & 199,20 & 116,09 \\
\hline
\end{tabular}

Optou-se entăo pela eliminaçăo do tratamento 1, quando do ajuste de equaçøes de resposta ao espaçamento (item 4.3.2) no delineamento sistemático tipo "leque", para as variáveis área basal e volume total. A alternativa de utilizaçăo da regressăo linear ponderada para estas 2 variáveis, face a heterocedasticia, bem como a análise de residuos, năo foi implementada pelo fato do trabalho ser uma primeira abordagem no tocante à viabilidade de utilizaçăo do delineamento tipo "Leque",

\subsubsection{Análise de Regressăo Linear}

Objetivando-se comparar os resultados de ambos delineamentos, numa faixa semelhantı de espaçamento, efetuaram-se as análises de regressăo linear para as 5 variáveis em estudo, conforme a Tabela 13, utilizando-se apenas dos valores obtidos nos tratamentos 4,5 e $6\left(4,41\right.$ a $9,50 \mathrm{~m}^{2} /$ planta).

A Tabela 28 apresenta o quadrado médio do resíduo, o valor do teste $F$ para a regressão, e as estimativas dos parámetros $b_{0}$ e $b_{1}$, e seus respectivos 
intervalos de confiança para $95 \%$ de probabilidade, para as 5 variáveis em estudo, aos 71 meses.

TABELA 28. Quadrado médio do resíduo (QMR), teste $F$ para regressāo, estimativas dos parametros $b_{0}$ e $b_{1}$ da regressăo linear, e seus intervalos de confiança para $95 \%$ de probabilidade, das 5 variáveis em estudo, no delineamento sistemático tipo "leque".

\begin{tabular}{|c|c|c|c|c|c|c|}
\hline Valor & (1) & DAP & ALTURA & V.IND. & A.BASAL & V.TOTAL \\
\hline & & (cm) & (m) & $\left(\mathrm{dm}^{3} / \mathrm{pl}\right)$ & $\left(m^{2} / h a\right)$ & $\left(m^{3} / h a\right)$ \\
\hline QMR & $(13 \mathrm{gl})$ & 2,016 & 1,969 & 1659,530 & 27,499 & 3920,792 \\
\hline $\mathrm{F}$ & & $25,23^{\star *}$ & $2,81 \mathrm{~ns}$ & $19,64^{\star \star}$ & $2,10^{\mathrm{ns}}$ & $0,50 \mathrm{~ns}$ \\
\hline$b_{0}$ & $\begin{array}{l}\text { li } \\
\text { es } \\
\text { is }\end{array}$ & $\begin{array}{c}6,300 \\
8,992 \\
11,685\end{array}$ & $\begin{array}{l}15,920 \\
18,581 \\
21,242\end{array}$ & $\begin{array}{c}-56,112 \\
21,133 \\
98,379\end{array}$ & $\begin{array}{l}24,429 \\
34,372 \\
44,316\end{array}$ & $\begin{array}{l}175,880 \\
294,613 \\
413,346\end{array}$ \\
\hline$b_{1}$ & $\begin{array}{l}\text { li } \\
\text { es } \\
\text { is }\end{array}$ & $\begin{array}{l}0,502 \\
0,881 \\
1,260\end{array}$ & $\begin{array}{l}-0,084 \\
0,290 \\
0,665\end{array}$ & $\begin{array}{l}11,431 \\
22,299 \\
33,167\end{array}$ & $\begin{array}{l}-2,339 \\
-0,940 \\
0,459\end{array}$ & $\begin{array}{r}-22,152 \\
-5,447 \\
11,258\end{array}$ \\
\hline
\end{tabular}

(1) $\mid \mathrm{i}=$ limite inferior, es = valor estimado, $k=$ limite superior, $t_{(13,0.975)}=2: 16$.

Observa-se que apenas o DAP e volume individual apresentaram efeito linear significativo do espaçamento. Os valores de $F$ para as variáveis altura e área basal, apesar de năo significativos, săo nitidamente superiores ao do volume total, evidenciando uma leve tendéncia de apresentar coeficiente angulares $b_{1}$ significativos, provavelmente nâo o sendo dado o pequeno número de tratamentos em teste e principalmente à variância residual elevada (Tabela 28 ), comparativamente à variância observada no delineamento em blocos casualizados (Tabela 20). Para DAP e volume individual os coeficientes $b_{1}$ apresentam valores positivos, assim como a altura. Por sua vez, a área basal e volume total possuem estimativas negativas de $b_{1}$ embora estas sejam nåo significativas.

Novamente, os comportamentos das variáveis em estudo săo concordantes com os resultados experimentais de respostas individuais e conjunta das árvores ao espaçamento (ASSMANN, 1970; EVERT, 1971; LAND \& NANCE, 1987) 


\subsection{Análise Comparativa dos Delineamentos}

\subsubsection{Regressăo Linear para Faixa Similar de Espaçamentos}

Ao comparem-se as análises de regressăo linear efetuadas para os experimentos em blocos casualizados (Tabela 21) e sistemático tipo "leque" (Tabela 28), numa faixa similar de espaçamentos, constata-se semelhanças marcantes entre as mesmas.

As Figuras $21,22,23,24$ e 25 ilustram os valores médios das variáveis DAP, altura, volume individual, área basal e volume total, respectivamente, e suas regressóes lineares, para o experimento em blocos casualizados e sistemático tipo "leque", na faixa similar de espaçamento (4,4 a 9,5 $\mathrm{m}^{2} /$ planta).

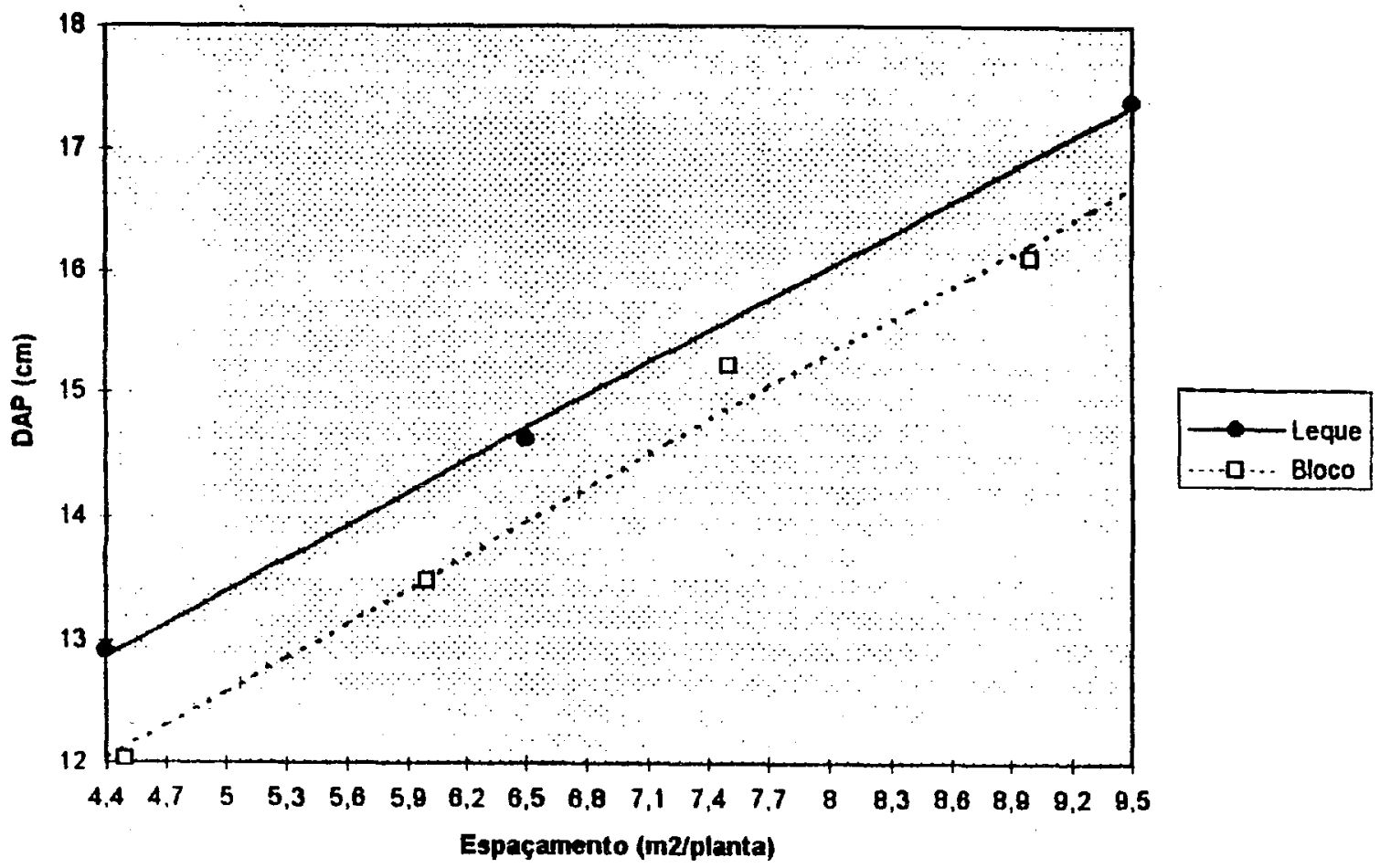

FIGURA 21. DAP médio $(\mathrm{cm})$ e regressão linear para os experimentos em blocos casualizados e sistemático tipo "leque", na faixa similar de espaçamento. 


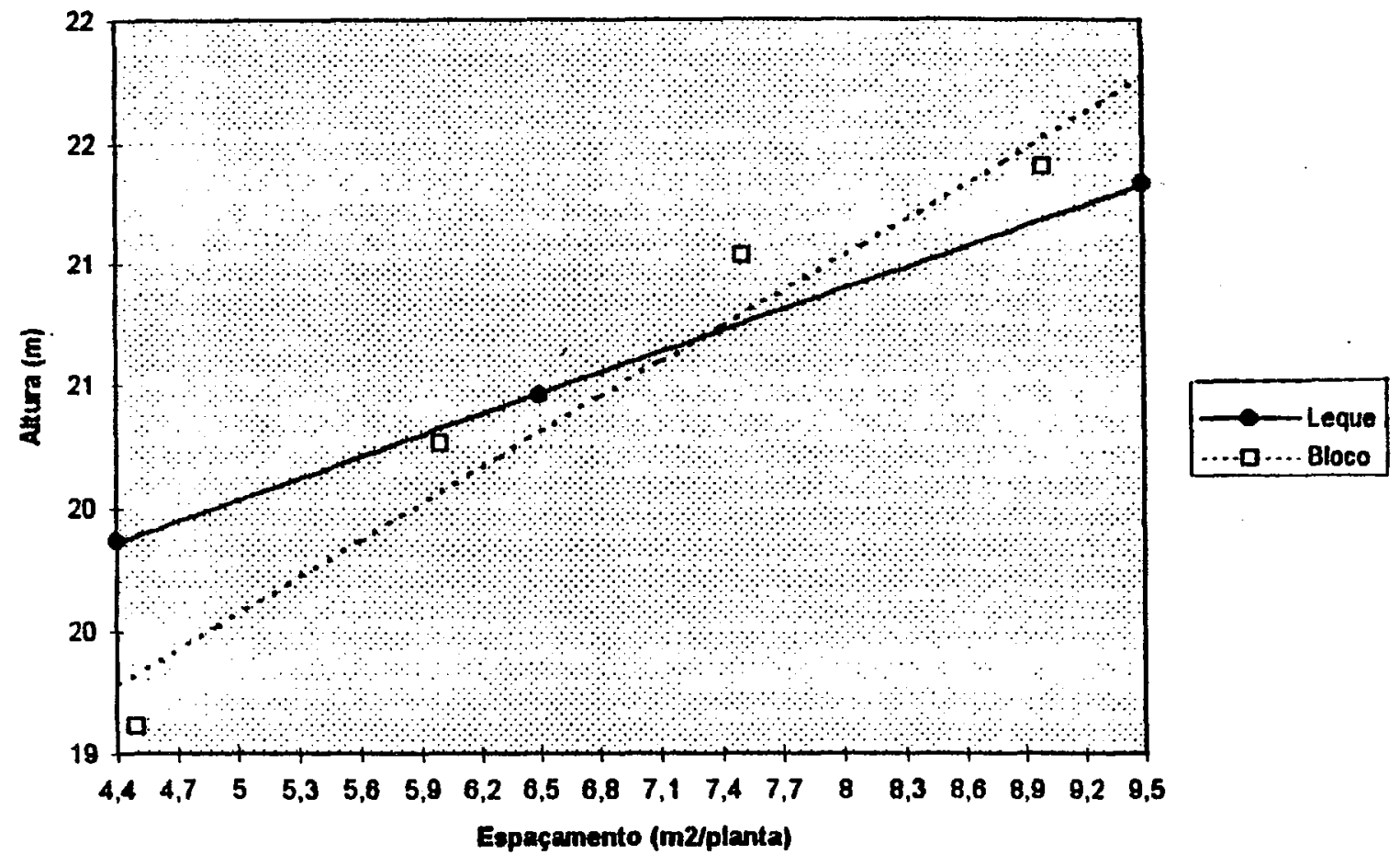

FIGURA 22. Altura média $(m)$ e regressão linear para os experimentos em blocos casualizados e sistemático tipo "leque", na faixa similar de espaçamento.

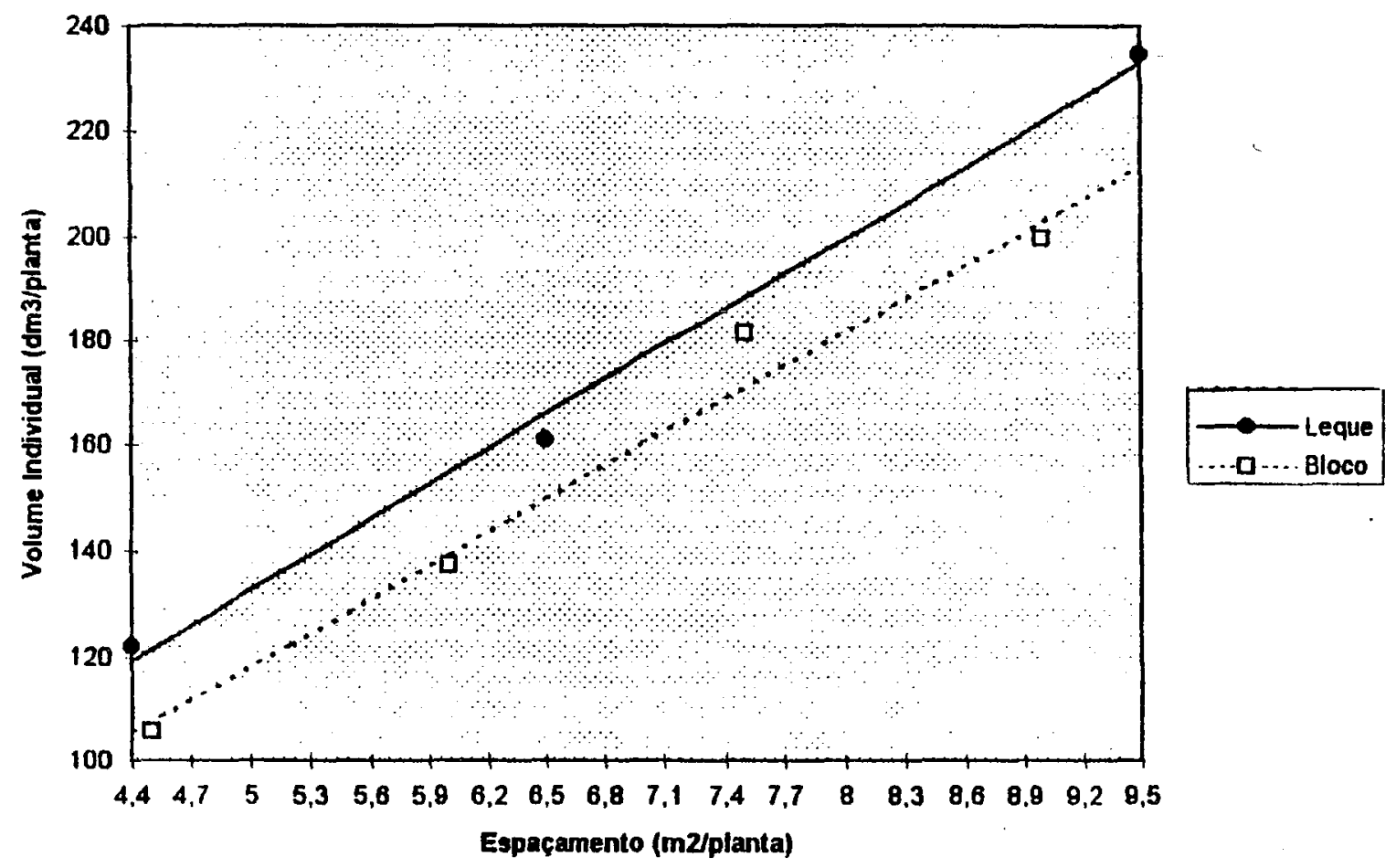

FIGURA 23. Volume individual médio ( $\mathrm{dm}^{3} /$ planta) e regressăo linear para os experimentos em blocos casualizados e sistemático tipo "leque", na faixa similar de espaçamento. 


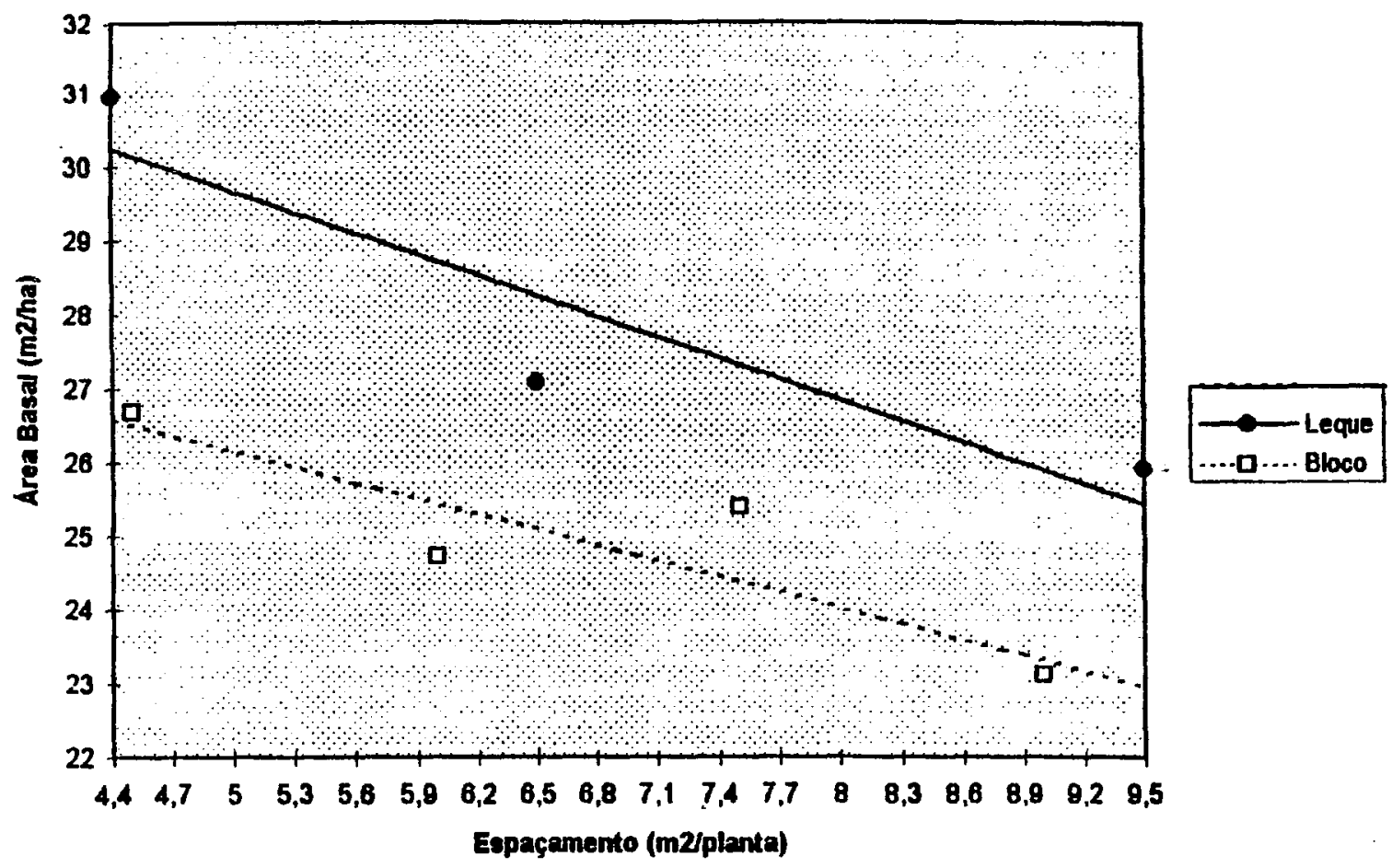

FIGURA 24. Área basal média ( $\mathrm{m}^{2} / \mathrm{ha}$ ) e regressáo linear para os experimentos em blocos casualizados e sistemático tipo "leque", na faixa similar de espaçamento.

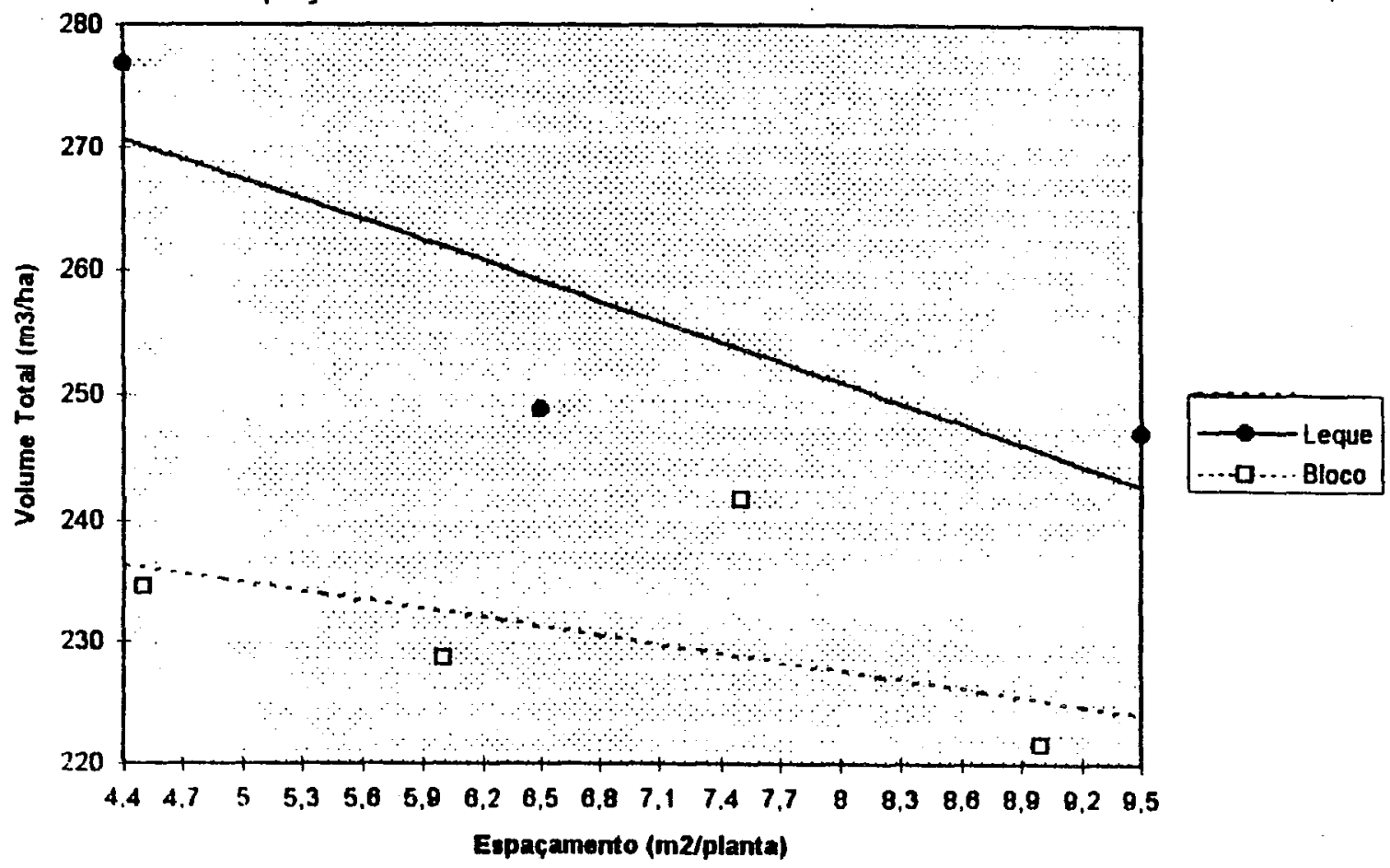

FIGURA 25. Volume total médio $\left(\mathrm{m}^{3} / \mathrm{ha}\right.$ ) e regressåo linear para os experimentos em blocos casualizados e sistemático tipo "leque", na faixa similar de espaçamento. 
Assim, para os dois delineamentos houve efeito linear significativo do espaçamento em relaçăo ao DAP e ao volume individual, e năo houve em relaçăo ao volume total.

Por outro lado, o efeito linear foi significativo no tocante à altura e área basal no delineamento em blocos casualizados năo o sendo para o delineamento sistemático tipo "leque". Este fato, no entanto, provavelmente se justifica pelo pequeno número de tratamentos (3) no delineamento sistemático, comparativamente ao delineamento em blocos casualizados (4), para a faixa comum de análise, e suas maiores variáncias residuais devido ao seu menor número de plantas por parcela, 6 , em relaçăo ao delineamento em blocos casualizados, com 25 (BAUDER et alii 1975). Assim consultando as Tabelas 20 e 28 notamos que as variancias residuais do delineamento sistemático tipo "leque" săo 9, 5, 7, 13 e 10 vezes maiores que aquelas obtidas no delineamento em blocos casualizados, respectivamente para as variáveis DAP, altura, volume individual, área basal e volume total.

Como a área experimental é homogénea, como visto no item 41 , recai entâo sobre o material genético a maior contribuiçăo sobre a variáncia residual. confirmando as afirmaçōes de Chacko (1966), citado por EVERT (1971), e MEAD (1988). Como as plantas utilizadas no ensaio såo originadas de sementes colhidas em populaçőes sem nenhum nivel de melhoramento (item 3.1.2), percebe-se claramente sua influéncia sobre o comportamento das parcelas. Assim, a utilizaçăo de mudas de espécies com maior nível de melhoramento genético ou a utilizaçăo de plantas de um mesmo clone, produzidas assexuadamente, contribuiriam sobremaneira para a reduçăo da variáncia residual e aumentando, consequentemente, a sensibilidade do teste $\mathrm{F}$ e a redução dos intervaios de confiança das estimativas dos parâmetros $b_{0}$ e $b_{1}$.

Face ao exposto, nota-se, por exemplo, uma estratificaçăo nos valores do teste $F$ da regressăo no delineamento em blocos casualizados que é idéntico a estratificaçáo observada no sistemático tipo "leque", ou seja, F efeito linear ( DAP, volume individual) $>F$ efeito linear (altura, área basal) $>F$ efeito linear (volume total) 
As Figuras 26 e 27 também auxiliam na comparaçăo do comportamento das 5 variáveis em estudo, nos dois delineamentos, ao apresentarem os intervalos de confiança para os parametros $b_{0}$ e $b_{1}$ das regressóes lineares comparativamente aos parâmetros $b_{0}$ e $b_{1}$ estimados no delineamento em blocos casualizados. Para facilitar esta comparaçăo padronizaram-se os limites inferiores dos parámetros no delineamento em blocos casualizados como sendo zero e o limites superiores como sendo 100, para as 5 variáveis em estudo.

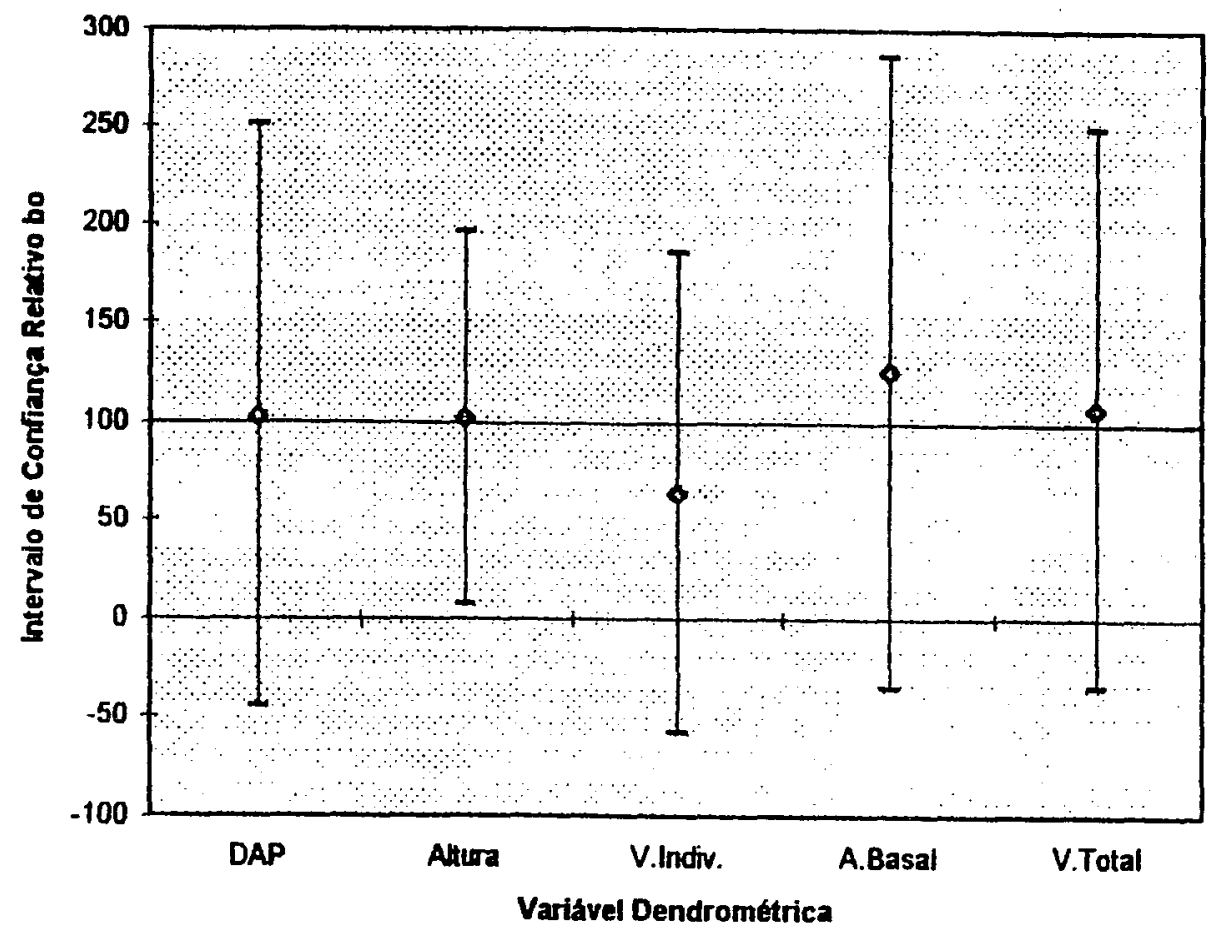

FIGURA 26. Intervalos de confiança dos parâmetros $b_{0}$, no delineamento sistemático tipo "leque", para as 5 regressões lineares das variáveis em estudos, relativamente aos intervalos de confiança do delineamento em blocos casualizados padronizados de 0 (limite inferior) a 100 (limite superior). 


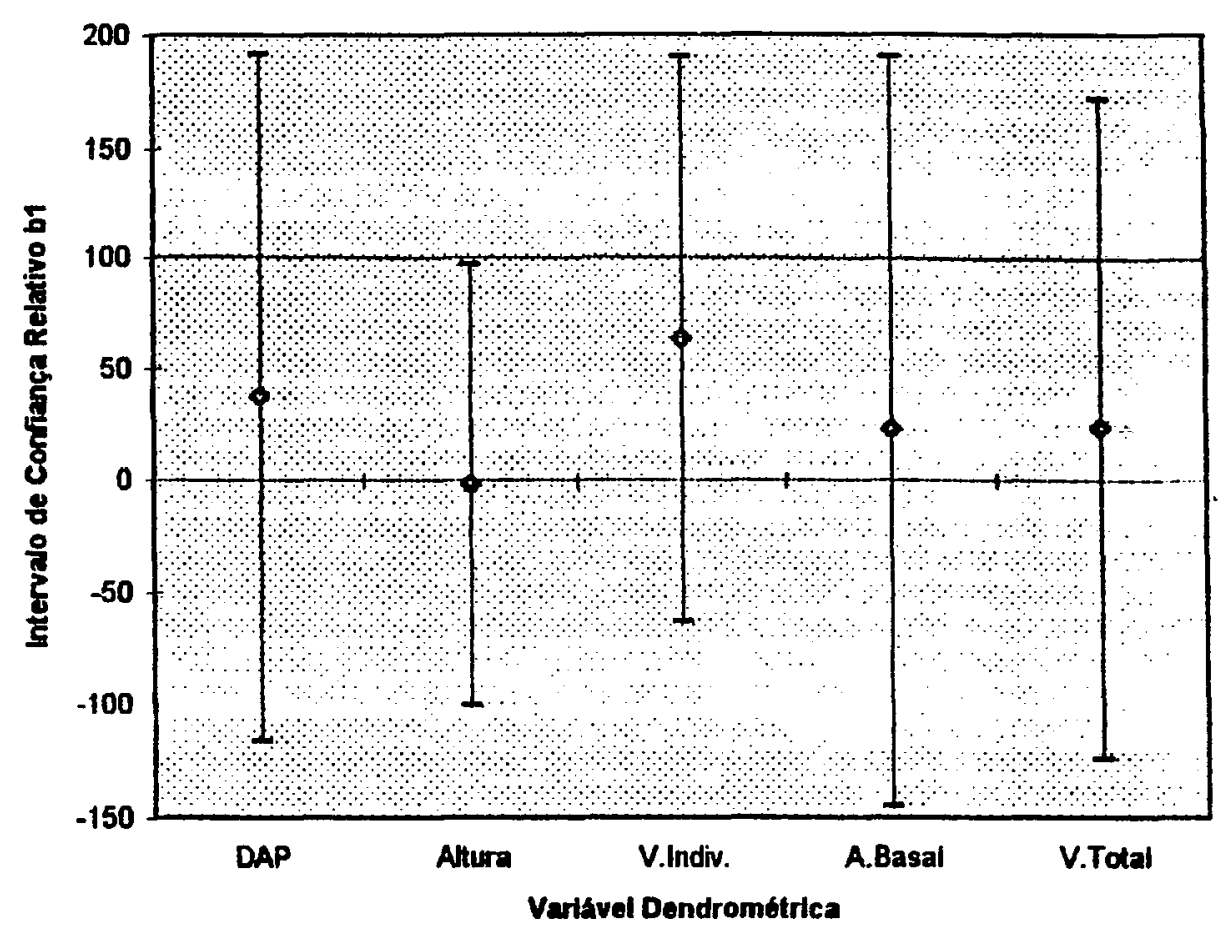

FIGURA 27. Intervalos de confiança dos parámetros $b_{1}$, no delineamento sistemático tipo "leque", para as 5 regressóes lineares das variáveis em estudos, relativamente aos intervalos de confiança do delineamento em blocos casualizados padronizados de 0 (limite inferior) a 100 (limite superior)

Pelas Figuras 26 e 27 percebe-se que os intervalos de confiança de $b_{0}$ e $b_{1}$, para as 5 variáveis em estudo, em ambos os delineamentos se sobrepóem, expressando que o E.dunnii responde de forma semelhante ao espaçamento em ambos os experimentos, na faixa similar considerada. Nota-se claramente os maiores intervalos de confiança dos coeficientes $b_{0}$ e $b_{1}$ no delineamento sistemático tipo "leque", devido à sua maior variancia residual, já comentada. Para a cultura do milho, BAUDER et alii (1975) também obtiveram regressoes para delineamento sistemático e em blocos casualizados semeihantes para todos os coeficientes, mostrando que provavelmente, para as culturas agricolas o comportamento diferenciado das variáveis de produçåo frente ao espaçamento, entre os delineamentos, seja pequeno ou nulo, em funçăo do curto ciclo das culturas (3 a 4 meses).

No entanto, para o caso florestal, uma análise mais cuidadosa da Figura 26 evidencia que o delineamento sistemático tipo "leque" possui todas as estimativas de $b_{0}$ superiores às respectivas estimativas no delineamento em blocos 
casualizados, e na sua maioria acima do seu limite superior do intervalo de confiança. O mesmo já náo ocorre para as estimativas de $b_{1}$ no delineamento sistemático tipo "leque" (Figura 27), pois as mesmas oscilam acima e abaixo da média das respectivas estimativas do delineamento em blocos casualizados.

Percebe-se, portanto, que, encoberta pela excessiva varianncia residual do delineamento sistemático tipo "leque", existe uma diferenciaçăo no comportamento do E.dunnii nos dois delineamentos, para espaçamentos semelhantes.

Para espécies florestais, o longo perlodo de crescimento e o grande alcance das raizes e copas (NAMKOONG, 1966) deve levar a essa tendéncia maior de diferenciaçáo do padrăo de resposta das variáveis de produçăo, individuais ou conjuntas, nos dois delineamentos.

No presente caso, nota-se, que para o DAP, volume individual, área basal e volume total, os dois experimentos, na faixa comum de espaçamento analisada, possuem tendéncias semelhantes de resposta ao espaçamento (coeficientes angulares $b_{1}$ similares), porém, defasados (coeficientes $b_{0}$ maiores para o delineamento sistemático). No caso da altura, por ser uma variável menos influenciável pelo espaçamento, a năo ser para espaçamentos bem adensados (BALLONI \& SIMÕES, 1980), e mais dependente da qualidade do sítio (SCHENEIDER, 1993), os valores observados em ambos experimentos, na faixa comum de espaçamento, săo muito semelhantes e as retas da regressăo linear se cruzam (Figura 22).

Assim, constatado que o delineamento sistemático tipo "leque" pode superestimar as estimativas das variáveis em estudo, e sabendo que esta observaçăo só foi possivel pela existéncia de um delineamento em blocos casualizados contiguo ao mesmo, optou-se por prosseguir na análise experimental e se fazer uma proposta de utilizaçăo dos delineamentos sistemático tipo "leque" de forma mais segura e eficiente.

Esta proposta inicia-se pela recomendaçăo básica de se implantar, concomitantemente e em área contígua ao delineamento sistemático tipo "leque", parcelas, nos plantios comerciais, com alguns espaçamentos coincidentes, com aqueles em teste no delineamento sistemático. Esta premissa básica objetiva que as 
parcelas comerciais sejam a ligaçăo entre o delineamento sistemático tipo "leque" e as condiçס̃es reais de maciço florestal.

A segunda fase da proposta pressupóe o ajuste de curvas de resposta ao espaçamento para a condiçăo de maciço florestal, numa faixa tăo grande quanto aquela testada no delineamento sistemático. Esta fase só será necessária se for detectada a diferença de comportamento entre as variáveis em estudo nas parcelas experimentais e no delineamento sistemático.

Como no presente caso encontramos fortes indicios dessa defasagem de resposta, passaremos no item 4.3.2 a esta segunda fase.

\subsubsection{Equações de Resposta ao Espaçamento no Delineamento Sistemático Tipo "Leque"}

$\mathrm{Na}$ Tabela 29 encontram-se os valores do teste $\mathrm{F}$ para regressăo, coeficiente de determinação e soma de quadrados dos erros das variáveis originais, das equaçoes ajustadas tendo como variável dependente as 5 variáveis em estudo, e como variável independente o espaçamento (Tabela 14). Para as variáveis DAP, altura e volume individual houve 50 observaçóes, enquanto para a área basal e volume total, dada a eliminaçăo das observações do tratamento 1 , existiram 45 observaçces.

Pela Tabela 29 observa-se que foi possível o ajuste de boas equaçס̄es de regressăo, para todas as 5 variáveis em estudo, em funçăo do espaçamento, mas que os modelos diferiram entre as variáveis.

Para a escolha da melhor equação considerou-se, principalmente, os menores valores da $S Q$, assim como os maiores valores de $F$ e $R^{2}$, lembrando-se que os valores de $R^{2}$ năo săo diretamente comparáveis nos modelos lineares $\mathrm{e}$ logaritmicos. Também, sem perder de vista o interesse por equações mais simples, selecionou-se, para cada variável, aquelas constantes na Tabela 30

Dentre todas as variáveis, apenas a altura foi expressa em funçăo da equaçăo inversa proposta por NELDER (1962), ficando as demais bem ajustadas por modelos polinomiais, dispensando a utilizaçăo de equaçőes năo lineares para as curvas de resposta, como a de RICHARDS (1959). 
TABELA 29. Valores de $F$ para regressáo, coeficiente de determinaçăo $\left(R^{2}\right)$ e soma de quadrados dos erros das variáveis originais (SQ) para as equaçóes de resposta ao espaçamento, para as 5 variáveis em estudo, no delineamento sistemático tipo "leque", para E.dunnii aos 71 meses.

\begin{tabular}{|c|c|c|c|c|c|c|}
\hline Modelo & Valores & DAP & ALTURA & V.IND. & A.BASAL & V.TOTAL \\
\hline & & $\mathbf{c m}$ & $\mathbf{m}$ & $\mathbf{d m}^{3} / \mathbf{p l}$ & $\mathbf{m}^{2} / \mathbf{h a}$ & $\mathbf{m}^{3} / \mathbf{h a}$ \\
\hline \multirow{3}{*}{ Linear } & $\mathrm{F}$ & $180,54^{\star \star}$ & $20,89^{\star \star}$ & $253,80^{\star \star}$ & $67,38^{\star \star}$ & $39,20^{\star \star}$ \\
& $\mathrm{R}^{2}$ & 0,790 & 0,303 & 0,841 & 0,610 & 0,477 \\
& $\mathrm{SQ}$ & 430,89 & 346,59 & 237885,55 & 1284,89 & 128904,54 \\
\hline \multirow{3}{*}{ Quadrático } & $\mathrm{F}$ & $334,01^{\star \star}$ & $35,32^{\star \star}$ & $336,86^{\star \star}$ & $38,85^{\star \star}$ & $19,33^{\star \star}$ \\
& $\mathrm{R}^{2}$ & 0,934 & 0,600 & 0,935 & 0,649 & 0,479 \\
& $\mathrm{SQ}$ & 134,86 & 198,73 & 97538,68 & 1157,18 & 128299,48 \\
\hline \multirow{3}{*}{ Cúbico } & $\mathrm{F}$ & $275,96^{\star \star}$ & $33,56^{\star \star}$ & $221,93^{\star \star}$ & $26,44^{\star \star}$ & $12,58^{\star \star}$ \\
& $\mathrm{R}^{2}$ & 0,947 & 0,686 & 0,935 & 0,659 & 0,479 \\
& $\mathrm{SQ}$ & 107,99 & 156,0 & 96659,74 & 1123,86 & 128294,54 \\
\hline \multirow{3}{*}{ Inverso } & $\mathrm{F}$ & $227,87^{\star \star}$ & $113,39^{\star \star}$ & $65,55^{\star \star}$ & & \\
& $\mathrm{R}^{2}$ & 0,826 & $0 ; 702$ & 0,577 & - & - \\
\hline \multirow{3}{*}{ Logaritmico } & $\mathrm{SQ}$ & 204,09 & 134,59 & 37840665,1 & & \\
& $\mathrm{~F}$ & & & & $141,68^{\star \star}$ & $69,22^{\star \star}$ \\
& $\mathrm{R}^{2}$ & - & - & - & 0,767 & 0,617 \\
& $\mathrm{SQ}$ & & & & 3125,34 & 279526,94 \\
\hline
\end{tabular}

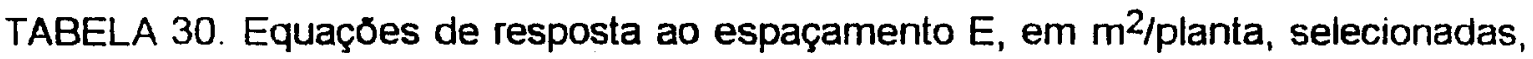
para as 5 variáveis em estudo, no delineamento sistemático tipo "leque" (s), para o E.dunnii, aos 71 meses.

\begin{tabular}{|l|l|}
\hline \multicolumn{1}{|c|}{ VARIAVEL } & \multicolumn{1}{c|}{ EQUACÄO } \\
\hline DAP $(\mathrm{cm})$ & DAP $_{s}=6,047918+1,550715 \cdot E-0,044836 \cdot E^{2}+0,000449 . E^{3}$ \\
\hline ALTURA $(\mathrm{m})$ & $\mathrm{ALT}_{\mathrm{s}}=\left(0,043206+0,042707 \cdot \mathrm{E}^{-1}\right)^{-1}$ \\
\hline V.INDIV. $\left(\mathrm{dm}^{3} / \mathrm{pl}\right)$ & $\mathrm{VIN}_{\mathrm{s}}=6,837521+25,90874 . E-0,33096 \cdot \mathrm{E}^{2}$ \\
\hline A.BASAL $\left(\mathrm{m}^{2} / \mathrm{ha}\right)$ & $\mathrm{ABA}_{\mathrm{s}}=31,798023-0,498670 . E$ \\
\hline V.TOTAL $\left(\mathrm{m}^{3} / \mathrm{ha}\right)$ & $\mathrm{VOL}_{s}=277,417077-3,809628 . E$ \\
\hline
\end{tabular}

Nas Figuras 28, 29, 30, 31 e 32 estăo traçadas as equações determinadas para DAP, altura, volume individual, área basal e volume total, respectivamente. Nota-se, portanto, que a utilizaçăo de regressăo na interpretaçăo do delineamento sistemático tipo "leque" é, sem dúvida alguma, a forma mais acertada para sua análise (NELDER,1962; NAMKOONG, 1967; EVERT,1971; WRIGHT,1976; HUXLEY \& MAINGU,1978; HUXLEY,1985; MEAD, 1988 e PEARCE, 1989) 


\subsubsection{Equaçōes de Resposta ao Espaçamento Ajustadas para o Delineamento em Blocos Casualizados}

Com base nas equaçoes constantes na Tabela 30, na convergéncia de resposta das variáveis admitida para o espaçamento de 43,95 $\mathrm{m}^{2} /$ planta, e no valor médio do delineamento em blocos casualizados (Figura 10), obtiveram-se as equaçóes de resposta ao espaçamento ajustadas para o delineamento em blocos casualizados, discriminadas na Tabela 31.

TABELA 31. Equaçóes de resposta ao espaçamento $E$, em $\mathrm{m}^{2} /$ planta, para o DAP, altura, volume individual, área basal e volume total, ajustadas para o delineamento em blocos casualizados (b), para E.dunnii, aos 71 meses.

\begin{tabular}{|c|c|}
\hline VARIÁVEL & EQUAÇẢO \\
\hline $\operatorname{DAP}(\mathrm{cm})$ & $D_{A P} P_{b}=5,494978+1,563296 \cdot E-0,044836 \cdot E^{2}+0,000449 \cdot E^{3}$ \\
\hline ALTURA (m) & $A L T_{b}=0,352796-0,008027 \cdot E+\left(0,043206+0,042707 \cdot E^{-1}\right)^{-1}$ \\
\hline V.INDIV. $\left(\mathrm{dm}^{3} / \mathrm{pl}\right)$ & $V I N_{b}=-6,883828+26,220944 \cdot E-0,33096 \cdot E^{2}$ \\
\hline A.BASAL ( $\left.\mathrm{m}^{2} / \mathrm{ha}\right)$ & $A B A_{b}=27,483629-0,400504 . E$ \\
\hline V.TOTAL $\left(\mathrm{m}^{3} / \mathrm{ha}\right)$ & $\mathrm{VOL}_{b}=253,066080-3,255567 . \mathrm{E}$ \\
\hline
\end{tabular}

As equações de resposta do DAP, altura, volume individual, área basal e volume total ao espaçamento, ajustadas para blocos casualizados, såo apresentadas nas Figuras 28, 29, 30, 31 e 32, respectivamente.

Observa-se portanto, que a existência do delineamento em blocos casualizados, em área contigua e com alguns tratamentos comuns ao delineamento sistemático tipo "leque", possibilitou a detecção do padrăo diferenciado de comportamento das variáveis em estudo, entre os dois experimentos. Além disso, possibilitou o ajuste das estimativas dessas variáveis, obtidas numa ampla faixa de espaçamentos do delineamento sistemático, para a situaçăo de blocos casualizados, a qual representa o comportamento do E.dunnii em condiçőes de plantio homogêneo e equiâneo para fins comerciais 


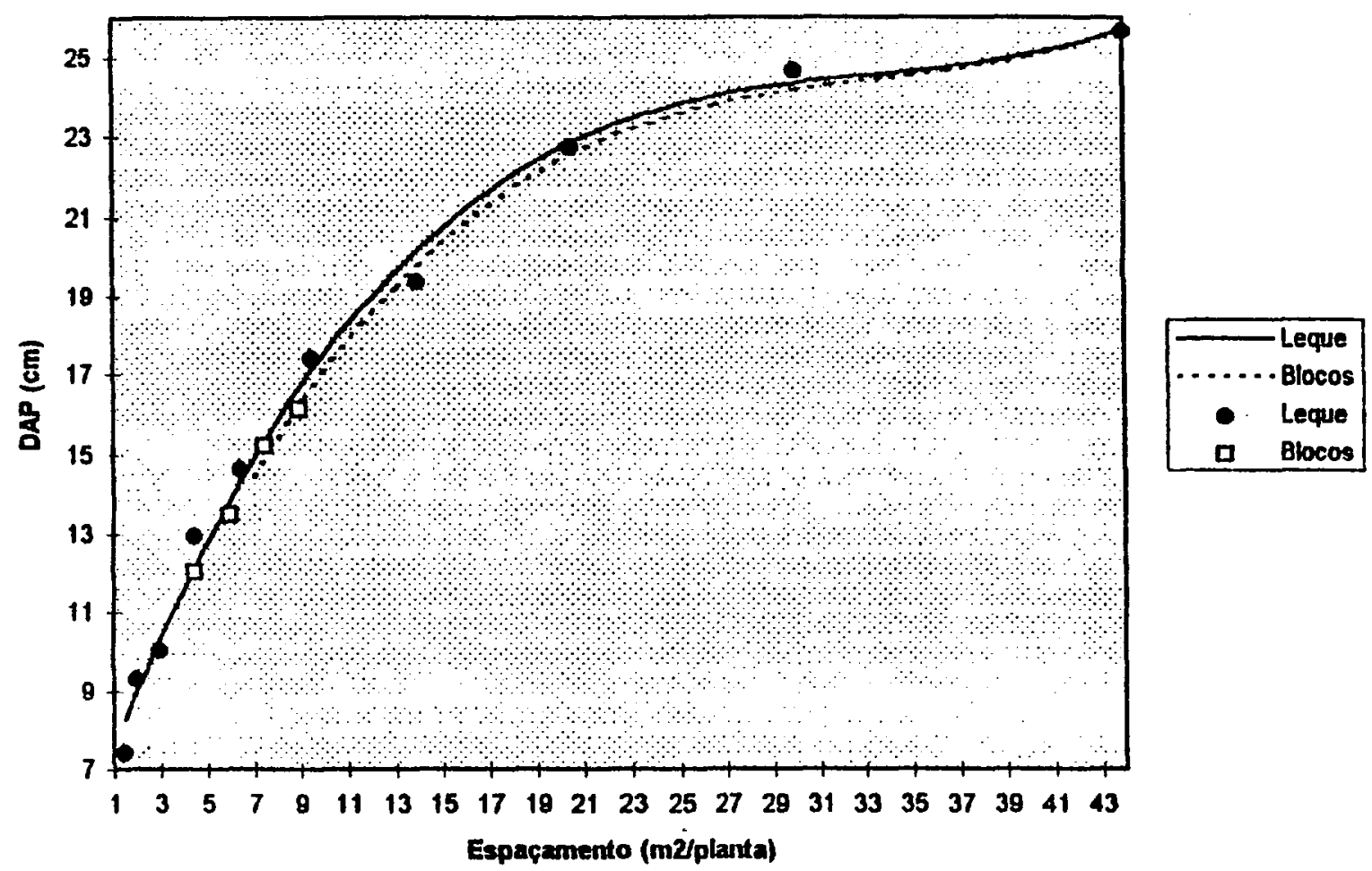

FIGURA 28. Equaçoes de resposta do DAP em funçăo do espaçamento para o E.dunnii, aos 71 meses, no delineamento sistemático tipo "leque" e a respectiva equaçăo ajustada para blocos casualizados.

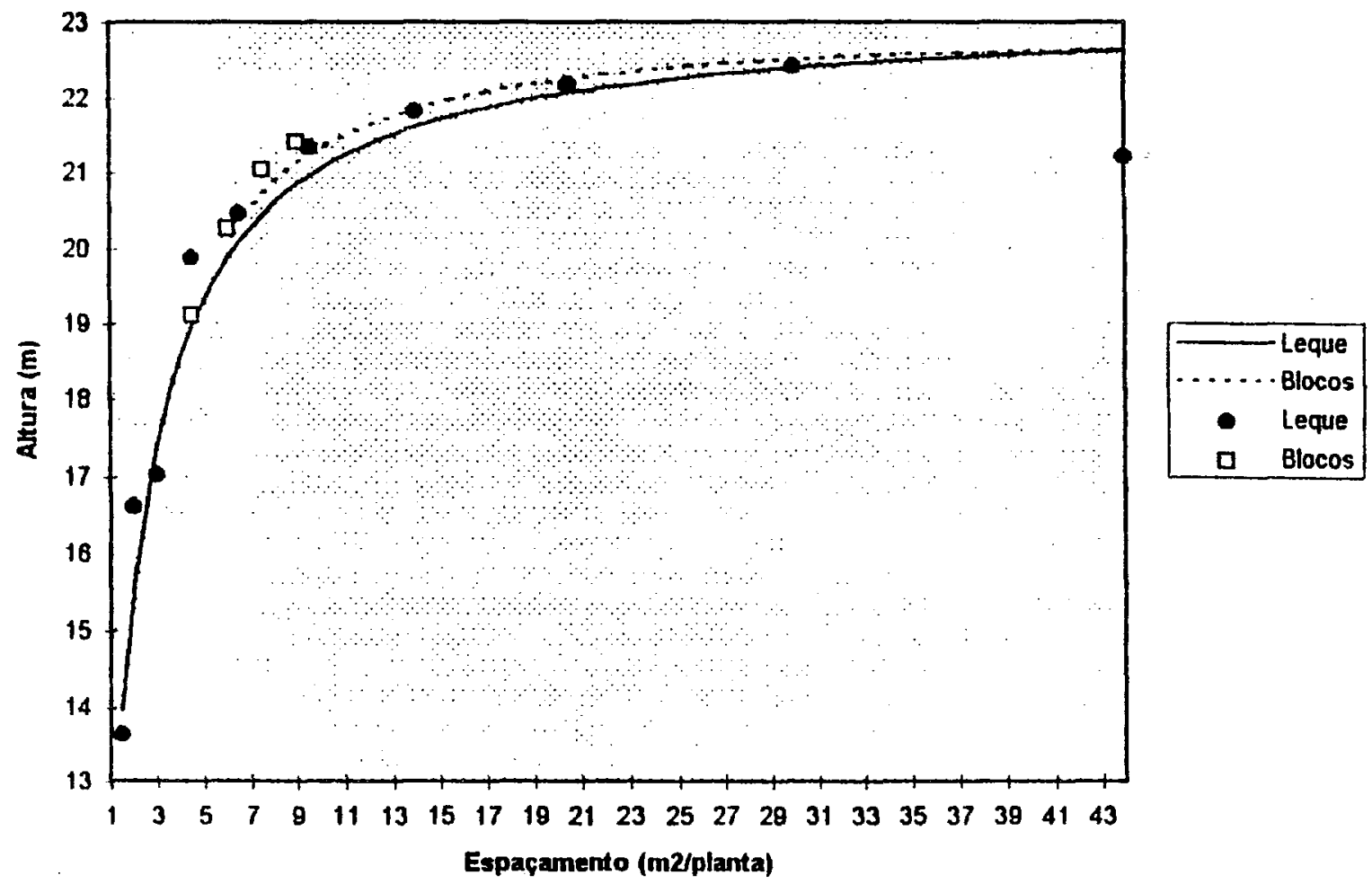

FIGURA 29. Equações de resposta da altura em função do espaçamento para o E dunnii, aos 71 meses, no delineamento sistemático tipo "leque" e a respectiva equaçăo ajustada para blocos casualizados. 


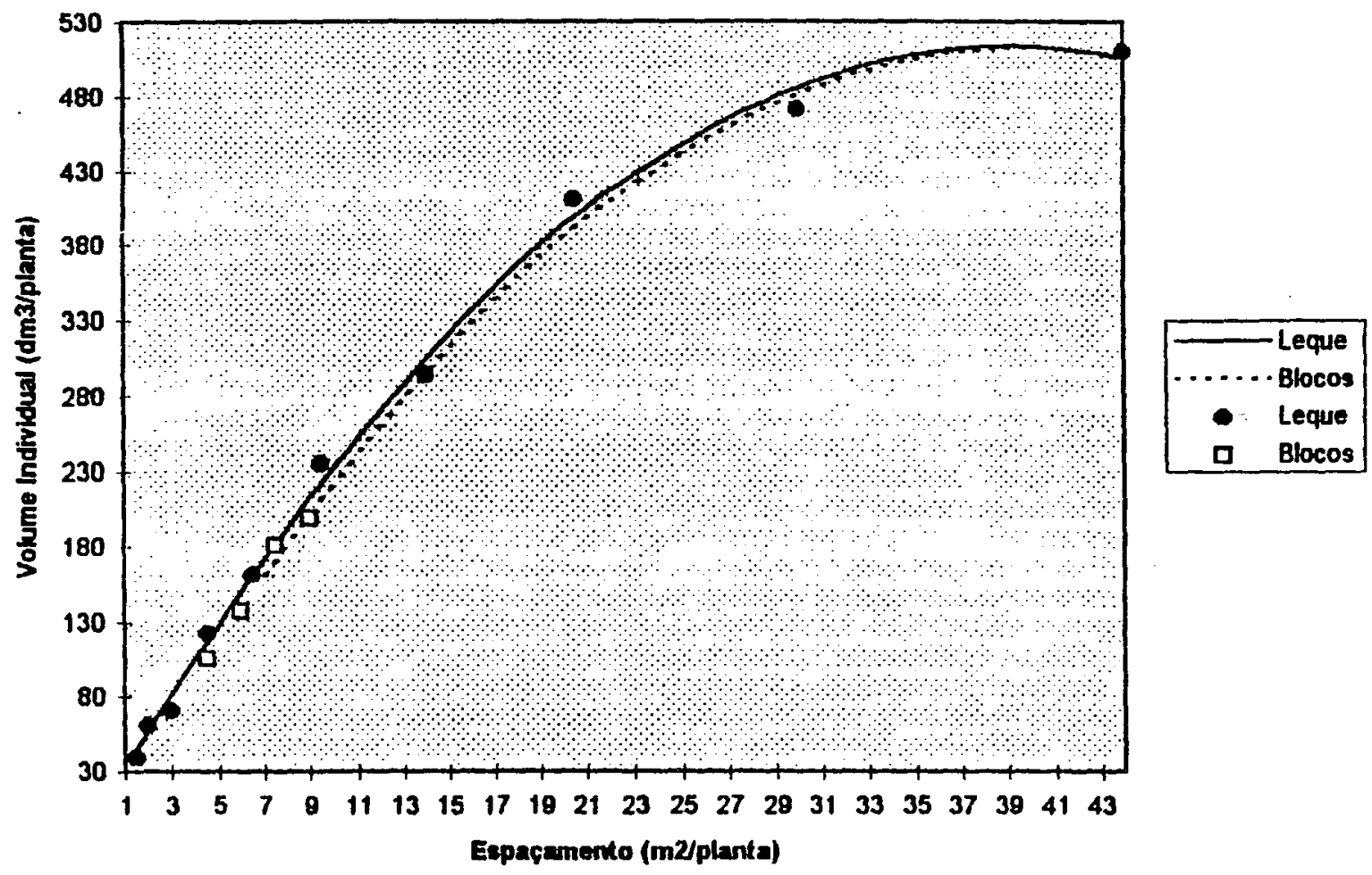

FIGURA 30. Equaçóes de resposta do volume individual em funçăo do espaçamento para o E.dunnii, aos 71 meses, no delineamento sistemático tipo "leque" e a respectiva equaçăo ajustada para blocos casualizados.

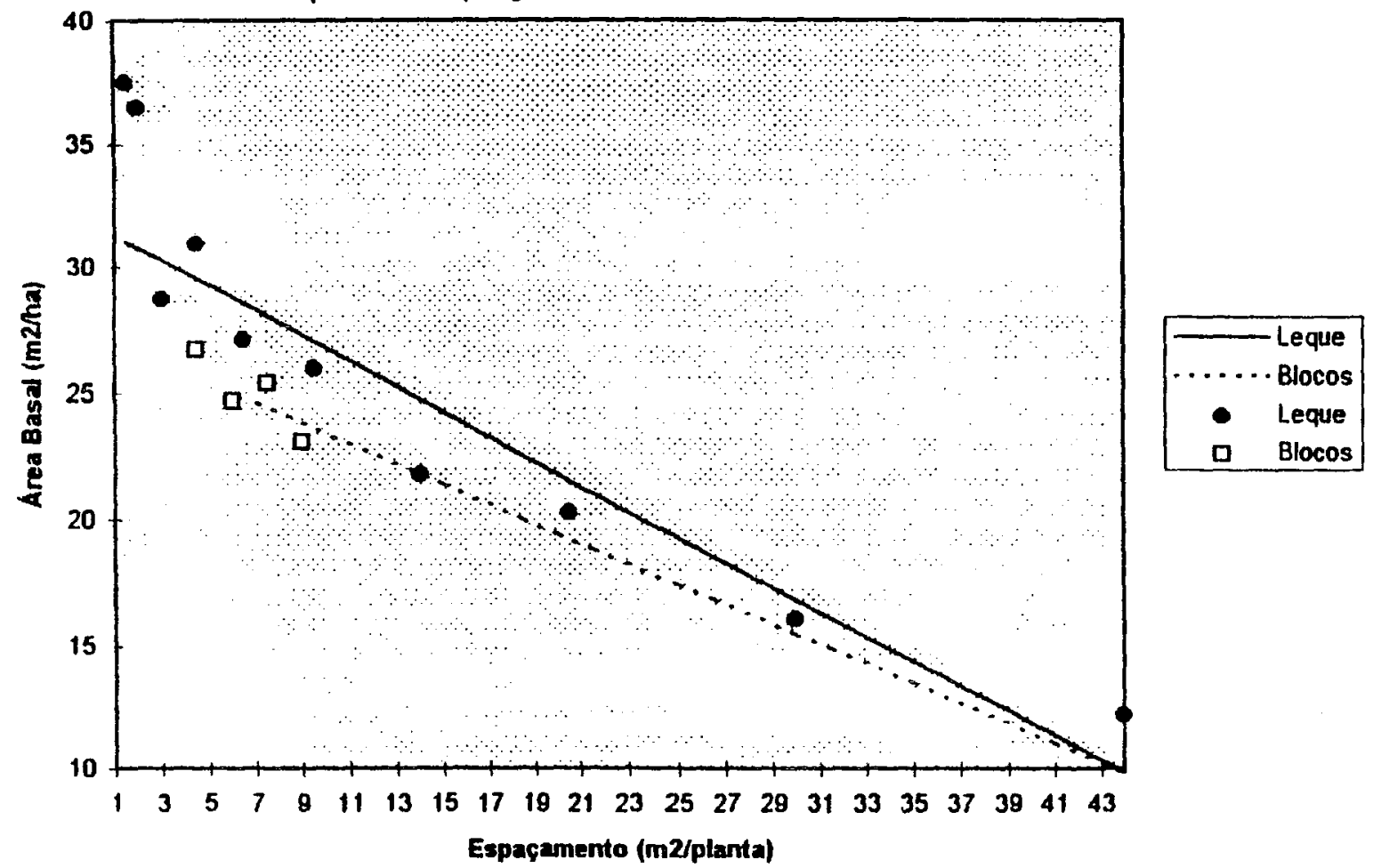

FIGURA 31. Equaçóes de resposta da área basal em funçăo do espaçamento para o E.dunnii, aos 71 meses, no delineamento sistemático tipo "leque" e a respectiva equaçăo ajustada para blocos casualizados. 


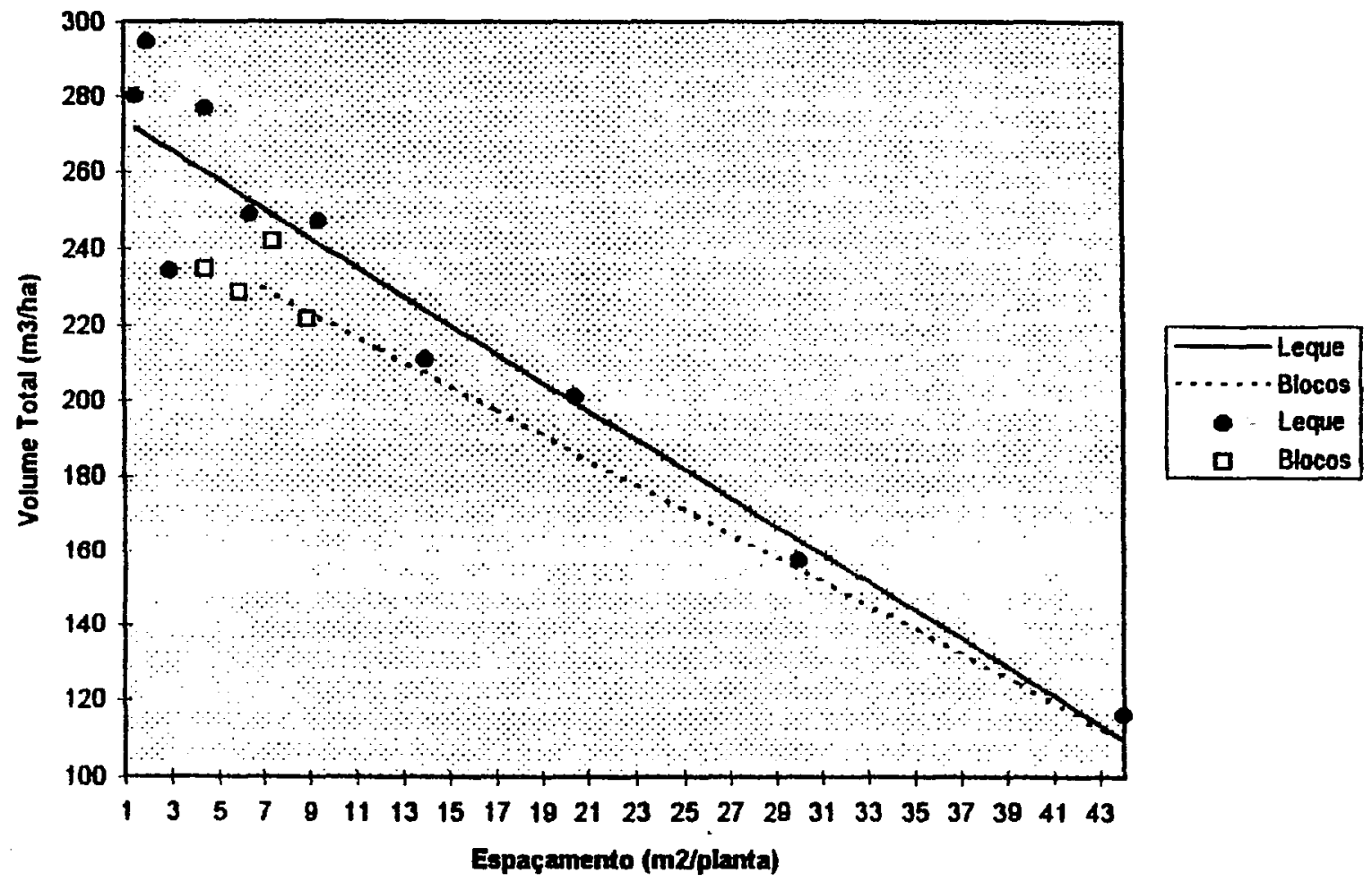

FIGURA 32. Equaçóes de resposta do volume total em funçăo do espaçamento para o E.dunnii, aos 71 meses, no delineamento sistemático tipo "leque" e a respectiva equaçăo ajustada para blocos casualizados

Assim, propoe-se que o uso dos delineamentos sistemáticos tipo "leque" no estudo de espaçamentos florestais deva estar sempre associado a parcelas de "referéncias", no plantio comercial, plantadas simultaneamente e em área contigua ao delineamento sistemático tipo "leque" e contendo espaçamentos comuns em relaçăo a este. Recomenda-se que estas parcelas sinvam para aferir os resultados obtidos no delineamento sistemático, bem como para corrigir os possiveis padrões de respostas das variáveis em estudo em funçăo do espaçamento. Evitar-se-á, assim, a extrapolaçăo indevida dos resultados do experimento sistemático tipo "leque" para as condiçoes de maciço florestal.

Além deste aspecto, as parcelas "referéncias" possibilitarâo a eliminaçáo da fase de comprovaçáo dos resultados do delineamentos sistemáticos, apregoados por HUXLEY (1985), PEARCE (1989) e RAO et alii (1990). Esta fase se refere a utilizaçăo de poucos tratamentos em experimentos robustos com aleatorizaçăo, para a faixa de espaçamento que mostrou potencial de utilizaçăo num delineamento sistemático "exploratório". Evidentemente, para a área agricola, onde as culturas possuem ciclos curtos de 3 a 4 meses, esta fase de comprovaçăo é factivel 
dentro de um mesmo ano agricola. Entretanto, esta prática, se adotada na área florestal manejada com Eucalyptus, onde os ciclos mínimos são de 6 a 11 anos, acarretaria uma demora significativa para aplicaçăo dos resultados (12 a 22 anos). A utilizaçăo das parcelas de "referencia" reduz pela metade este prazo, ou seja, os dados seriam utilizados para direcionar os plantios comerciais concomitantemente a avaliaçăo do delineamento sistemático tipo "leque", nas diferentes idades de manejo consideradas.

Desta forma, săo extremamente procedentes as ponderaçoes efetuadas por MEAD (1988) e RAO et alii (1990) de que o uso dos delineamentos sistemáticos de fator quantitativo contínuo deve ser visto náo sobre a ótica estrita da estatistica, mas sim através de um consenso entre sua aplicabilidade agronómica, sua limitaçóes estatísticas e sua segurança de extrapolaçáo de resultados.

Para exemplificar esta proposta de utilização dos delineamentos sistemáticos tipo "leque" no estudo de espaçamentos florestais, săo apresentados, no item 4.3.5, dois exemplos ilustrativos de sua aplicabilidade nas situaçoes práticas do dia-a-dia florestal.

\subsubsection{Exemplos llustrativos do Uso das Equaçöes Ajustadas}

\subsubsection{Exemplo 1}

Este primeiro exemplo tabula os valores das equaçoes de resposta das variáveis DAP, volume individual e volume total, do delineamento sistemático tipo leque $\left(y_{s}\right)$ e ajustado para blocos casualizados $\left(y_{b}\right)$, numa faixa de 10,0 a 20,0

$\mathrm{m}^{2} /$ planta, para que se constate a magnitude dos desvios entre os valores do delineamento sistemático tipo "leque" e aquele esperado para condiçóes de maciço, para o E. dunnii, aos 71 meses (Tabela 32). 
TABELA 32. Valores estimados para o DAP, volume individual e volume total, no delineamento sistemático tipo "leque" (SL), e respectivos valores ajustados para condiçâo de blocos casualizados (BC), e relação percentual entre ambos, numa faixa de 9,5 a $15,0 \mathrm{~m}^{2} /$ planta, para E.dunnii, aos 71 meses.

\begin{tabular}{|c|c|c|c|c|c|c|c|c|c|}
\hline \multirow{2}{*}{$\begin{array}{l}\text { Espac } \\
\left(\mathrm{m}^{2} / p \mid\right)\end{array}$} & \multicolumn{3}{|c|}{$\begin{array}{l}\text { DAP } \\
\text { (cm) }\end{array}$} & \multicolumn{3}{|c|}{$\begin{array}{l}\text { Vol. Individual } \\
\text { (dm } 3 / \text { planta) }\end{array}$} & \multicolumn{3}{|c|}{$\begin{array}{c}\text { Volume Total } \\
\left(m^{3} / h a\right)\end{array}$} \\
\hline & $\mathbf{S L}$ & $B C$ & $\%$ & $\mathbf{S L}$ & $B C$ & $\%$ & $S L$ & $B C$ & $\%$ \\
\hline 10,0 & 17,52 & 17,09 & 2,5 & 232,83 & 222,23 & 4,8 & 239,32 & 220,51 & 8,5 \\
\hline 11,0 & 18,28 & 17,86 & 2,3 & 251,79 & 241,50 & 4,3 & 235,51 & 217,25 & 8,4 \\
\hline 12,0 & 18,98 & 18,57 & 2,2 & 270,08 & 260,11 & 3,8 & 231,70 & 214,00 & 8,3 \\
\hline 13,0 & 19,62 & 19,23 & 2,0 & 287,72 & 278,06 & 3,5 & 227,89 & 210,74 & 8,1 \\
\hline 14,0 & 20,20 & 19,83 & 1,9 & 304,69 & 295,34 & 3,2 & 224,08 & 207,49 & 8,0 \\
\hline 15,0 & 20,74 & 20,37 & 1,8 & 321,00 & 311,96 & 2,9 & 220,27 & 204,23 & 7,9 \\
\hline 16,0 & 21,22 & 20,87 & 1,7 & 336,65 & 327 , & 2,7 & 216,46 & 200,98 & 7,7 \\
\hline 17,0 & 21,66 & 21,32 & 1,6 & 351,64 & 343,22 & 2,5 & 212,65 & 197,72 & 7,6 \\
\hline 18,0 & 22,05 & 21,73 & 1,5 & 365,96 & 357,86 & 2,3 & 208,84 & 194,47 & 7,4 \\
\hline 19,0 & 22,41 & 22,09 & 1,4 & 379,63 & 371,84 & 2,1 & 205,03 & 191,21 & 7,2 \\
\hline 20,0 & 22,72 & 22,42 & 1,3 & 392,63 & 385,15 & 1,9 & 201,22 & 187,95 & 7,1 \\
\hline
\end{tabular}

\subsubsection{Exemplo 2}

Qual deveria ser o espaçamento de plantio do E.dunnii, para fins de produçăo de celulose, para se obter aos 71 meses, na idade de corte, o maior diametro médio do povoamento e produçăo minima de $200 \mathrm{~m}^{3} / \mathrm{ha}$, necessárias, supostamente, para viabilizar economicamente a exploração com "harvester" ?

Como o diâmetro é crescente com o aumento do espaçamento e o volume total decrescente, podemos resolver diretamente a equaçăo (Tabela 31):

$$
V_{O L}=253,066080-3,255567 . E
$$

que para $\mathrm{VOL}_{b}=200,0 \mathrm{~m}^{3} / \mathrm{ha}$ fornece $E=16,30 \mathrm{~m}^{2} /$ planta, espaçamento que aplicado na equaçăo do DAP $_{b}$ (Tabela 31):

$$
D A P_{b}=5,494978+1,563296 \cdot E-0,044836 \cdot E^{2}+0,000449 \cdot E^{3}
$$


estima o DAP $P_{b}$ em $21,01 \mathrm{~cm}$, na idade de corte.

Assim, poder-se-ja, comercialmente, adotar-se um plantio de 4,04 $\mathrm{m} \times$ $4,04 \mathrm{~m}$ para obterem-se os valores desejados, aos 71 meses para o E.dunnii, em regiấo edafoclimática semelhante.

A consulta à Tabela 32 levaria também a obtençăo de resultado aproximado, destacado em negrito na mesma.

\subsubsection{Aspectos Operacionais da Conduçăo dos Experimentos}

Conduzidos em áreas contlguas, e tendo os mesmos tratos culturais, evidenciou-se a maior facilidade de instalaçăo e avaliaçăo do delineamento sistemático tipo "leque", como já observado por NELDER (1962), FREEMAN (1966), MINAMI (1977), NAMKOONG (1967), CLEAVER et alii (1970) e WRIGHT (1976).

No entanto, o arranjo em "leque" impossibilita o uso de máquinas nos tratos culturais como o controle de ervas daninhas, fertilizaçâo etc, operaçóes essas que necessitam ser realizadas manualmente.

A ocorréncia de 5 falhas, embora pequeno, e contornável no presente estudo através do rearranjo das parcelas experimentais, alerta sobre a extremo zelo que necessitam os experimentos implantados com este delineamento, para năo dificultar sua análise (DRAPPER \& GUTTMAN, 1980; WILKINSON et alii 1983; BESAG \& KEMPTON, 1986; LAND \& NANCE, 1987), ou mesmo inutilizá-lo (NELDER, 1962; WRIGHT, 1976; PEARCE, 1989). 


\section{CONCLUSÖES}

Com base nos resultados obtidos nos experimentos de espaçamento para E.dunnii, com delineamentos em blocos casualizados e sistemático tipo "leque", pode-se concluir que:

O delineamento sistemático tipo "leque" reproduziu, numa pequena área, o comportamento, individual (DAP, altura e volume individual) e conjunto (área basal e volume total), das plantas frente ao espaçamento, de forma semeihante àquele observado no delineamento em blocos casualizados;

O delineamento sistemático tipo "leque" possibilitou conhecer os padróes de resposta do E.dunnii ao espaçamento, tanto em termos de crescimento individual como conjunto, numa amplitude que dificilmente seria avaliada via delineamentos aleatórios tradicionais;

A análise de regressão mostrou ser ferramenta estatística adequada no estudo de espaçamentos florestais quando se utiliza o delineamento sistemático tipo "leque",

O delineamento sistemático tipo "leque" necessita, para sua correta análise e interpretaçăo, de parcelas "refêrencias" contiguas, plantadas em condições de maciço florestal; 
- Com base nessas parcelas "referéncias" pode-se estabelecer equaçóes de respostas, das variáveis dendrométricas ao espaçamento, ajustadas para a condiçâo de maciço florestal, na ampla faixa de espaçamentos ensaiada no delineamento sistemático tipo "leque";

- A escolha de área uniforme, o plantio de material genético melhorado e a execução de tratos culturais criteriosos, sáo premissas fundamentais para a utilizaçăo bem sucedida dos delineamento sistemático tipo "leque" no estudo de espaçamentos florestais. 


\section{REFERENCIAS BIBLIOGRAFICAS}

ASSMANN,E. The principles of forest yield study. Oxford, Pergamon Press, 1970. $506 p$.

BALLONI,E.A. \& SIMŌES,J.W. O espaçamento de plantio e suas implicaçóes silviculturais. Série Técnica IPEF, Piracicaba, 1(3):1-16, 1980.

BAUDER,J.W.; HANKS,R.J.; JAMES,D.W. Crop production function determinations as influenced by irrigation and nitrogen fertilization using a continuous variable design. Soil Science Society of America Proceedings, Madison, 39:1187-92, 1975.

BERRY,G. A mathematical model relating plant yield with arrangement for regularly spaced crops. Blometrics, Washington, 505-15, 1967

BESAG,J. \& KEMPTON,R. Statistical analysis of field experiments using neighbouring plots. Biometrics, Washington, 42: 231-51, June 1986.

BLEASDALE,J.K.A. Systematic designs for spacing experiments. Experimental Agriculture, London, 3: 73-85, 1966.

CANNON,P. Espaciamiento en plantaciones de Eucalyptus: una revision e interpretacion de la literatura especialmiente para Colombia. Informe de Investigación, Cali, 73: 1-7, 1981. 
CHALITA, M.A.C. Delineamentos sistemáticos. Piracicaba, 1991. 72p. (Mestrado Escola Superior de Agricultura "Luiz de Queiróz"/USP).

CLEAVER,T.J.; GREENWOOD,D.J.; WOOD,J.T. Systematically arranged fertilizer experiments. Journal of Horticultural Science, Ashford, 45: 457-69, 1970.

COCHRAN,W.G. \& COX,G.M. Diseños experimentales. México, Editorial Trillas, 1978. 661p.

COUTO,H.T.Z.do \& BASTOS,N.L.M. Modelos de equaçoes de volume e relaçóes hipsométricas para plantaçóes de Eucalyptus no Estado de Såo Paulo. IPEF, Piracicaba, (37): 33-44, 1987.

COX,D.R. Some systematic experimental designs. Blometrika, London, 38: 312-23, 1951.

COX,D.R. Planning of experiments. New York, John Wiley, 1958. 308p.

DAWKINS,HC. The pudden clinal plot: thinning experiments without surrounds Empire Forestry Review, Oxford, 39: 168-71, 1960.

DRAPPER,N.R. \& GUTTMAN,I. Incorporating overlap effects from neighbouring units into response surface models. Applied Statistical, London, 29(2): 128-34, 1980.

DRAPPER,N.R. \& SMITH,H. Applied regression analysis. New York, John Wiley, 1981. 709p.

EMBRAPA Zoneamento ecológico para plantios florestais no estado do Paraná. Curitiba, MAVEMBRAPA/CNPF/PNPF, 1986.89p. 
EVERT,F. Spacing studies - a review. Ottawa, Canadian Forestry Service, 1971. 95p. (INFORMATION REPORT, FMR-X-37).

FAO Eucalyptus for planting. Roma, FAO, 1981.677p.

FINGER,C.A.G. Fundamentos de biometria florestal. Santa Maria, UFSM/ CEPEF/ FATEC, 1992. 269p.

FINCH,S.; SKINNER,G.; FREEMAN,G.H. The effect of plant density on populations of the cabbage root fly on four cruciferous crops. Annals of Applied Biology; London, 83:191-7, 1976.

FISHER,R. The design of experiments. Edinburg, Oliver and Boyd, 1935. 252p

FOX,R.L. Agronomic investigations using continuous function experimental designs nitrogen fertilization of sweet corn. Agronomy Journal, Madison, 65: 454-6, May/June 1973.

FREEMAN, G.H. The use of a systematic design for a spacing trial with a tropical tree crop. Biometrics, Washington, 20: 200-3, Mar. 1964.

FREEMAN,G.H. Systematic design. In: KOTS,S.; JOHNSON,N.L.; READ,C.B. ed Encyclopedia of Statistical Sciences. New York, John Wiley, 1988. v.9, p.1437.

FREYMAN,S. \& DOLMAN,D. A simple systematic design for planting density experiments with set row widths. Canadian Journal of Plant Science, Ottawa, 51:340-2, 1971. 
GOLFARI,L.; CASER,R.L.; MOURA,V.P.G. Zoneamento esquemático para reflorestramento no Brasil. Série Técnica Prodepef, Brasilia, 11: 1-66, 1978.

GOMES,F.P. \& COUTO,H.T.Z. O tamanho ótimo de parcela experimental para ensaios com eucalipto. IPEF, Piracicaba, 31: 75-8, 1985.

GOMEZ,K.A. \& DEDATTA,S.K. Missing hills in rice experimentation plots. Agronomy Journal, Madison, 64:163-4, 1972.

HILLIS,W.E. \& BROWN,A.G. Eucalyptus for wood production. Melbourne, CSIRO, 1978 433p.

HOLLIDAY,R. Plant population and crop yield. Nature, Washington, 186: 22-4, 1960

HUXLEY,P.A. Systematic designs for field experimentation with multipurpose trees. Agroforestry Systems, The Hague, 3:197-207, 1985.

HUXLEY,P.A. \& MAINGU,Z. Use of a systematic spacing design as an aid to the study of inter-cropping: some general considerations. Experimental Agriculture, London, 14: 49-56, 1978.

INSTITUTO BRASILEIRO DE DESENVOLVIMENTO FLORESTAL Estatistica de reflorestamento. Brasilia, IBDF, 1988. 25p.

KRONKA, F.J.N; MATSUKUMA,C.K., NALON,M.A.; CALI,I.H., ROSSI,M., MATTOS,IF.A.; PONTINHAS,A.A.S.; IKE,M.S.S. Inventário florestal do Estado de São Paulo. In: CONGRESSO FLORESTAL BRASILEIRO, 7., Curitiba, 1993, Anais. SBS/SBEF, 1993, v3, p.520-1. 
LAND,S.B.Jr \& NANCE,W.L. Apa: a useful tool for analyses of progeny tests. In: SOUTHERN FOREST TREE IMPROVEMENT CONFERENCE, 19., College Station, 1987. Proceedings, New Orleans, SFES, 1987. p.300-11.

LIN,C.S. \& MORSE,P.M. A compact design for spacing experiments. Biometrics, Washington, 31: 661-71, Sept. 1975.

LUTWICK,L.E.; KOZUB,G.C.; SMITH,A.D. A two-factor systematic design for fertilizer studies. Canadian Journal of Soil Science, Ottawa, 60: 657-63, 1980.

MEAD,R. The design of experiments: statistical principles for practical application. Cambrigde, University Press, 1988. 620p.

MINAMI,K. Análise de crescimento e densidade de populaçăo de Solanum melonngera L. - Berinjela, cultivada em delineamento sistemático e convencional. Piracicaba, 1977. 81p. (Mestrado - Escola Superior de Agricultura "Luiz de Queiróz"(USP).

MONTEIRO,R.F.R. \& CORDEIRO,J.A. Observaçס̋es sobre o comportamento de Eucalyptus dunnii Maiden. Notas Klabin Paraná, Tele̊maco Borda, 11p. 1983.

MURTRIE,R.Mc \& WOLF,L. A model of competition between trees and grass for radiation, water and nutrients. Annals of Botany, London, 52: 449-58, 1983

MYERS,C.C.; BRAGA,G.R.; BURNETT,F.B. Delineamento sistemático para avaliar o efeito de espaçamento no desenvolvimento de Eucalyptus alba Reinw. em Minas Gerais Silvicultura em Så Paulo, Sáo Paulo, 7:35-8, 1970

NAMKOONG,G. Application of Nelder's designs in tree improvment research. In: SOUTHERN CONFERENCE ON FOREST TREE IMPROVEMENT, 8., Savannah, 1965. Proceedings. Macon, SCFTI, 1966. p.24-37. 
NELDER,J.A. New kinds of systematic designs for spacing experiments. Biometrics, Washington, 18: 283-307, 1962.

PEARCE,S.C. The agriculture field experiment: a statistical examination of theory and practices. Chichester, John Wiley, 1989. 335p.

PEREIRA, J.C.D.; HIGA,A.R.; SHIMIZU,J.Y.; HIGA,R.C.V. Comparaçáo da qualidade da madeira de trés procedéncias de Eucalyptus dunnii Maiden, para fins energéticos. Boletim de Pesquisa Florestal, Curitiba, 13: 9-16, 1986.

RAO,M.R.; SHARMA,M.M.; ONG,C.K. A study of the potencial of hedgerow intercropping in semi-arid India using a two-way systematic design. Agroforestry Systems, The Hauge, 11:243-58, 1990.

RICHARDS,J. A flexible growth functions for empirical lise. Journal of Experimental Botany, Oxford, 10: 290-300, 1959.

RIZZO,L.T.B. Levantamento semi-detalhado dos solos da fazenda lbiti. Americana, Ripasa S/A Celulose e Papel, 1984. 111p.

ROGERS,I.S. Practical considerations in the use of systematic spacing designs. Australian Journal of Experimental Agriculture and Animal Husbandry, 12: 306-9, 1972.

SALMINEN,H. \& VARMOLA,M. Influence of initial spacing and planting design on the development of young Scots pine (Pinus sylvestris L.) stands. Silva Fennica, Helsirik, 27 (1):21-8, 1993.

SCHNEIDER,P.R. Introduçăo ao manejo florestal. Santa Maria, UFSM, i993. $348 p$. 
SCOTT,J.F. Statistical objections to clinal plots. Empire Forestry Review, Oxford, 41 : 17-8, 1962.

SMITH,J.H.G. Better yields through wider spacing. Journal of Forestry, Washington, 66(7): 492-7, 1958.

TENNENT, J.H.G. Competition quotient in young Pinus radiata. New Zealand Journal of Forestry Science, Rotorua, 6 (2):230-4. 1975.

WAHUA,TA.T \& MILLER,D.A. Relative yield totals and yield components of intercropped sorghum and soybeans. Agronomy Journal, Madison, 70: 287-91, 1978.

WALTERS,G.A. Saligna eucalyptus growth in a 15-year-old spacing study in Hawaii. Berkeley, USDA/PSFRES, 1980. 6p.

WILKINSON,G.N.; ECKERT,S.R.; HANCOCK,T.W.; MAYO,O. Nearest neighbour (NN) analysis of field experiments. Journal of Royal Statistical Society B, London, 45(2): 151-211, 1983.

WILLEY,R.W. \& RAO,M.R. A systematic design to examine effects of plant population and spacial arrangment in intercropping, illustrated by an experiment on chickpea/safflower. Experimental Agriculture, London, 17: 68-73, 1981

WRIGHT,H.L. Experiments as a source of data for growth models. In: IUFRO WORLD CONGRESS, 16., Oslo, 1976. Proceedings. Oslo, IUFRO, 1976, v. 1 p.60-73

YATES,F. The comparative advantages of systematic and randomized arrangements in the design of agricultural and biological experiments. Biometrika, London, 30:440-66, 1938. 


\section{APÊNDICE}

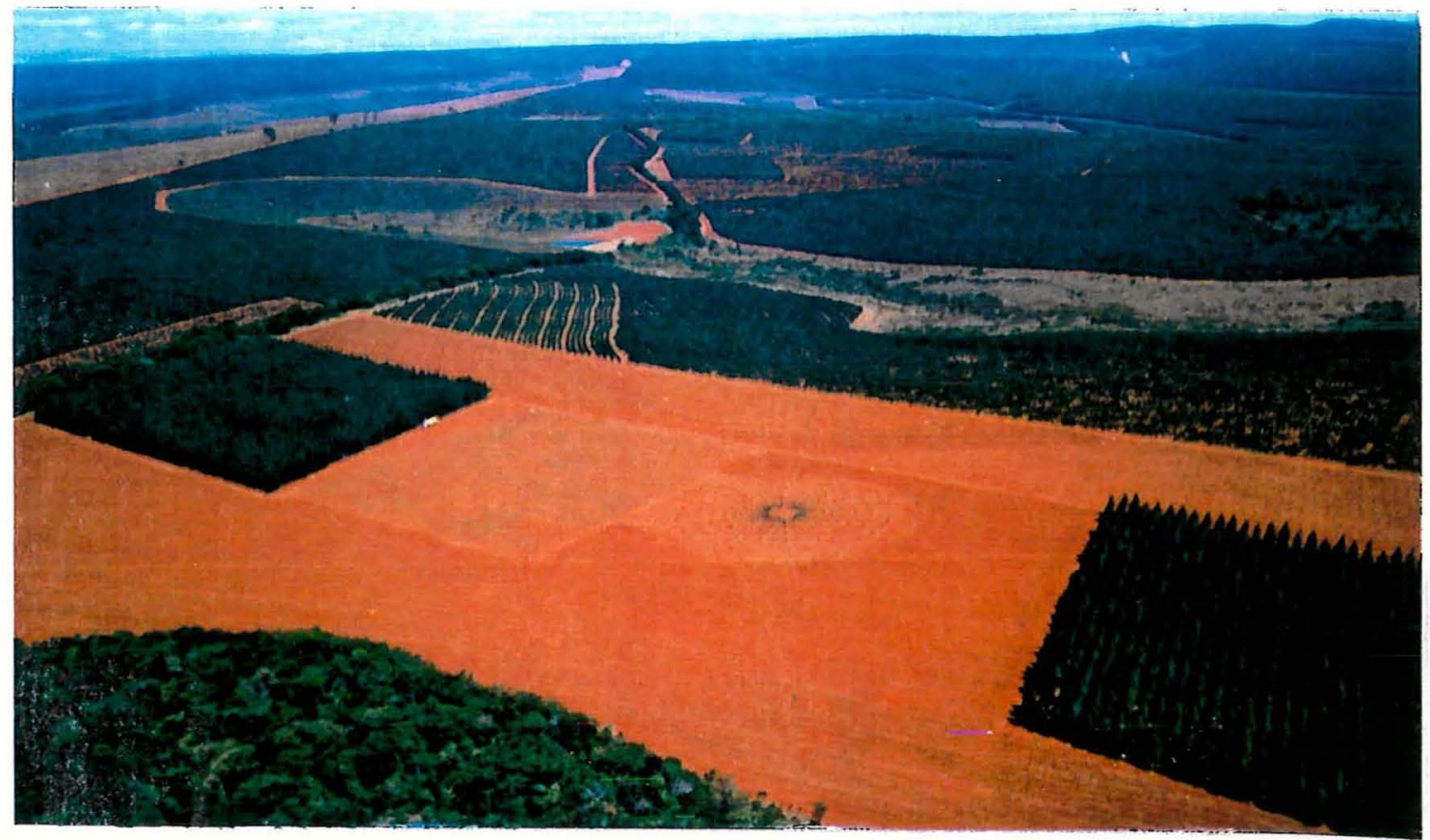

FIGURA 33. Vista aérea dos experimentos de espaçamento para E.dunnii com delineamentos em blocos casualizados (à esquerda) e sistemático tipo "leque" (à direita), aos 3 meses de idade (escala aproximada 1:5000).

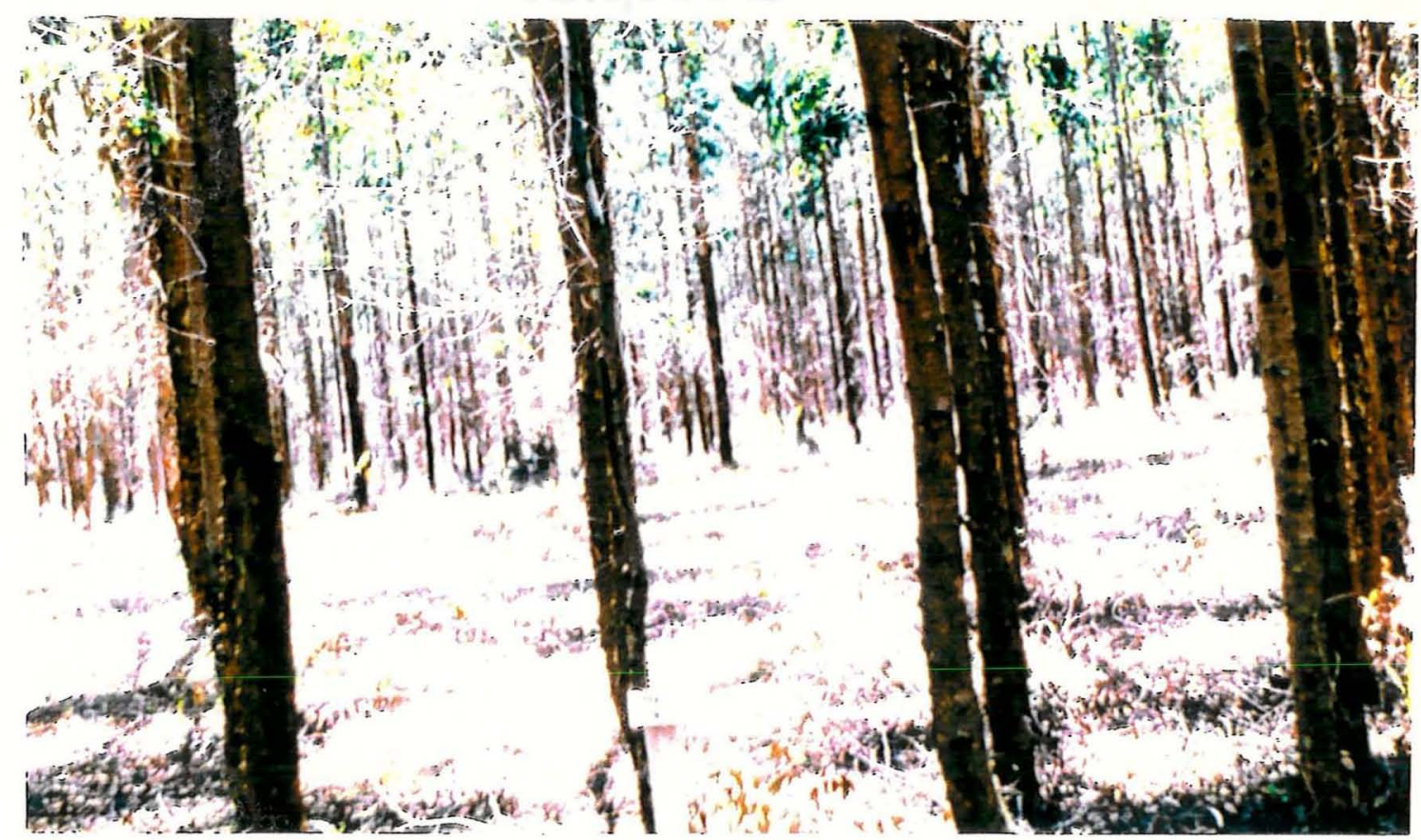

FIGURA 34. Vista, do centro para a periferia, do experimento em delineamento sistemático tipo "leque" aos 48 meses de idade, tendo ao fundo as parcelas do delineamento em blocos casualizados. 